\title{
RECEPCIÓN HISTÓRICA DE LA MÚSICA ECLESIÁSTICA DE JOSEPH HAYDN EN LOS ARCHIVOS MUSICALES CATEDRALICIOS DE LA COMUNIDAD VALENCIANA*
}

\author{
José Aparisi Aparisi \\ Conservatorio Superior de Música de Valencia
}

\begin{abstract}
Resumen:
Hasta donde conozco, no se ha realizado hasta la fecha un estudio sobre la recepción de la música, particularmente en lo referido al repertorio litúrgico — en latín — de Joseph Haydn, en los principales centros de producción musical eclesiástica de la Comunidad Valenciana. La primera fuente con música de Haydn datada en Valencia, en 1789, en plena actividad compositiva del músico de Rohrau - la parte para el órgano de la "Grosse Orgelsolomesse" ("Gran Misa para solo de órgano")—, aparece en Valencia sólo tres años después de la composición de Die sieben letzten Worte unseres Erlösers am Kreuze ("Las Siete últimas Palabras de Nuestro Salvador en la Cruz"), fruto del encargo que hiciera la Hermandad de la Santa Cueva de Cádiz al compositor. Por lo demás, el número de atribuciones de composiciones, equivocadamente adjudicadas a Joseph Haydn es, seguramente en el campo de la música de iglesia, mucho mayor que en otros géneros, lo que ofrece un amplio e interesante campo sobre el cual poder investigar.
\end{abstract}

* Este artículo corresponde al tercer capítulo de mi Trabajo de Investigación, -en cinco volúmenes-, titulado La recepción de la música eclesiástica de Franz. Joseph Haydn en los archivos catedralicios de la Comunidad Valenciana: sus fuentes (Universidad Politécnica de Valencia, 2004-2005), dirigido por el Dr. Antonio Ezquerro Esteban, quien ha aconsejado publicar ahora este trabajo con vistas a que los nuevos datos, ahora recopilados y ordenados, ayuden a re-situar la música haydniana en el contexto valenciano y español - y éstos, en relación al contexto internacional- . No he pretendido agotar el tema, sino apenas apuntalarlo, localizando fuentes y detectando materiales espurios, sirviendo como punto de partida para futuras investigaciones. [Este estudio, que parte básicamente del análisis de los fondos documentales de las catedrales de Valencia, Segorbe y Orihuela, y de la Iglesia del Patriarca, a cuyos responsables archiveros agradezco las facilidades dadas para mi investigación, se complementa con las tablas comparativas que se aportan en el trabajo académico mencionado (vol. I, pp.129-149), donde pueden cotejarse las fuentes conservadas y estudiadas de la Comunidad Valenciana, con las referencias aportadas por el catálogo de Hoboken y las ediciones del "Haydn-Institut" de Colonia; también puede verse ahí la relación del resto de copias "históricas" de las que se tiene noticia, a nivel internacional, y comparar los íncipits musicales correspondientes, así como obtener otro tipo de información adicional: copias transportadas, variantes en las instrumentaciones, diferentes dataciones, etc.]

This article is included in the third chapter of my dissertation, -in five volumes-, The Reception of Franz Joseph Haydn's Church Music in the Cathedral Archives of the Valencian Community: Sources (Universidad Politécnica de Valencia, 2004-2005), supervised by Dr. Antonio Ezquerro Esteban, who advised me to publish this piece of work intending for the new details, collected and arranged, to help relocate Haydn's music in the Valencian as well as the Spanish context -in connection with the international context. I have no intention whatsoever of exhausting the subject. I just intend to lay the foundations, by locating sources and identifying spurious material, for future research. [The present study began with the analysis of the document collections in the cathedrals of Valencia, Segorbe and Orihuela, and those in the church of the Patriarca in Valencia, and it is completed by the comparative tables provided in the above mentioned dissertation (vol.I, pp. 129-149), where it is possible to compare the sources preserved and studied in the Valencian Community with the references in Hoboken's catalogue and the editions of the "Haydn-Institut" in Cologne, Germany. There is also a list of the rest of historical copies internationally known and it is therefore possible to compare the corresponding musical incipits as well as to obtain any other additional information (transposed copies, instrumentation variants, different datings, etc.). I must say I am extremely grateful to the people in charge of the cathedral archives in Valencia, Segorbe and Orihuela for their help and kindness]. 
Palabras clave:

Joseph Haydn, música eclesiástica, Comunidad Valenciana, recepción clasicismo vienés, datación fuentes, manuscritos e impresos musicales.

\begin{abstract}
:
(The Historical Reception of Joseph Haydn's Church Music in the Cathedral Archives of the Valencian Community)*. As far as I know, no research has been done so far on the reception of Joseph Haydn's music, particularly that concerning the liturgical repertoire, in Latin, in the main centres of production of church music in the Valencian Community. The first source with music by Haydn, dated in Valencia in 1789, when the musician's composing activity was at its best — the organ part of the "Grosse Orgelsolomesse" ("Great Organ Solo Mass")_, appears in Valencia only three years after he composed Die sieben letzten Worte unseres Erlösers am Kreuze ("The Seven Last Words of our Saviour on the Cross") commissioned to Haydn by the Hermandad of the Santa Cueva in Cadiz. On the other hand, the number of compositions wrongly attributed to Joseph Haydn is, in all probability, much higher when it comes to church music than any other genre, which offers a wide and interesting field to study.
\end{abstract}

Keywords: prints.

Joseph Haydn, church music, Valencian Community, Viennese classicism reception, source dating, manuscripts and musical

A lo largo de su vida, Joseph Haydn escribió música perteneciente al rito católico, a saber, misas, el Stabat Mater, antífonas marianas, pequeñas composiciones de iglesia — graduales, ofertorios, motetes-, Las Siete Palabras, dos Te Deum, oratorios... Siendo España un país católico, tiene sentido que parte de la producción de Joseph Haydn haya llegado a la península. Y llegó antes y en mayor profusión que, por ejemplo, la de su compatriota Wolfgang Amadeus Mozart.

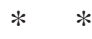

$*$

Para analizar la presencia e impacto de la música del compositor Franz Joseph Haydn en el territorio que comprende la actual Comunidad Valenciana, el primer paso es roturar los archivos objeto de estudio. Fruto de este vaciado, he localizado, además de las composiciones de que trataré, otras dos, de las que, a pesar de que queden fuera de los límites auto-impuestos, "sensu stricto" (pues la primera no es obra de nuestro compositor, sino de su hermano Michael, y la segunda, no es religiosa), ofreceré una somera descripción, habida cuenta su posible interés y relación con las obras religiosas a estudiar.

En los archivos musicales catedralicios de la Comunidad Valenciana, se encuentran catalogadas diferentes obras musicales de la familia Haydn, tanto de música sacra, como de cámara. Concretamente, de Michael Haydn, de quien su hermano Joseph pensaba que la música religiosa era muy superior a la suya ${ }^{1}$, se encuentra en el archivo del Real Colegio-Seminario de Corpus Christi de Valencia un

1 Rosen, Charles: El estilo clásico Haydn, Mozart, Beethoven. Madrid, Alianza Música, 1999, p. 421. 
ofertorio, Domine Deus salutis meae ("Señor, Dios de mi salvación”) en partitura impresa en París por "Nicou-Choron et Canaux", cuya primera página dice:

\author{
"DOMINE DEUS SALUTIS MEAE \\ OFFERTOIRE a 4 Voix en Canon \\ Par G. MICHEL HAYDN."
}

\author{
N. C. 272. \\ Nicou-Choron et Canaux \\ Boulevard St Denis 14."
}

La partitura, impresa en formato vertical o francés (de 34,2 x 26,4 cm.) $)^{3}$, [pp. 16-24], sin signatura, pero con número de registro 2.581, y en la tonalidad de Sol Mayor, está conformada para cuatro voces solistas, coro, y órgano. Forma parte de La Lire Sacrée, una colección ${ }^{4}$ que reúne impresos de varios autores, encuadernada con tapas de color marrón, y cuyo lomo dice: "MÚSICA RELIGIOSA". En el reverso de la cubierta se lee: "BIBLIOTECA / del M. I. Sr. D. Vicente Ripollés Pérez / Canónigo de la Catedral y antiguo Maestro / de Capilla en la de este R. Colegio de / Corpus Christi de Valencia / (†19 marzo 1943) / Legada por el mismo a este R. Colegio / AÑO 1939".

Así, pues, este impreso perteneció a Vicente Ripollés Pérez (*1867; †1943), quien fuera maestro de capilla del Real Colegio-Seminario de Corpus Christi de Valencia entre el 6 de julio de 1895 y el 28 de agosto de $1902^{5}$, el cual lo entregó como legado al archivo en 1939. En dicho archivo sólo se conserva esta obra de Michael Haydn.

Por su parte, Michael Haydn finalizó la composición del ofertorio Domine Deus salutis meae el 23 de agosto de 1803 en Salzburgo. La partitura autógrafa se conserva en la Biblioteca Nacional de Viena, con la signatura 19083/2.

Según parece, la obra fue publicada por primera vez en Viena en 1925 (¡nada menos que 122 años después de su composición!), en transcripción de Anton Maria Klafsky, en los Denkmäler der

2 Agradezco la revisión de los textos litúrgicos en latín, así como sus respectivas traducciones, al Dr. Josep Pavia i Simó, Científico Titular del csic y Canónigo Prefecto de Música de la Catedral de Barcelona.

3 Para el presente artículo, utilizaré las siglas de archivos y bibliotecas, instrumentación, dataciones, y en general, descripción física de materiales documentales, etc., adoptadas por RISM-Internacional. [Vid.: GonzÁlez Valle, José V.; EzQuerro, Antonio; Iglesias, Nieves; Gosálvez, C. José; y Crespí, Joana, eds.: Répertoire Internacional des Sources Musicales. Normas Internacionales para la Catalogación de Fuentes Musicales Históricas. (Serie A/II, Manuscritos Musicales, 1600-1850). Madrid, Arco/Libros, 1996. -RISM Bibliothekssigel. Gesamtverzeichnis. (Bearbeitet von der RISM-Zentralredaktion und den RISMLändergruppen). Munich, G. Henle, 1998].

4 "LA LIRE SACRÉE Catalogue des Morceaux Publié à Paris chez Colombier, Sucé de A. Petit, Rue Vivienne, 6, au coin du Passage Vivienne". [LA LIRA SAGRADA Catálogo de Fragmentos Publicado en París por Colombier, Sucesor de A. Petit, Calle Vivienne, 6, a la vuelta del Pasaje Vivienne]. Valencia.

5 Agradezco esta información a Vicente Ferrer Granell, organista del Real Colegio-Seminario de Corpus Christi de 
Tonkunst in Österreich ("Monumentos de la Música en Austria"), entonces bajo la dirección de Guido Adler, y reimpresa en Graz, en 1960, donde esta composición figuraba, además, —en una reproducción inalterada de la edición de Viena de 1925-, junto a una antífona, nueve graduales y un motete del mismo compositor, todo lo cual puede localizarse hoy día en la edición completa de sus obras, XXXII/1, tomo 62, [pp. 9-27] ${ }^{6}$.

Como aportación al estudio de la obra de este autor, podemos decir, por tanto, que el impreso francés custodiado en el Real Colegio-Seminario de Corpus Christi de Valencia supone la versión más antigua que se conoce a nivel internacional, entre las editadas, en la cual no se había reparado hasta el momento presente. Sin duda, dado que el impreso valenciano lleva como número de plancha7 “N. C. 272." (iniciales correspondientes al editor francés Nicou Choron) y sello de caucho entintado con la firma rubricada de autentificación "Nicou-Choron et Canaux", ha de ser, forzosamente, anterior al impreso mencionado — datado en 1925-, puesto que Stephano Louis Nicou-Choron $(* 1809 ; \uparrow 1886)$, y su colaboración empresarial con Canaux produjo actividades editoriales en París, entre 1834 y 1837 — cuando fueron socios-. Más concretamente, podría decirse con relativa certeza que este impreso podría datarse desde después de 1836, y hasta febrero de $1840^{8}$

La obra consta de dos secciones: la primera es canónica — un canon a cuatro voces_- y la segunda (Coro) un Alleluia. Llama la atención que el impreso francés anota la expresión italiana "attaca subito l'Allegro" al final de la primera sección, indicación carente en la edición de Viena. Ambos impresos presentan algunos detalles más que los diferencian. Así, el impreso francés que se conserva en Valencia (más antiguo que el publicado en Viena), indica al principio "Andante cantabile", y en el choeur, "Allegro"; mientras que en la partitura de la edición vienesa empieza en un tempo "Allegretto", y en el Chorus, "Presto". Hay que considerar no obstante que el impreso francés se trata de un arreglo o adaptación para cuatro voces solistas, Coro y órgano (para facilitar acaso la mayor y más sencilla

6 Ch. Sherman y T. D. Thomas han preparado un catálogo temático de las obras de Michael Haydn (J. M. Haydn. A Chronological Thematic Catalogue of His Works. Stuyvesant/Nueva York, 1993), destinado a sustituir a los anteriores, a cargo de L. H. Perger (obras instrumentales: "Thematisches Verzeichnis der Instrumentalwerke Michael Haydns", en Michael Haydn. Instrumentalwerke, I. Viena, 1907, XV-XXIX [= DTÖ XIV/2] y A. M. KLAFSKY (obras religiosas: "Thematisches Verzeichnis der Kirchenwerke von Michael Haydn", en Michael Haydn. Kirchenwerke. Viena, 1925, V-VIII [= DTÖ XXXII/1]). [Agradezco esta información al Dr. Robert von Zahn, del Joseph Haydn-Institut de Colonia].

7 Por "número de plancha" se entiende el número de orden atribuido a las planchas metálicas originales utilizadas para la impresión. Este número, que puede estar constituido por una combinación de letras (a menudo, las iniciales del editor), de cifras (generalmente, el número de registro o de control interno que un editor adjudicaba a cada composición musical que salía de su taller), o de símbolos (rasgos identificadores de diferentes tiradas, colecciones o fondos editoriales, etc.), podía recoger, incluso, el nombre completo de un editor, de suerte que hacía las veces de identificador del editor, de sus tiradas, e incluso podía servir para conocer en qué fechas tal o cual editor imprimió determinados títulos. Usualmente, este número de plancha se imprimía en la parte baja (o pie) de la página de música ya impresa, y generalmente, aunque no siempre, en una posición centrada. Como queda dicho, estos números de plancha son de gran utilidad hoy día, pues permiten identificar las planchas a partir de las cuales una edición fue impresa, así como, a menudo, datar las composiciones, dado que los impresores utilizaban estos números a manera de registro de salida de sus propias producciones.

8 Agradezco esta información a la profesora Anik Devriès-Lesure, en su carta del 11 de febrero de 2005. (Entre 1834 y 1837, Nicou-Choron y Canaux estuvieron asociados, mientras que, a partir de 1837, -y hasta 1842- retomó el fondo Canaux, quien, al parecer, continuó utilizando las anteriores iniciales empleadas como números de plancha). 
difusión de la obra, o incluso tal vez con algún motivo comercial), a partir de la partitura que Michael Haydn compuso originalmente para cuatro voces solistas, Coro, orquesta y órgano, distribución esta última que sí respeta la edición de Viena.

La segunda obra relacionada con las localizadas actualmente en la Comunidad Valenciana, aunque quede fuera, obviamente, del espectro litúrgico que nos hemos marcado, son los Seis cuartetos, Op. 17 (Hob.III:25-30) de Joseph Haydn, si bien sólo nos ha llegado la partichela de violín segundo, impresa por Sieber en 1773 en París. Esta partichela, valiosísima - aparte su contenido - por su carácter tan temprano de recepción dentro del ámbito hispánico, se encuentra en el archivo de la Catedral de Orihuela, con la signatura 61 (mide 30,2 x 22,5 cm.) ${ }^{9}$. José Climent la cataloga como "Quinteto en Mi mayor, Op. 17"10. Pero se trata sin duda de un error. En lugar de Quinteto, lo que encontramos en la fuente conservada son seis cuartetos, y la expresión "Mi mayor" debe hacer referencia únicamente al primero de ellos que está en esa tonalidad, pues, de hecho, los seis cuartetos se anotan en las siguientes tonalidades: $1^{\circ}$ en Mi Mayor (Hob.III:25); $2^{\circ}$ en Fa Mayor (Hob.III:26); $3^{\circ}$ en Mi bemol Mayor (Hob. III:27); $4^{\circ}$ en Do menor (Hob.III:28); $5^{\circ}$ en Sol Mayor (Hob.III:29); y $6^{\circ}$ en Re Mayor (Hob.III:30). La obra mencionada, obviamente, no es religiosa, a pesar de que se encuentra en el archivo de música de una de las catedrales objeto de interés, y de que, probablemente, habría formado parte del repertorio que los músicos de aquella capilla habrían interpretado en las funciones catedralicias correspondientes. Su título dice:

"SIX / QUATUORS / A deux Violino Alto et Basse / Composés / PAR / G. HAYDEN / OEUVRE 17. ${ }^{\text {e }}$ Prix. 9. ${ }^{\text {th }} /$ A. PARIS / Chez / Le S. ${ }^{r}$ Sieber Editeur de plusieurs ouvrages de Musique / rue S. ${ }^{t}$ Honoré à l'hotel d'aligre près la Croix du trahoire / Et aux adresses ordinaries. A Lyon. Chez M. ${ }^{\mathrm{r}}$ Castaud / place de la comedie / A. P. D. R. / Gravé par M. ${ }^{\mathrm{d}}$ Sieber" ${ }^{11}$.

La obra puede consultarse en el tomo de la edición completa de las obras de Joseph Haydn, XII/2 (pp.84-98), publicado por el Joseph Haydn-Institut de Colonia bajo la dirección de Georg Feder, editado por él mismo e impreso en 1963 en la editorial G. Henle de Munich. La numeración de los cuartetos que aparece en esta edición corresponde al orden cronológico de creación por parte del compositor: $1^{\circ}$ Fa Mayor (Hob.III:26); $2^{\circ}$ Mi Mayor (Hob.III:25); $3^{\circ}$ Do

9 Según el catálogo temático de nuestro compositor, se encuentran ejemplares en Austria (en cinco localidades), Alemania (dos), Italia (una) y Estados Unidos (una). No se menciona ejemplar alguno conservado en España, lo que incrementa sin duda el valor de esta partichela oriolana. (Véase: Новокеn, Anthony van: Joseph Haydn. Thematisch-bibliographisches Werkverzeichnis. Band I: Instrumentalwerke. Mainz: B. Schott’s Söhne, 1957, pp. 383-387).

10 Climent, José: Fondos Musicales de la Región Valenciana, IV. Catedral de Orihuela. Valencia, Institución Alfonso el Magnánimo, 1986, p. 145.

11 SEIS / CUARTETOS / A dos Violines, Viola y Bajo / Compuestos / POR / G. HAYDEN / OBRA 17 / Precio 9 $/$ th París / En casa del Señor Sieber Editor de varias obras de Música / calle $S^{t}$. Honoré en el hotel de Aligre cerca de la Croix du trahoire / Y en las direcciones ordinarias. En Lyon. En casa del Señor Castaud / plaza de la comedia / A. P. D. R. / Grabado por la Señora Sieber. 
menor (Hob.III:28); 4 Re Mayor (Hob.III:30); 5 Mi bemol Mayor (Hob.III:27); y $6^{\circ}$ Sol Mayor (Hob.III:29) ${ }^{12}$.

En cualquier caso, sorprende gratamente comprobar que un impreso dado a luz cuando Joseph Haydn apenas contaba con 41 años de edad —en 1773 — ha llegado hasta Orihuela ${ }^{13}$.

A pesar de que se trata de una obra que se ha conservado incompleta, naturalmente, el hecho de que se encuentre en una localidad como Orihuela — provincia de Alicante — un impreso salido de las prestigiosas oficinas del taller parisino de Jean-Georges Sieber $(* 1738$; $\uparrow 1822$; primer editor de numerosas obras de Haydn y Mozart - junto al sobresaliente Artaria y algún otro editor menor-, entre otros muchos relevantes compositores de la época), nos ofrece una valiosa perspectiva del alto nivel alcanzado por la capilla musical oriolana, que al parecer se abastecía, contemporáneamente, de la mejor música del panorama internacional, indicador sin duda de la puesta al día y actualización en lo relativo a la literatura del momento disponible por parte de sus músicos.

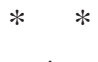

$*$

\section{Las obras de música litúrgica de Joseph Haydn en Valencia, Segorbe y Orihuela ${ }^{14}$ :}

\section{Missa in Es In honorem Beatissimae Virginis Mariae "Grosse Orgelsolomesse"}

Según un análisis de papel del autógrafo de la Missa In honorem Beatissimae Virginis Mariae "Grosse Orgelsolomesse" (Misa en honor de la Santísima Virgen María "Gran Misa para solo de órgano") (Hob. XXII:4), ésta debió de escribirse entre 1767 y 1769 (siendo la fecha más probable la última citada), en la tonalidad de Mi bemol Mayor ${ }^{15}$. Al parecer, el comentario de Anthony van Hoboken en el tomo II, página 74 de su célebre catálogo, se basa en un error ${ }^{16}$, pues Hoboken señala ahí que los responsables de la editorial Artaria, en el año 1835, fraccionaron en varias partes — posiblemente para su mejor comercialización— la partitura de la Misa (Hob.XXII:4). Y una de dichas partes incluía el movimiento del Kyrie, que habría sido vendido por Artaria a un aristócrata ruso apellidado Balsch, según supone Hoboken, basándose para ello en la biografía de Haydn a cargo de Carl Ferdinand Pohl $(* 1819 ; \dagger 1887)^{17}$. Sin embargo, esto sucedió, no con la Gran Misa para solo de órgano, sino con el autógrafo de la Missa Sanctae Caeciliae (Hob.XXII:5).

12 Agradezco esta información al Dr. Armin Raab, responsable de la dirección del trabajo que está realizando el Joseph Haydn-Institut de Colonia desde 1998.

13 En el ejemplar oriolano, la música se extiende de la página 2 a la página 15; se trata de un ejemplar cosido; en la parte superior central de la página 15 , se encuentra arrancado un trozo de papel.

14 Se han dispuesto las obras atendiendo a un orden cronológico (de creación de las obras por parte del compositor).

15 Según me indica el Dr. Robert von Zahn, del Joseph Haydn-Institut de Colonia, en su carta del 25 de junio de 2004.

16 Según aprecia nuevamente el citado Dr. Robert von Zahn. Vid.: HовокEN, Anthony van: Thematisch-bibliographisches Werkverzeignis Band II: Vokalwerke. Mainz: B. Schott's Söhne, 1971.

17 Pohl, Carl Ferdinand: Joseph Haydn. Tomo I (Berlín, 1875), p. 260 y nota al pie 50; y Tomo II (Leipzig, 1882), p. 38. 
En cualquier caso, la música que encontramos en tierras valencianas puede cotejarse en el tomo de la edición completa de las obras de Joseph Haydn, XXIII/1b (pp. 1-104), publicado por el Joseph Haydn-Institut de Colonia, editado por James Dack y Marianne Helms e impreso en 1999 en la editorial G. Henle de Munich ${ }^{18}$.

De esta Misa existen tres copias en la Comunidad Valenciana, que son las que se encuentran en los archivos del Real Colegio-Seminario de Corpus Christi ("Patriarca") de Valencia, y las catedrales de Segorbe y Orihuela, respectivamente. Ninguna de ellas se halla referenciada en el catálogo temático de Hoboken, ni en la obra editada por el Joseph Haydn-Institut de Colonia, como tampoco otras copias manuscritas conservadas en España que he podido localizar, ubicadas en el Santuario de Aránzazu (Guipúzcoa), o en el Archivo de Música de las Catedrales de Zaragoza (en copia muy temprana, del año 1785), Mondoñedo (Lugo) y Valladolid ${ }^{19}$.

La fuente documental — copia manuscrita - hallada en el Real Colegio-Seminario de Corpus Christi de Valencia, bajo la signatura $\mathrm{H} \mathrm{8/1} \mathrm{y} \mathrm{2,} \mathrm{fue} \mathrm{realizada} \mathrm{por} \mathrm{diferentes} \mathrm{copistas,} \mathrm{a} \mathrm{juzgar} \mathrm{por} \mathrm{la}$ diversa caligrafía que presenta, y en fechas distintas. Se conservan las siguientes partichelas: Tiple de $1^{\circ}$ Coro — con un trozo de papel pautado añadido que incluye algunos compases y dice: "Solo suplente del Contralto" (que podría datarse aproximadamente hacia el tercer tercio del siglo XIX)—, Alto de $1^{\circ}$ Coro, Tenor de $1^{\circ}$ Coro, Baxo de $1^{\circ}$ Coro, Tiple de $2^{\circ}$ Coro $^{20}$, Tiple $2^{\circ}$ de $2^{\circ}$ Choro, Alto de $2^{\circ}$ Coro, Tenor de

18 Sobre las fuentes conservadas con música de Joseph Haydn, pueden verse algunas reflexiones en: - WeBSTER, James: "The Falling-Out between Haydn and Beethoven: the Evidence of the Sources", en Beethoven Essays: Studies in Honor of Elliot Forbes, (L. Lockwood y P. Benjamin, eds.). Cambridge Massachussets, 1984, pp. 3-45.

19 El catálogo de Hoboken (op. cit.) menciona copias en Austria (en 19 archivos y bibliotecas), Alemania (en diez), República Checa y Eslovaquia (tres), Italia (una), Bélgica (una) y Suiza (una). El Joseph Haydn-Institut menciona copias en Austria (en 25 archivos y bibliotecas), Bélgica (una), Suiza (tres), República Checa (ocho), Alemania (diecisiete), España (dos), Gran Bretaña (una), Hungría (cuatro), Croacia (una), Italia (cuatro), Polonia (dos), Suecia (una), Eslovaquia (cuatro), Estados Unidos (una). Para las copias españolas citadas, véase: BAGüÉs, Jon: Catálogo del antiguo Archivo Musical del Santuario de Aránzazu. [San Sebastián], Caja de Ahorros Provincial de Guipúzcoa, 1979, p. 124 (Ms.192). Vid. también: Trillo, Joám y Villanueva, Carlos: El Archivo de Música de la Catedral de Mondoñedo. Salamanca, Publicaciones de Estudios Mindonienses, Número X, Imprenta Kadmos, 1993, p. 373: "Misa ligera, en Re, a 8 v." (partitura copiada por Santiago Pérez de Castro en 1815), signatura "47/5" y n ${ }^{\circ}$ de registro "1504". Por su lado, la fuente de Valladolid, identificada como "Misa a 8 v.", se ha localizado a través de los ficheros del antiguo Instituto Español de Musicología, hoy Departamento de Musicología del csic en Barcelona (se menciona como signatura E-VAc; 2/9, y se ofrece el íncipit del Kyrie). Para la fuente del Archivo de Música de las Catedrales de Zaragoza, se ha consultado el catálogo informatizado (agradezco la información al Dr. Antonio Ezquerro): dicha fuente se conserva en partitura manuscrita, anotada para S, A, T, B; vl 1, 2, b; ob 1, 2; cor 1, 2; lleva por título: "Missa A 4 Voces, / Con trompas oboeses Violines y Bajo. / D / S . Joseph Ayden, Ma ${ }^{\text {tro }}$. de Capilla / del Emperador Josef II de Lorena Año 1785". [Sobre esta última composición, vid.: EzQuerro EsteBAn, Antonio: "Misa a 4 voces, con trompas, oboeses, violines y bajo de D.n Joseph Ayden, Maestro de Capilla del Emperador Josef II de Lorena Año 1785”, en El espejo de nuestra historia: La diócesis de Zaragoza a través de los siglos. Zaragoza, Zaragoza Cultural / Instituto para el Estudio y la Conservación del Patrimonio / Editorial Edelvives (Ayuntamiento de Zaragoza- Arzobispado de Zaragoza), 1991, p.326; y EzQuerro Esteban, Antonio: "Grosse Orgel-solo-messe de Haydn", en La Música en los Archivos de las Catedrales de Aragón. (A. Ezquerro Esteban, L. A. González Marín y J. V. González Valle, eds.). Zaragoza, Caja Inmaculada (Imp. Estudio Versus), 2008, p.276 y 153-155].

20 De manera característica, esta parte anota al final del Gratias las palabras "Vuelve pronto" indicadoras al ejecutante de que ha de girar rápidamente el papel para seguir leyendo sin interrupción (en lugar de anotar los habituales "Volti presto", "V. P.", "Volti Subito" o "V. S."), y culmina con la frase "Fin / Ad maiorem Dei Gloriam.". 
$2^{\circ}$ Coro $^{21}$, Baxo de $2^{\circ}$ Coro (triplicado) ${ }^{22}$, Violín $1^{\circ}$ (duplicado) $^{23}$, Violín $2^{\circ}$ (duplicado) —ambas copias de una segunda mano- Contrabajo (duplicado) - una copia que correspondería a una segunda mano, datable en torno a 1807, y otra copia que podría datarse hacia el tercer tercio del siglo XIX-, Baxón — también copia de una segunda mano-,Trompa $1^{\mathrm{a}}$, Trompa $2^{\mathrm{a} 24}$, y Órgano Obligado (triplicado) ${ }^{25}$.

Una de las tres partichelas de órgano muestra la mano sin duda más antigua, pues se data en 1789 - fecha en que actuaba como maestro de capilla del Real Colegio-Seminario de Corpus Christi, Antonio Montesinos (*Carlet -Valencia-, 03.07.1754, †Valencia, 07.08.1822)—, lo que acrecienta enormemente su valor, pues querría decir que su copia sería posterior únicamente en veinte años a la composición autógrafa de su autor, e implicaría por tanto una recepción muy temprana de su obra en tierras valencianas, de manera semejante a lo que ya se ha constatado con otros casos conocidos de fuentes conservadas en España ${ }^{26}$.

La portada de esta partichela, acaso la más antigua del juego conservado, dice así:

"Organo Obligado / Missa a 4 Duplicado. Con / Viols, Obueses, Trompas, y Orgo / Obligado. / De Don Jph Ayden / Año de 1789”.

Hay otras dos copias más manuscritas de la parte de órgano obligado, que podrían datarse, una, en torno a 1837 (según el "Borrador" que asimismo se conserva, el cual presenta características similares de copia), y la otra, aproximadamente, en el tercer tercio del siglo XIX.

Por otra parte, las partichelas vocales del archivo del Real Colegio-Seminario de Corpus Christi van fechadas en $1807^{27}$, una fecha muy temprana (sólo treinta y ocho años posterior a la composición

21 Anota al final del Credo las palabras "Vuelve Pto al Sanctus." (vid. partichela de Tiple de $2^{\circ}$ Coro), y termina escribiendo "Copiome Juan Thomas Pagasartundua.".

22 Una de las partichelas de Bajo de $2^{\circ}$ Coro posiblemente sea de una segunda mano, aunque el formato de dicha partichela es el mismo que el de las restantes; por otra parte, todo el juego de partichelas parece copiado a partir de un impreso, a juzgar por las enmiendas que hace el copista.

23 Una de las partichelas de violín $1^{\circ}$ es de una segunda mano, anota al final del Kyrie "V. S. al Gloria" y al final del Sanctus "V. ti al Benedictus", además de otras indicaciones que individualizan su copia, como por ejemplo, "V. S.".

24 Las copias de ambas trompas podrían corresponder al tercer tercio del siglo XIX; la portada de la trompa $1^{\text {a }}$ (pues la trompa $2^{\mathrm{a}}$ no tiene), mantiene la carátula (común a todo el juego de partichelas), la cual no se ha terminado de copiar.

25 Las partichelas manuscritas anotan diez pentagramas por cada cara, y presentan unas medidas de $26,5 \times 18,5 \mathrm{~cm}$. Una de las partichelas de contrabajo contiene nueve pentagramas por cada cara, y mide $32,2 \times 22,5 \mathrm{~cm}$. La partichela de trompa $2^{\mathrm{a}}$ anota once pentagramas por cada cara. La partichela de órgano del año 1789 presenta cinco sistemas por cada cara, con unas medidas de $25 \times 18,5 \mathrm{~cm}$. Las restantes dos partichelas de órgano contienen seis sistemas por cada cara-midiendo $26 \times 18,3 \mathrm{~cm}$. - , o cinco sistemas por cada cara -midiendo 31,5 x $21,3 \mathrm{~cm}$. -, respectivamente.

26 Me refiero aquí, por ejemplo, a la copia del Stabat Mater conservada en la Seu de Manresa (1781), a la de la Catedral de Albarracín (1783), a la Grosse Orgelsolomesse del Archivo de Música de las Catedrales de Zaragoza, datada en 1785, o al encargo de Las Siete Palabras para la Hermandad de la Santa Cueva de Cádiz (alrededor del año 1785), de cuya música se conservan abundantes copias tempranas repartidas por España y Latinoamérica, sólo por mencionar algunos casos. [Para la copia manresana, véase: BALLús I CASÓLIVA, Glòria: La música a la col-legiata basílica de Santa Maria de la Seu de Manresa: $1714-1808$. (Dades documentals per a la seva reconstrucció amb una aproximació al repertori litúrgic conservat). Tesis doctoral (director, A. Ezquerro), Universitat Autònoma de Barcelona, 2004. Para la copia de Albarracín, vid.: GonZÁlez Marín, Luis Antonio: "Stabat Mater de Haydn", en La Música en los Archivos de las Catedrales de Aragón. (A. Ezquerro Esteban, L. A. González Marín y J. V. González Valle, eds.). Zaragoza, Caja Inmaculada (Imp. Estudio Versus), 2008, p.275].

27 Aventurando una posible datación para estos materiales conservados, podría decirse que las partichelas instrumentales (exceptuando las partes de trompa $1^{\mathrm{a}}$ y trompa $2^{\mathrm{a}}$, una partichela de contrabajo y las tres fuentes conservadas de la parte de órgano obligado), también podrían haber sido realizadas, por diferentes copistas, en torno a 1807, aproximadamente. 
original, y asimismo todavía en vida de Joseph Haydn), de donde podría inferirse (dado que la obra continuó ejecutándose con el paso de los años, y sacándose nuevas copias —al menos, en 1789 y 1807-), no sólo una temprana recepción de su música, sino incluso un cierto éxito, y su rápida absorción y asimilación a los repertorios eclesiásticos valencianos.
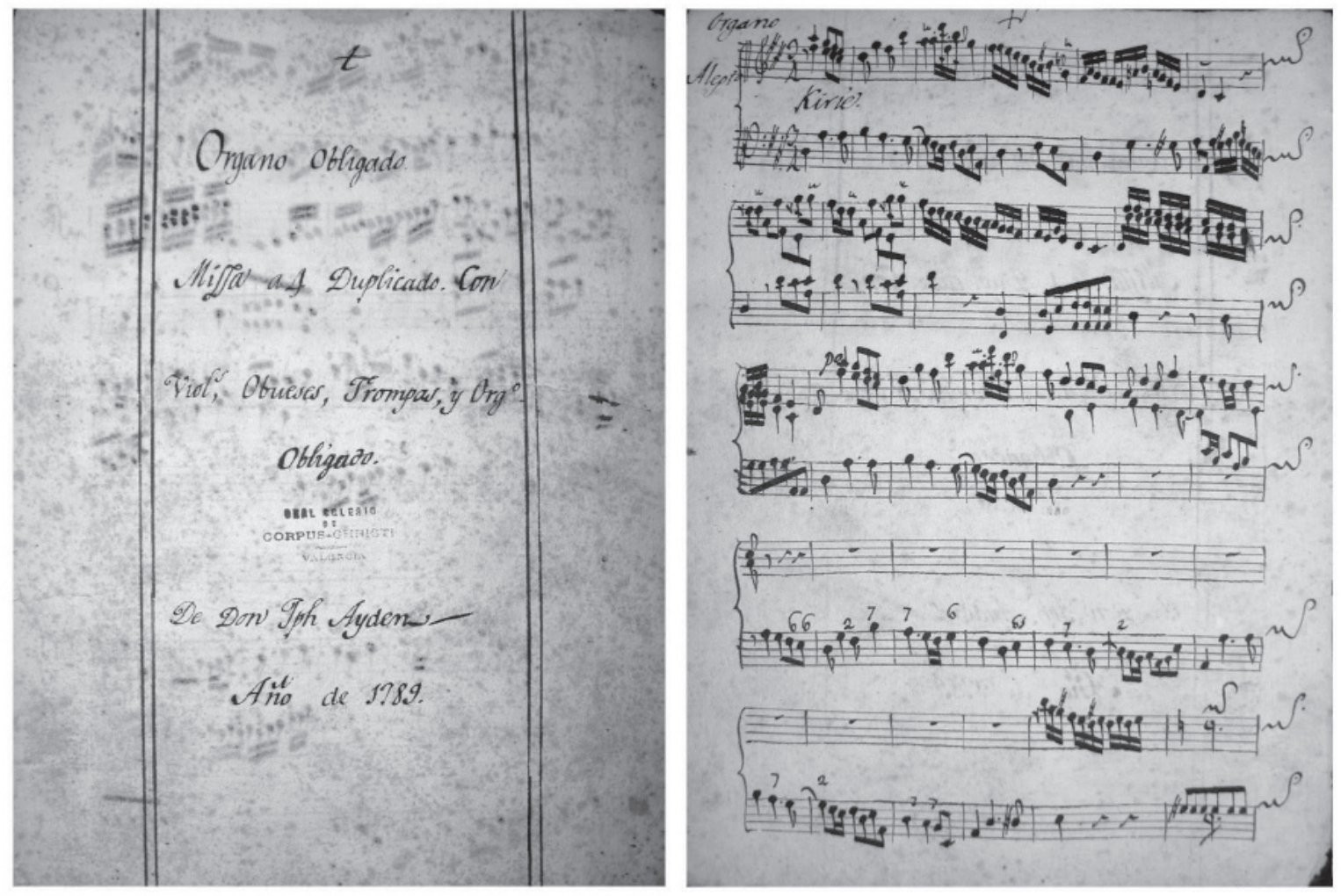

Figura 1: Grosse Orgelsolomesse [1767-1769]. Portada (a) y comienzo musical (b) de la partichela manuscrita para órgano, "Año de 1789". Real Colegio-Seminario de Corpus Christi "Patriarca”, de Valencia (E-VAcp), signatura $\mathrm{H} 8 / 1$ y 2.

Tanto es así, que esta obra continuó interpretándose durante largo tiempo en el Real ColegioSeminario de Corpus Christi; así lo atestigua al menos una anotación manuscrita de uno de sus infantes de coro - y luego afamado compositor-, que escribió en la contraportada de la parte vocal para Tiple del Coro 20 lo siguiente: "Vicente Lleó / 1884". Curiosamente, este niño cantor — que rondaría para entonces los catorce años - era la misma persona que más tarde se convertiría en el célebre compositor Vicente Lleó Balbastre, bien conocido por algunas de sus producciones musicales para la escena, como por ejemplo la opereta "La corte de Faraón" (1910). Obviamente, aunque luego destacara en 
otras modalidades de la composición bien alejadas del ámbito litúrgico, con una formación y una experiencia musical como las adquiridas en el seno de la escolanía del Colegio del Patriarca, donde había tenido oportunidad de interpretar algunas de las mejores obras de la literatura musical universal, como la presente Misa de Haydn, sólo cabían esperar buenos resultados en cuanto a su conocimiento y hábil manejo de la escritura vocal y orquestal ${ }^{28}$.

De manera semejante, se encuentran algunas otras anotaciones por parte de los infantes de coro, que nos ofrecen pistas valiosas para realizar un seguimiento de la "recepción" continuada — que puede fijarse por tanto documentalmente entre 1866 y 1881 de manera bastante frecuente, casi siempre en el mes de agosto - de la obra de Joseph Haydn en la capilla valenciana del Colegio del Patriarca: en las partichelas para Tiple, tanto del Coro $1^{\circ}$ como del Coro $2^{\circ}$, encontramos, entre dibujos y garabatos, algunas referencias como las siguientes, síntoma inequívoco de su interpretación músico-práctica por parte de la capilla del Real Colegio-Seminario de Corpus Christi, en horario tanto de mañana, como por la tarde y noche:

"Lo ha hecho Vicente / Plaza y Tos dia / 3 de Diciembre 1866 / [y sobreañadido: "y lo repasó el dia 23 de Agosto de 1881"]". - "Lo ha hecho Vicente Plaza y Tos dia 3 / de Diciembre 1870".

"Lo ha hecho José Sánchez / dia 12 de Agosto de 1879 / por la noche".

"Lo hecho Juan Lasa / [y sobreañadido: "y por la tarde"] / y Briva dia 12 de / Agosto de 1879 por la noche".

"Lo ha hecho Antonio Pastor y Pichó / dia 1213 de Agosto de 1879". —“"Lo ha hecho Antonio Pastor y Pichó / dia 23 de Agosto de 1881". — "Lo ha hecho / Antonio Pastor / y Pichó siendo mayor".

"Lo cantó a Vicente Benavent / Lo canto año 1880". // "Lo a hecho Vicente / Benavent / 1881". — "Lo ha hecho Vicente / Benavet y Llorens / dia / 19 de Agosto año 1881".

"Lo ha hecho Vicente Lleó / dia 19 Agosto 1880". — "Vicente Lleó dia 22 de Agosto de $18[?] "$.

"Lo ha hecho Francisco Zurita y Miralles por la Mañana". - "Francisco Zurita / y Miralles".

El copista de las partichelas vocales es un tal Juan Thomas Pagasartundua, que anota su nombre al final de la partichela del Tenor de $2^{\circ}$ Coro y del Bajo de $2^{\circ}$ Coro:

28 Vicente Lleó Balbastre (*Torrent —Valencia—, 19.11.1870; †Madrid, 28.09.1922) ingresó como niño de coro en el Real Colegio-Seminario de Corpus Christi de Valencia a los siete años, donde estudió composición con Juan Bautista Plasencia Aznar y el Tenor de aquella capilla musical, Lamberto Alonso. A los 13 años (sólo unos meses antes de anotar su nombre en la partichela de la presente Misa de Haydn) compuso ya un salmo Dixit Dominus a 7 voces, de modo que continuó escribiendo obras religiosas en el ámbito de la capilla musical del Colegio hasta que le mudó la voz. (Cfr.: GaLbis López, Vicente: "Lleó Balbastre, Vicente", en Diccionario de la Música Española e Hispanoamericana. Madrid, sGAE, 2000, vol. 6, pp. 950-953). [Como veremos enseguida, todavía se encuentran otras anotaciones de Lleó como niño cantor, que indicarían que habría cantado esta Misa de Haydn al menos cuatro años antes, en 1880, cuando él apenas contaría nueve años de edad]. 
"Copiome Juan Thomas Pagasartundua día 12 de Julio del año de 1807. Ad maiorem Dei gloriam".

Existen tres portadas para la copia manuscrita de la partitura, a razón de una para cada uno de los tres ejemplares conservados:

1) "BORRADOR, / de la Misa / à cuatro y à ocho del / Maestro D. JOSE HAYDEN / 1837."

Se trata de una copia posterior en sesenta y ocho años posteriores a su composición original, en tiempo en que era maestro de capilla José Morata (*Geldo -Castellón-, 27.01.1769; †Valencia, 04.02.1840).

2) "Para regir la Misa del Maestro Ayden".

Sin indicación expresa de fecha alguna, la datación de este ejemplar podría fijarse, aproximadamente, hacia el primer tercio del siglo XIX.

3) "MISA / A / 4. Y 8. / DE / D. JOSE AYDEN.".

Sin indicación expresa de fecha alguna en la fuente, podríamos no obstante aventurar una datación en torno al último cuarto del siglo XIX. Esta última fue encuadernada y está sin terminar de copiar. Mide 30,5 x 21,5 cm., y en su margen superior derecho lleva pegada una etiqueta con el número 9.

La escritura de la fuente conservada recoge las partes vocales según su notación antigua, con clave de Do en primera para la voz de Tiple, clave de Do en tercera para la voz de Contralto y clave de Do en cuarta para la voz de Tenor, conservándose algunos signos gráficos hoy en desuso, como los silencios de máxima, longa o breve para los compases de espera. La tonalidad, aparece aquí transportada un semitono bajo tal vez con la finalidad de acomodarse a las tesituras de los cantores de la capilla valenciana (donde posiblemente, al cantarse con niños en fase de aprendizaje, u hombres — capones o falsetistas—, no se alcanzaran con holgura los registros más agudos, quizá interpretados en otras formaciones europeas, acaso más especializadas, con mujeres o cantores profesionales de ámbito no estrictamente eclesial — procedentes de agrupaciones civiles o aun operísticas o teatrales-).

Sea como fuere, la instrumentación de la fuente valenciana no se ajusta con la edición completa de las obras de Joseph Haydn: faltan aquí los papeles del corno inglés 1 y 2, y en contrapartida se incluye un "baxón", lo que nos habla bien a las claras de la "adecuación" que las capillas eclesiásticas españolas, y valencianas, debían hacer para poder adaptar el repertorio internacional a sus propias características y recursos técnicos y humanos (dado que el corno inglés era un instrumento generalmente ausente de tales capillas en la época, mientras el bajón era un instrumento todavía omnipresente en muchas de ellas, incluso por encima del fagot, seguramente por su papel fundamental para acompañar el canto). Por lo demás, algunas de las partichelas conservadas, especialmente bien copiadas, recogen el título de la obra de manera abreviada, como por ejemplo en el siguiente caso: 
“Organo Obligo. / Misa á 4 y 8. / Tono en Re. / Del Mtro. D. Jose Ayden.”.

Por su lado, en el archivo de la Catedral de Segorbe se conserva otra copia manuscrita de esta misma Misa — sólo las partichelas, de 22 × 31,5 cm.— ${ }^{29}$, con signatura 33/7, la cual tiene en común con el ejemplar de la Iglesia del Patriarca la tonalidad (Re Mayor), encontrándose por tanto también transportada un semitono bajo al original de Joseph Haydn, posiblemente por las mismas razones aducidas que en el caso anterior (el tono de Mi bemol era inusual para una Misa, y además, la iban a interpretar unos cantores de capilla eclesiástica media española, para cuyos empleos muy posiblemente no se exigiría como requisito fundamental — aunque sí deseable — disponer de un registro vocal particularmente amplio).

Se conservan las siguientes partichelas: Tiple $1^{\text {ro }}$ Coro, Alto $1^{\text {ro }}$ Coro, Tenor $1^{\text {ro }}$ Coro, Baxo $1^{\text {ro }}$ Coro, Tiple $2^{\circ}$ Coro, Alto $2^{\circ}$ Coro, Tenor $2^{\circ}$ Coro, Baxo $2^{\circ}$ Coro, Violín $1^{\text {ro }}$, Violín $2^{\circ}$, Contrabaxo, Obue $1^{\mathrm{o}}$ (duplicado), Oboe $2^{\mathrm{do}}$, Trompa $1^{\text {ra }}$, Trompa $2^{\text {da }}$, Figle (duplicado), Org. ${ }^{\circ}$ Obligado (duplicado) y Organo 2 do.

La portada de la partichela del Tiple de Coro $1^{\circ}$ dice:

“Missa á $4{ }^{\text {tro }}$ y á 8. / Con Violines, Oboesses, Trompas / y Organo Obligado / Aiden”.

Por un lado, el papel sobre el que se copia esta obra tiene una apariencia bastante antigua, presentando además las partes síntomas evidentes de haber sido profusamente utilizadas; por otro, el hecho de escribir "Ayden" es propio por otra parte de época temprana, posiblemente muy a comienzos del siglo XIX. Si se hubiera de aventurar una datación, ésta podría fijarse, con todas las cautelas, entre 1820 y 1870 , aproximadamente.

El material conservado contiene mayores efectivos que la edición completa de las obras de Joseph Haydn, sin duda por su empleo "práctico" a lo largo de los años: se añade un segundo órgano, y un figle (evidentemente sobreañadido con posterioridad), el cual, además, se anota un tono bajo. Nuevamente, faltan algunas partichelas, en este caso las de dos cornos ingleses, aunque se incluyen, en contrapartida, dos oboes, que ejecutan lo mismo que originalmente estaba destinado a dichos cornos ingleses. (Y esto, sin duda, para suplir la carencia de estos instrumentos en la capilla castellonense, la cual se solventa con los instrumentos disponibles más cercanos o semejantes a los concebidos por el compositor).

Las partichelas conservadas fueron realizadas por distintos copistas. De los dos ejemplares manuscritos que se conservan de la parte de oboe, el más antiguo, "Obue 10", podría datarse hacia primeros del siglo XIX, mientras que el más moderno, "Oboé $1^{\text {o”, }}$ podría ser ya de finales de dicha centuria.

29 Curiosamente, las partichelas para las voces del Coro primero (seguramente, los solistas), así como para el órgano obligado, presentan una página a manera de portada, mientras que el resto (voces del segundo Coro e instrumentos, incluyendo también el órgano segundo), carecen de dicha portada, lo que da cuenta de una cierta jerarquización y preponderancia de los protagonistas músicos para la ejecución práctica de la obra. 
De las partichelas de órgano obligado, el primer ejemplar ofrece indicaciones de registración: "Organo obligado Clarines. Cad ${ }^{\text {ta }}$ flautados de Aydem." 30 ; se trata de una copia bastante antigua (datable hacia principios del siglo XIX, aproximadamente), muy abigarrada y con un cifrado muy abundante, que en algunos lugares incluso se encuentra realizado. El otro ejemplar de Org. ${ }^{\circ}$ Obligado es más moderno, ya de finales del siglo xIX aproximadamente, habiendo por lo tanto una diferencia temporal entre ambos ejemplares.

En cuanto al ejemplar conservado para el segundo órgano, podría datarse hacia comienzos del siglo XIX (primer tercio, aproximadamente).

Por lo demás, hay dos ejemplares más modernos, con una "atemporal" parte para el figle, ambas ya de finales del siglo XIX. Precisamente, se trata aquí de unas partes realmente valiosas para nuestro objetivo, pues nos pueden ofrecer interesantes pistas de cómo se realizó a lo largo del tiempo y en cada momento (a menudo, siguiendo las modas que imperaban en cada ocasión), la "recepción" de la música de Haydn con participación vocal en las capillas eclesiásticas valencianas. En este sentido, los papeles para dicho figle conservados, anuncian ya una curiosa concepción y disposición, pues anotan indicaciones tales como: "Figle y hace la parte del Acomp. ${ }^{\text {to }}$ continuo y parte de la trompa $2^{\text {da" }}$, o en el segundo ejemplar, "Figle = Acomp. ${ }^{\text {to }}$ Continuo = Misa de Ayden Punto bajo.".

El juego completo de partichelas manuscritas, según todos los indicios, entró en los fondos de la catedral con el legado de José Perpiñán y Artíguez (*Segorbe, 24.01.1863; †Id., 01.05.1928) -maestro de capilla de la Catedral de Segorbe-, legado que se donó a la catedral en 1928 tras su fallecimiento ${ }^{31}$. En dicho inventario, en el folio 16v., dentro del apartado Obras en rústica con los números 13 y 14, se cita la Misa $n^{o} 9$ de Haydn ${ }^{32}$. De otra parte, sorprende que en este caso, esta obra (posiblemente ajena a la capilla valenciana de Segorbe en el siglo XVIII), retornara precisamente a la seo segorbina, pues, de no haber pertenecido con anterioridad a ella, hubiese sido mucho más lógico que el manuscrito hubiera ido a parar a cualquier otro centro — al ayuntamiento, o a algún archivo general público valenciano—, si bien no hay que desdeñar el hecho de que Vicente Perpiñán conociera su primitivo origen y propietario,

30 Según David Wyn Jones, en la "Schöpfungsmesse" ("Misa de La Creación”) (Hob.XXII:13), compuesta en 1801, "In the section of the Credo dealing with the mystery of the Virgin Birth, the "Et Incarnatus est", Haydn had it in mind to depict the Holy Spirit in the centuries-old manner, as a dove. In music such an image was often represented by a flute. Since Haydn did not have a player at his disposal he gave the line to the organ indicating that it should be played on a flute stop, the only time in his career that the composer indicated an organ registration. According to one anecdote Haydn "darted like a weasel" to the organ to play the part himself, much to the amusement of the performers". [En la sección del Credo que trata el misterio del nacimiento de la Virgen, el "Et incarnatus est", Haydn tenía en mente representar el Espíritu Santo como se hacía siglos atrás, como una paloma. En música, tal imagen se solía representar con una flauta. Puesto que Haydn no contaba con un flautista, dio la parte al órgano, indicando que se debía tocar en un registro de flauta. Fue ésta la única vez en su carrera que el compositor indicó un registro de órgano. Existe una anécdota según la cual Haydn "corrió como una comadreja" hacia el órgano para tocar esa parte él mismo, para divertimento de los intérpretes]. (Wyn JonEs, David: Oxford Composer Companions: Haydn. Nueva York, Oxford University Press, 2002, p. 355). Véase el tomo de la edición completa de las obras de Joseph Haydn, XXIII/4 [p. 98], publicado por el Joseph Haydn-Institut de Colonia bajo la dirección de Georg Feder, editado por Irmgard Becker-Glauch e impreso en 1967 en la editorial G. Henle de Munich.

31 Sobre este músico, y su sobrino Vicente, asimismo compositor, vid.: Climent, José: "Perpiñán”, en Diccionario de la Música Española e Hispanoamericana. Madrid, SGAE, 2001, vol.8, pp.722-723.

32 Agradezco esta información al profesor Magín Arroyas Serrano. 
o bien, que, simplemente, por su vinculación a dicha seo segorbina, hubiera creído lo mejor, depositar la fuente en su archivo.

Por su parte, la copia manuscrita de la partitura que se encuentra en la Catedral de Orihuela, sin signatura, pero con número de registro 893, está en la tonalidad original de Mi bemol Mayor. El manuscrito - que mide 22,5 x 31,2 cm. —, fue encuadernado con tapas de cartón, en cuya primera hoja dice: "Libro $1^{\mathrm{o}}$ ". En el margen superior derecho de la primera hoja de papel pautado, figura la siguiente inscripción:

"El Servicio de Defensa de Patrimonio Artístico Nacional deposita en la Catedral de Orihuela este manuscrito de música religiosa. Alicante 20 Abril 1940”.

Al parecer, según se observa en el documento referido, el mencionado "Servicio de Defensa de Patrimonio" habría destinado estos materiales en primer lugar a la "Colegiata de Alicante", nombre reescrito en el manuscrito - aunque legible_- y sustituido por el destino final en el que hoy se encuentra, la "Catedral de Orihuela" ${ }^{3}$.

Seguidamente hay una firma. En el sello quedó estampado:

“Recuperación Patrimonio Artístico Nacional - Servicio Militar”.

El 28 de marzo de 1940 se constituía, en el salón de sesiones del Excmo. Ayuntamiento, el Patronato Artístico de la Ciudad de Orihuela. Este Patronato se creó con la finalidad de "la conservación, fomento y estudio de la riqueza artística, arqueológica y documental de la ciudad y su comarca" ${ }^{34}$. La firma que aparece en la portada de la copia manuscrita de la partitura, debió pertenecer a algún funcionario del Servicio Nacional de Recuperaciones. De ello se deduce que siendo el Patronato el único existente en la provincia de Alicante, digamos dependiente del Ministerio de Educación y por tanto de la Comisaría General del Servicio de Defensa del Patrimonio Artístico Nacional, fuera esta ciudad la receptora, así como lo fue de algunas obras que se enviaron directamente del Museo del Prado. Teniendo en cuenta que en aquellas fechas (1940) Orihuela era la sede Episcopal, hoy compartida (desde 1966) con Alicante, es lógico que esta partitura "recuperada" la enviaran a la catedral ${ }^{35}$.

33 Este suceso, acaso pudo ser motivado por un relativamente extendido malentendido, en el sentido de identificar las capitales de provincia (concretamente aquí, Alicante) con las capitales de diócesis eclesiásticas (Orihuela), a pesar de que éstas no siempre son coincidentes, como es aquí el caso, que se habría subsanado sin duda al entrar en contacto con los responsables eclesiásticos del patrimonio en la diócesis oriolana.

34 Este Patronato fue creado gracias a Luis Almarcha Hernández (*Orihuela, 14.10.1887; †León, 17.12.1974), que fuera - con la sola interrupción de la Guerra Civil Española- Vicario General del Obispado desde 1924 hasta el 4 de enero de 1944, fecha del fallecimiento del entonces obispo de Orihuela, Francisco Javier Irastorza Loináz. [Precisamente, el mismo Luis Almarcha fue consagrado obispo en Orihuela ese mismo año de 1944 (el 24.09.1944), posesionándose de su nueva prelatura como obispo de León el 28.10.1944, cargo en el que cesó el 04.04.1970. (Agradezco esta información a Felipe Boixo González, vicesecretario canciller del Obispado de León)].

35 Agradezco esta información a Manuel Soriano Murcia, secretario del Patronato Artístico de Orihuela. 
Al observar el manuscrito se ven unos guioncitos ("= = = =") para la separación de las sílabas, que, si bien se trataba en la época de una manera relativamente frecuente de indicar la separación de sílabas en líneas diferentes, no deja de ser un rasgo caligráfico algo peculiar, y que incluso podría llevarnos a pensar, por analogía, a la vista de otras fuentes manejadas, en que posiblemente se tratara de una copia a partir de un impreso - posiblemente italiano o francés, aunque más probablemente italiano-, (donde este tipo de signos se empleaba con frecuencia para señalar los pasajes melismáticos sobre una misma sílaba), o bien de una copia manuscrita extranjera.

A lo largo de la composición hay indicaciones para instrumentos que no aparecen en el reparto inicial. Por ejemplo, en la parte de los clarines se anota "Corno $1^{\mathrm{o}}$ ", y en la parte del primer corno inglés se anota "Clarinetti $1^{\circ} / 2^{\circ}$ " (compás 42 del Kyrie). La parte del órgano está, unas veces realizada, y otras, sólo cifrada; es concertante, y la mano derecha se escribe en clave de Do en primera, prueba fehaciente de que es antiguo. En este caso, aventurar una datación fiable resulta muy arriesgado: por un lado, los trazos caligráficos inducirían a relacionar esta fuente con un tiempo cercano a los comienzos del siglo XIX (entre 1810 y 1840, aproximadamente); por otro, dado que el aprendizaje caligráfico se hacía generacionalmente y podía llegar a tener una larga perdurabilidad en el tiempo, acaso su fecha de copia pudiera retrotraerse hasta una época ya muy posterior (finales del siglo XIX)...

El copista de esta fuente tardía anotó en italiano la instrumentación, a la cual agregó dos trompetas y timbal ${ }^{36}$.

\section{Stabat Mater}

Joseph Haydn compuso su Stabat Mater (Hob.XXbis) en 1767 en la tonalidad de Sol menor. La obra puede consultarse en el tomo de la edición completa de sus obras, XXII/1 [pp. 1-103], publicado por el Joseph Haydn-Institut de Colonia, editado por Marianne Helms y Fred Stoltzfus e impreso en 1993 en la editorial G. Henle de Munich.

De esta composición existen también tres copias manuscritas en la Comunidad Valenciana, que son las que se encuentran en los archivos de las catedrales de Valencia, Segorbe y Orihuela.

36 Según David Wyn Jones, "Additional parts for trumpets (clarini) and timpani are transmitted by copies of the mass from the mid-1770s and later, including one made by Haydn's copyist Joseph Elssler senior, which suggests that these parts might be authentic. Other variations in instrumentation, such as the substitution of oboes, clarinets, or violas for the cors anglais, have no authentic basis". [Partes adicionales para trompetas (clarini) y timbales se han transmitido a través de copias de la Misa que datan de mediados de la década de 1770 y otras posteriores, incluida una hecha por el copista de Haydn, Joseph Elssler padre (†26.10.1782), lo que indica que estas partes podrían ser auténticas. Otras variaciones en la instrumentación, tales como la sustitución de oboes, clarinetes, o violas por cornos ingleses, no tienen una base auténtica]. (Wyn Jones, David: Oxford Composer Companions: Haydn. Nueva York, Oxford University Press, 2002, p. 240). 
El catálogo temático de Hoboken no las menciona ${ }^{37}$, como tampoco otras copias manuscritas que se han conservado en España y que he podido localizar, ubicadas en los archivos musicales del Santuario de Aránzazu (Guipúzcoa), Catedral de Astorga (León), Biblioteca de Cataluña (Barcelona), Catedral de Gerona, Monasterio de Guadalupe (Cáceres), Archivo de Palacio en Madrid, Catedral de Mondoñedo (Lugo), Catedral de Salamanca, Catedral de Santiago de Compostela, Catedral de Segovia y Catedrales de Zaragoza (dos copias). La obra editada por el Joseph Haydn-Institut de Colonia menciona copias manuscritas conservadas en España, pero no las que se encuentran en los archivos musicales catedralicios de la Comunidad Valenciana ${ }^{38}$.

La copia manuscrita hallada en la Catedral de Valencia —en partitura, con tapas de cartón forradas en piel, de 20,2 x 27,6 cm., y en cuyo lomo dice "STABAT"-, bajo la signatura 154/2, es la única que contiene una portada, cuyo título dice así:

“STABAT / Con Violines, Oboes, Viola y Bajo / del Sr Josef Hayden. / para el uso / de D. ."

La bonita copia es antigua, y como sacada de algún impreso o de alguna otra partitura manuscrita. Probablemente fuera copiada a partir de una partitura impresa, a juzgar por los compases que deja en

37 El catálogo de Hoboken (op.cit.) menciona copias en Alemania (en doce archivos y bibliotecas), Austria (once), Italia (cinco), Estados Unidos (dos), Gran Bretaña (dos), República Checa y Eslovaquia (dos), Bélgica (una), Dinamarca (una), España (una), Holanda (una), Hungría (una) y Suiza (una). Por su parte, el Joseph Haydn-Institut menciona copias en Alemania (en veinticuatro archivos y bibliotecas), Italia (dieciocho), Austria (dieciséis), República Checa (seis), España (cinco), Estados Unidos (cuatro), Polonia (cuatro), Hungría (tres), Francia (dos), Gran Bretaña (dos), Holanda (dos), Suiza (dos), Bélgica (una), Dinamarca (una), Eslovaquia (una), Portugal (una) y Suecia (una).

38 Para las copias españolas citadas, véase: Pedrell, Felip: Catàlech de la Biblioteca Musical de la Diputació de Barcelona, Vol. II. Barcelona, Palau de la Diputació; Vilanova i la Geltrú, Oliva Impressor, 1909, p. 326. BARRADo, Arcángel: Catálogo del Archivo Musical del Monasterio de Guadalupe. Badajoz, Diputación Provincial de Badajoz, Institución de Servicios Culturales, 1945, p. 89. Civil i Castellví: "La capilla de música de la catedral de Gerona (siglo xviII", en Anales del Instituto de Estudios Gerundenses, 29 (1968-1969), pp. 131-188. López CaLo, José: Catálogo Musical del Archivo de la Santa Iglesia Catedral de Santiago. Cuenca, Instituto de Música Religiosa, 1972, p. 315. BAgüÉs, Jon: Catálogo del antiguo Archivo Musical del Santuario de Aránzazu. [San Sebastián], Caja de Ahorros Provincial de Guipúzcoa, 1979, p. 124 (Ms. 194). Climent, José: Fondos Musicales de la Región Valenciana, I. Catedral Metropolitana de Valencia. Valencia, Instituto de Musicología, Institución Alfonso el Magnánimo, Diputación Provincial de Valencia, 1979, p. 206. García FraILE, Dámaso: Catálogo Archivo de Música de la Catedral de Salamanca. Cuenca, Instituto de Música Religiosa, Diputación Provincial de Cuenca, 1981, p. 214. Stevenson, Robert: Haydn's Iberian World Connections, en: Inter-American Music Review, 4 (1982), p. 19. Climent, José: Fondos Musicales de la Región Valenciana, III. Catedral de Segorbe. Segorbe, Publicaciones de la Caja de Ahorros y Monte de Piedad de Segorbe, 1984, p. 130. Álvarez Pérez, José María: Catálogo y Estudio del Archivo Musical de la Catedral de Astorga. Cuenca, Instituto de Música Religiosa, Diputación Provincial Cuenca, 1985, p. 36. CLiment, José: Fondos Musicales de la Región Valenciana, IV. Catedral de Orihuela. Valencia, Institución Alfonso el Magnánimo, 1986, p. 144. López Calo, José: La Música en la Catedral de Segovia. Segovia, Diputación Provincial de Segovia, 1989, p. 402. PerIS Lacasa, José, dtor.: Catálogo del Archivo de Música del Palacio Real de Madrid. Madrid, Patrimonio Nacional, 1993 , p. 318. Trillo, Joan; y Villanueva, Carlos: El Archivo de Música de la Catedral de Mondoñedo. Salamanca, Publicaciones de Estudios Mindonienses, $n^{\circ}$ X, Imprenta Kadmos, 1993, p. 373: obra con la signatura "47/7” y no de registro "1506". RIFÉ, Jordi: "Notas sobre el fons musical de l'arxiu de la catedral de Girona", en Actes del I Congrés Català de la Música. Barcelona, 1994. Las fuentes citadas en Zaragoza son: E: Zac, D-0/3 (nº de antiguo inventario "616") [una partitura manuscrita de 154 páginas, siglo XVIII, para coro a 4 voces y orquesta: violines, violetta, oboes, bajo y acompañamiento; en Sol menor y compás de compasillo]; y $E$ : Zac,D-4/27, un juego completo de partichelas manuscritas, siglo XVIII, con la parte de las trompas añadida. [Agradezco las informaciones sobre las fuentes de Zaragoza al Dr. Antonio Ezquerro]. 
blanco, sin escribir los silencios. El copista denota pulcritud ${ }^{39}$. La portada, muy decorada, acaso copiada de algún grabado, incluye motivos vegetales y pájaros de reducido tamaño. Sin indicación expresa de fecha alguna en la fuente, podríamos no obstante aventurar una datación para este manuscrito en torno a 1810-1840, aproximadamente.

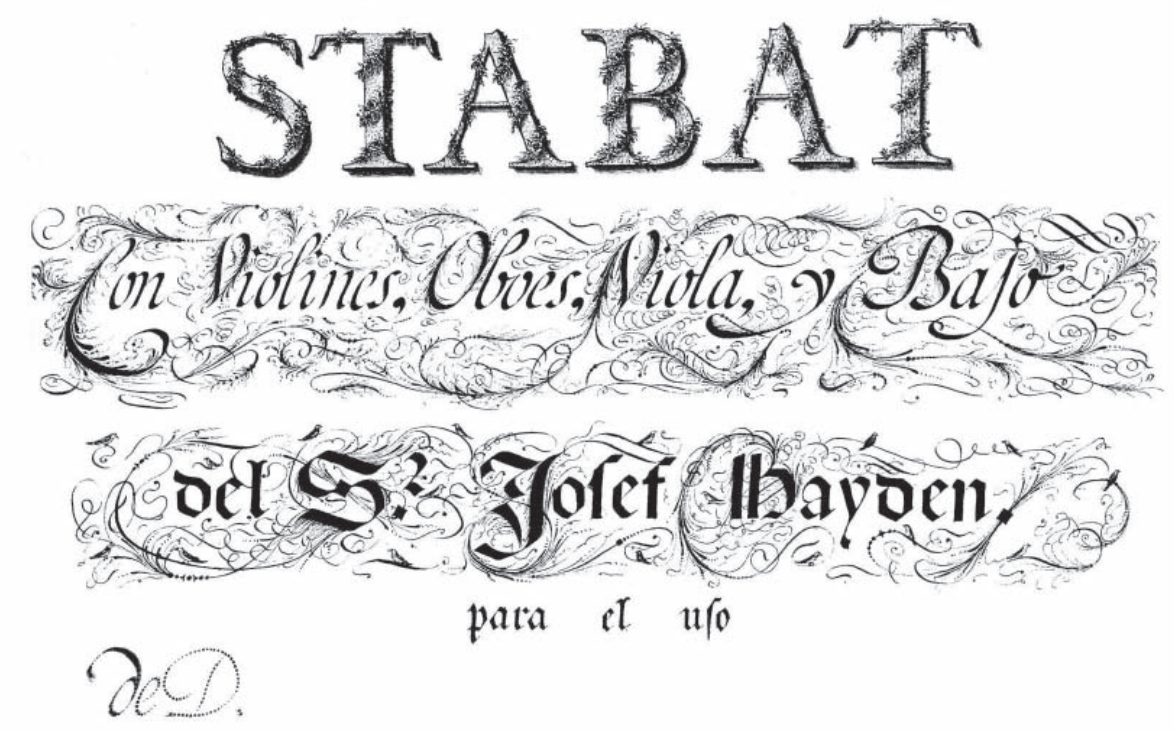

Figura 2: Stabat Mater [1767] —ms., portada partitura— de F. J. Haydn (Hob.XXbis). Archivo de Música de la Catedral de Valencia (E-VAc), signatura 154/2 (1810-1840).

Al cotejar esta fuente con el tomo de la edición completa de las obras de Joseph Haydn, se puede apreciar que la instrumentación de la fuente valenciana denota carencias al no contar con los dos cornos ingleses originales, si bien los dos oboes ejecutan lo que estaba destinado a tales cornos ingleses. (Seguramente para suplir la posible carencia de estos instrumentos en la capilla metropolitana valentina, adoptándose como solución la de los instrumentos más afines a los concebidos por el compositor). El título que figura en la portada dice que lleva bajo, refiriéndose al acompañamiento, que es el bajo continuo.

39 Por otra parte, este mismo copista incluye, en la aplicación del texto a la musicalización correspondiente, y en particular para indicar que sobre una misma sílaba ha de ejecutarse un pasaje melismático, unos pequeños signos caligráficos (" = = = "), como ya vimos en el caso del ejemplar oriolano de la "Grosse Orgelsolomesse", y que encontramos igualmente en el Te Deum de Joseph Haydn, impreso (muy posiblemente francés, a juzgar por las iniciales "D. et C." aparecidas como identificadoras de sus planchas), conservado en el Real Colegio-Seminario de Corpus Christi de Valencia. 


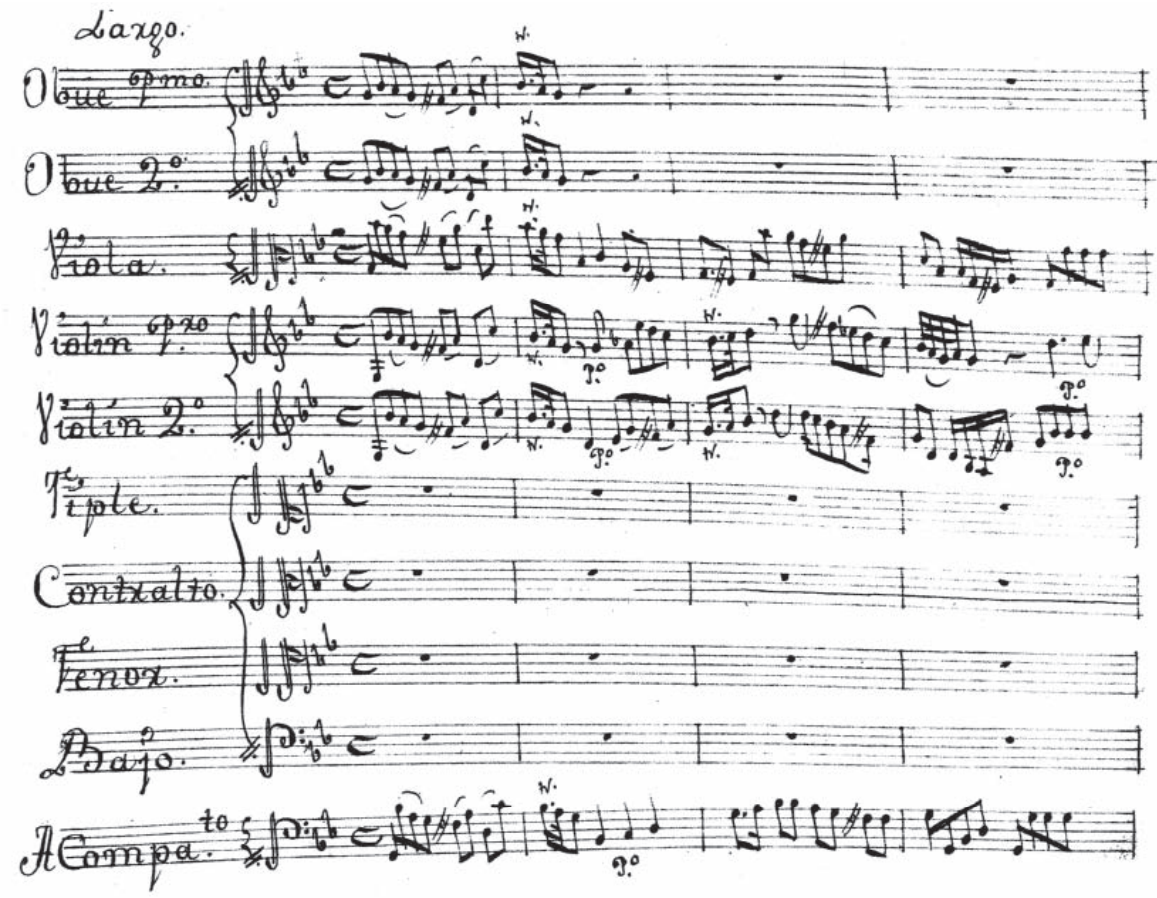

Figura 3: Stabat Mater [1767] —ms., inicio de la partitura— de F. J. Haydn (Hob.XXbis). E-VAc, signatura 154/2 (1810-1840).

En el archivo de la Catedral de Segorbe se conservan copias manuscritas de las partichelas, con la signatura 33/8. Son las siguientes: Tenor â 4, Bajo â 4, Violín Pro â 4, Violín $2^{\text {do }}$ â 4, Viola â 4, Oboe Pro, Oboe $2^{\text {do }}$, acompañamiento. En las partichelas del oboe $1^{\circ}$ y del oboe 2 do hay indicaciones en algunos pasajes para el corno inglés. Así por ejemplo, en el $O$ quam tristis et aflicta (Oh cuán triste y afligida), anota "Corno Ynglesi”, y en el Virgo virginum praeclara (Oh preclara Virgen entre las vírgenes) también "Corno Ynglesi". Estas partichelas manuscritas (de 22 x 31,5 cm.), según todos los indicios entraron en los fondos de la catedral con el legado de José Perpiñán y Artíguez (*Segorbe, 24.01.1863; †Id., 01.05.1928) — maestro de capilla de la catedral de Segorbe—, legado que se donó a la catedral en 1928 tras su fallecimiento ${ }^{40}$.

Al organizar las copias facilitadas pude comprobar que faltaban algunas partes, a saber: dos voces solistas (Soprano, Contralto), y dos voces de Coro (Soprano y Contralto).

Sin indicación expresa de fecha alguna, la datación de la fuente segorbina podría fijarse no obstante entre 1810 y 1840 , aproximadamente.

40 El Stabat Mater aparece en el inventario del legado, folio 11v., sin especificar el autor. (Agradezco esta información al profesor Magín Arroyas Serrano). 
La copia manuscrita de la partitura que se encuentra en la Catedral de Orihuela, bajo la signatura 12/3, fue realizada por Josef Aleyxandre ${ }^{41}$, siendo maestro de la capilla oriolana entre el 5 de noviembre de $1785^{42}$ y agosto de 1815, Joaquín López González. Dado que, según José Climent ${ }^{43}$, José Aleyxandre López se relacionó en torno al año 1791 con los capitulares de Orihuela, la copia manuscrita pudo ser realizada en el transcurso de los veinticuatro años que median entre 1791 y 1815 . O bien, estaríamos ante una copia realizada mucho antes, y que pudiera haber llevado consigo con la intención de emplearla en algún momento o situación concreta.

La copia está muy deteriorada. La tinta ha traspasado los papeles, de manera que resultan prácticamente ilegibles, aunque, a pesar de ello, todavía es posible determinar los instrumentos que participan en esta secuencia. El manuscrito presenta una cubierta de pergamino; los folios, de 21,7 x $31 \mathrm{cms}$., aparecen cosidos; la música se extiende del folio 1 al 55.

Las indicaciones para el reparto de las voces y de los instrumentos están anotadas en castellano. Tiene, no obstante, indicaciones en lengua italiana que hacen pensar que pueda tratarse de copias extraídas a partir de una fuente precedente.

En el éxplicit figura la firma rubricada del copista y propietario "Aleyxandre". El título diplomático [pie de la página 1] dice: "Stabat Mater A 4 (y â 8) de D." Josef Haydn; es de Josef Aleyxandre" [rubricado].

La instrumentación de la fuente oriolana no se ajusta con la edición completa de las obras de Joseph Haydn: en la copia manuscrita de la partitura faltan las partes del corno inglés 1 y 2, y se añaden dos flautas (que remedian la carencia de los dos cornos ingleses). En Stabat Mater dolorosa (Estaba la Madre dolorosa) incluye violonchelo; en $O$ quam tristis et afflicta dice Acom. ${ }^{\text {to }}$, y en Eia Mater, fons amoris (Oh Madre, fuente de amor) se lee Bajo, expresiones todas que hacen referencia al bajo continuo.

Se ha conservado la partichela manuscrita de violín primero (de 21,7 x 29,8 cm.), al parecer copiada por otra persona — se anota además en lengua italiana—, y de un impreso muy posiblemente extranjero - lo que se puede rastrear en la manera de escribir las "F" (mayúsculas) para indicar "forte", y las "p" (minúsculas) para indicar "piano", así como la mezcla de algunos términos italianos y castellanos, como por ejemplo "Volti sigue"-. En su portada, dice así:

"Violino Primo / Al Stabat â 4 / Haydn".

Sin indicación expresa de fecha alguna en la fuente, podríamos no obstante datar esta partichela entre principios del siglo xIX y 1830 ó 1840.

41 José Aleyxandre López fue maestro de capilla de la Catedral de Orihuela entre el 1 de septiembre de 1815 y el 4 de junio de 1832 .

42 No obstante, su nombramiento consta en 1789. (Véase: Climent, José: Fondos musicales de la Región Valenciana, Vol. III. Catedral de Segorbe. Segorbe, Publicaciones de la Caja de Ahorros y Monte de Piedad de Segorbe, 1984, p. 148).

43 Climent, José: Fondos Musicales de la Región Valenciana. IV. Catedral de Orihuela. Valencia, Institución Alfonso el Magnánimo, 1986, p. 28. 


\section{O Iesu, te invocamus}

En el archivo del Real Colegio-Seminario de Corpus Christi de Valencia se encuentra un impreso francés con la partitura de un solo número independiente de lo que habría sido una colección (concretamente, se conserva el No. 4. "Choeur", con texto O Iesu, te invocamus ("Oh Jesús, te invocamos") [pp. 9-16]). Se ha grabado en formato apaisado (17,5 x $27 \mathrm{~cm}$.), y lleva la signatura $\mathrm{H}$ 8/7.

Dicha colección, o serie de partituras coleccionables, habría sido editada por entregas, tratándose la presente pieza de la "5e Livraison" (quinta entrega o fascículo). La obra, publicada en el año 1836 ("Journal 1836"), es posterior en sesenta y ocho años a la composición autógrafa, estando aquí concebida para Soprano, Contralto, Tenor, Bajo y órgano, y anotándose en la tonalidad de Do Mayor. La firma "Breitkopf \& Härtel" la había editado individualmente en 1812 en Leipzig, por lo que la fuente impresa conservada en Valencia es posterior en veinticuatro años a la primera edición individual de la pieza.

Se trata de un arreglo del Coro final (Nr. 8b) de la cantata Applausus (Hob.XXIVa:6), aquí impreso por el editor francés Nicou-Choron, como parece indicar su número de plancha, "N. C. 200", el cual nos llevaría a poder aventurar una datación aproximada para este impreso entre 1834 y $1836^{44}$.

La obra original puede consultarse en el tomo de la edición completa de las obras de Joseph Haydn, XXVII/2 [pp. 170-199], publicado por el Joseph Haydn-Institut de Colonia bajo la dirección de Georg Feder, editado por Heinrich Wiens junto con Irmgard Becker-Glauch e impreso en 1969 en la editorial G. Henle de Munich.

Anthony van Hoboken no da a conocer en su catálogo temático la fuente documental — partitura impresa - hallada en el archivo valenciano, como tampoco aparece en la obra editada por el Joseph Haydn-Institut de Colonia ${ }^{45}$.

44 La profesora Anik Devriès-Lesure, a quien agradezco mucho su valiosa información, ofrece expresamente una datación para este impreso, a partir de su número de plancha, la cual podría situarse entre junio de 1834 (fecha en que se habrían comenzado a utilizar estas iniciales) y 1842. No obstante, y dado que la mencionada profesora ofrece una datación del año 1836 para el número de plancha "N.C. 204", da la impresión de que, para la presente signatura ("N.C. 200"), deba aplicarse una datación anterior al citado año 1836.

45 El catálogo de Anthony van Hoboken (op. cit.) menciona copias en Austria (en nueve archivos y bibliotecas) y Alemania (dos). El Joseph Haydn-Institut menciona copias en Austria (en catorce archivos y bibliotecas), Alemania (cinco), Croacia (una) y República Checa (una). Para la copia española citada, véase: Climent, José: Fondos Musicales de la Región Valenciana, II. Real Colegio de Corpus Christi; Patriarca. Valencia, Instituto de Musicología, Institución Alfonso el Magnánimo, Diputación Provincial de Valencia, 1984, p. 405. 


\section{Salve Regina in g-Moll ("Salve Organo Solo") ${ }^{46}$}

Joseph Haydn compuso su Salve Regina en Sol menor (Hob.XXIIIb:2) en 1771. La obra está editada por H. C. Robbins Landon e impresa en 1964 en la editorial Ludwig Doblinger de Viena ${ }^{47}$.

En el archivo del Real Colegio-Seminario de Corpus Christi de Valencia se conserva, con signatura H 8/4, copia manuscrita de esta antífona mariana —-sólo las partichelas, con unas medidas de 22,3 x 31,7 $\mathrm{cm}$. - , anotada en la tonalidad original de Sol menor ${ }^{48}$. Cada partichela lleva una portada donde se puso el tipo de voz, el título de la obra y el nombre del autor. Así por ejemplo, la portada de la partichela del Tiple de $1^{\text {er }}$ Coro dice:

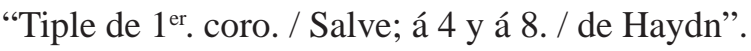

Existen, además, las siguientes partichelas: Alto de $1^{\text {er }}$ Coro, Tenor de $1^{\text {er }}$ Coro, Bajo de $1^{\text {er }}$ Coro, Tiple de $2^{\circ}$ Coro, Alto de $2^{\circ}$ Coro, Tenor de $2^{\circ}$ Coro (duplicado), Bajo de $2^{\circ}$ Coro (duplicado), Violón y Bajo, Órgano obligado.

Las partes vocales anotan nueve pautas por cada cara, mientras que la partichela para "Violón y Bajo" presenta diez, y la partichela para el órgano obligado traza cinco sistemas de líneas por cada cara. Estas partichelas manuscritas tampoco las menciona el catálogo temático de Hoboken ${ }^{49}$.

Según parece, Joseph Haydn sólo habría podido disponer para los servicios religiosos en el palacio de Eisenstadt de una exigua capilla, reducida en lo vocal a un mínimo de cuatro cantores, de modo que habría tenido que amoldarse a las circunstancias. Con el tiempo, un músico desconocido dividiría las partes vocales en solo y tutti ${ }^{50}$. El material custodiado en Valencia tampoco se ajusta a la instrumentación original, ya que en lugar de voces solistas, utiliza partes corales en dos Coros, faltando aquí, además, las partichelas de los dos violines y la viola ${ }^{51}$.

46 Esta Salve Regina no ha sido editada todavía por el Joseph Haydn-Institut de Colonia.

47 Vid. también: Webster, James: "Haydns Salve Regina in g-Moll (1771) und die Entwicklung zum durchkomponierten Zyklus”, en Haydn-Studien, vi/4 (1994), pp. 245-260.

48 En el Archivo de Música de las Catedrales de Zaragoza también se conservan dos juegos documentales sobre el texto de la "Salve Regina" de Joseph Haydn: E: Zac, D-215/1737 (en La Mayor) y E: Zac, D-215/1733 (en Sol menor; incompleta, sólo quedan las partes de las trompas y dos papeles de bajo). (Agradezco la información al Dr. Antonio Ezquerro).

49 Dicho catálogo (op. cit.) localiza copias en Austria (en nueve archivos y bibliotecas), Alemania (cinco), Bélgica (una), Eslovaquia (una), Hungría (una), e Italia (una). Para la copia española mencionada, véase: - Curment, José: Fondos Musicales de la Región Valenciana, II. Real Colegio de Corpus Christi; Patriarca. Valencia, Instituto de Musicología, Institución Alfonso el Magnánimo, Diputación Provincial de Valencia, 1984, p. 405.

50 Wyn Jones, David: Oxford Composer Companions: Haydn. Nueva York, Oxford University Press, 2002, p. 352.

51 Se encuentra, además, en dicho archivo del Real Colegio-Seminario de Corpus Christi, un catálogo editorial de música impreso, correspondiente a la colección La Lyre Sacrée ("Catalogue des Morceaux"), el cual se encuentra al comienzo de un libro encuadernado (véase la nota 4). Este catálogo incluye sello en caucho que imita la firma autógrafa de Colombier, con su dirección postal; se le ha estampado asimismo, a posteriori, el sello del "Real Colegio de Corpus Christi - Valencia". En los contenidos del listado numerado del citado catálogo, se hace referencia a la siguiente obra de Haydn, con el número 33 de catálogo y 6 francos como precio de venta: "Salve regina, à 4 voix sop, c.alto, ten, et basse avec orch, ou piano ou orgue". No se ha conservado en cambio la partitura impresa ahí mencionada. Por otro lado, comoquiera que Haydn compuso dos versiones de la antífona mariana, 
Si hubiera que aventurar una datación para esta fuente, podríamos decir que todas las copias manuscritas de las partichelas podrían haber sido realizadas por un mismo copista en la segunda mitad del siglo XIX, y acaso con una mayor concreción, entre1860 y 1890, aproximadamente.

\section{Hymne (Offertorium): "Ens aeternum, attende votis"}

Joseph Haydn compuso el ofertorio para coro y orquesta "Ens aeternum, attende votis" ("Ser eterno, atiende a los votos") (Hob.XXIIIa:3) en Sol Mayor, antes de 1772, fecha de la que data la fuente más antigua que conocemos ${ }^{53}$, conservada, bajo la signatura $100 \mathrm{Gbb} / \mathrm{H} 4$, en el Instituto Musicológico del Convento de los Hermanos de la Misericordia ("Musikwissenschaftliches Institut, aus dem Konvent der Barmherzigen Brüder"), en la localidad austríaca de Graz.

Esta fuente documental se encuentra descrita en el tomo de la edición completa de sus obras, XXVII/1, Kantaten mit Orchester für das Fürstenhaus Esterházy ("Cantatas con orquesta para la casa principesca de Esterházy”) [pp. 172 y 182], editado por Andreas Friesenhagen y Sonja Gerlach e impreso en el año 2000 en la editorial G. Henle de Munich.

Ens aeternum, forma parte de un pasticcio, el cual incluye también un contrafactum ${ }^{54}$ de una parte de la cantata en Sol Mayor para Esterházy, razón por la cual se describe esta fuente (aunque falta su parte central) en el tomo de la edición completa de las obras de Joseph Haydn, XXVII/1.

En la versión que se custodia en el archivo del Real Colegio-Seminario de Corpus Christi de Valencia - un impreso francés con la partitura en formato apaisado $(17,5$ x $27 \mathrm{~cm}$.) y signatura $\mathrm{H}$ 8/5-, aparece esta pieza como un número independiente dentro de lo que habría sido una colección (concretamente, se conserva el No. 3 "CHOEUR A 4 VOIX", con texto Ens aeternum, attende votis). Se anota para Soprano, Contralto, Tenor, Bajo, y órgano, en la tonalidad de Sol Mayor. Dicho impreso se extiende entre las que habrían sido las páginas 12 a 20 de la colección, editado por Nicou-Choron a juzgar por su número de plancha, "N. C. 204" (datable por tanto entre junio de 1834 y 1842, y más concretamente, con toda probabilidad, en el año 1836$)^{55}$.

una en Mi Mayor, y otra en Sol menor, y que el catálogo impreso no especifica la tonalidad correspondiente, resulta imposible por tanto, únicamente a partir de tales datos, saber si se podría tratar de la obra de nuestro interés, o de la otra.

52 El ofertorio "Ens aeternum, attende votis" no ha sido editado todavía por el Joseph Haydn-Institut de Colonia. Ofrezco la información aportada por el tomo de la edición completa XXVII / 1 Kantaten mit Orchester für das Fürstenhaus Esterházy ("Cantatas con orquesta para la casa principesca de Esterházy"). 2004.

53 Según me consta por carta recibida del Joseph Haydn-Institut de Colonia (Dr. Robert von Zahn), de 25 de junio de

54 Contrafactum: modificación de un texto cantado (a menudo de uno profano a uno religioso, o viceversa) manteniéndose la melodía. En su sentido más amplio, un contrafactum es una obra vocal en la que un texto nuevo sustituye al original. (WYN JoNES, David: Oxford Composer Companions: Haydn. Nueva York, Oxford University Press, 2002, pp. 51-52).

55 Agradezco esta información a la profesora Anik Devriès-Lesure, en su carta del 11 de febrero de 2005. 


\section{Missa brevis Sancti Ioannis de Deo "Kleine Orgelmesse" $" 56$}

Joseph Haydn compuso su Missa brevis Sancti Ioannis de Deo "Kleine Orgelmesse" (Misa breve a San Juan de Dios, "Pequeña Misa para órgano") (Hob. XXII:7) alrededor de 1775, en la tonalidad de Si bemol Mayor y con una instrumentación fundamentada en las cuatro voces mixtas de Coro con Soprano Solo (en Benedictus), violín 1 y 2, violonchelo y contrabajo, y órgano. La obra puede consultarse en el tomo de la edición completa de sus obras, XXIII/2 [pp. 1-19], publicado por el Joseph Haydn-Institut de Colonia bajo la dirección de Jens Peter Larsen, editado por H. C. Robbins Landon junto con Karl Heinz Füssl y Christa Landon e impreso en 1958 en la editorial G. Henle de Munich. (Todavía no ha aparecido su análisis o informe crítico).

En el archivo de la Catedral de Valencia, y bajo signatura 153/7, se encuentra una partitura impresa con esta misma composición (editada por William Galloway, para Soprano, Contralto, Tenor, Bajo, y órgano), así como una partitura manuscrita (asimismo para voces y órgano), y las correspondientes partichelas manuscritas. El citado impreso conservado en Valencia lleva por título:

"HAYDN'S MASSES, / with / an Accompaniment for the / ORGAN, / Arranged from the Full Score / and respectfully inscribed by permission to / his serene Highness / The Prince Esterházy / By / VINCENT NOVELLO. / Organist to the Portuguese Embassy in London. / Ent. ${ }^{\mathrm{d}}$ at Sta. ${ }^{\mathrm{s}}$ Hall - Price... / London, Published by W. Galloway, at his Music \& Musical Instrument Warehouse. / $N^{o}$. 21, Wigmore Street, Cavendish Square. / Where may be had lately published. / [Y en tamaño de letra menor:] V. Novello's Collection of Sacred Music in two Vols. price 1,6 each Vol. / Collection of Mottets for the Offertory in 6 Books 10,6 ea. Book. / V. Novello's 72 Easy Masses calculated for Small Choirs in 3 Vols. 1,30 ea. Vol. / Edition of Mozart's Masses in 15 Nos"57.

El título propio del encabezamiento de la página 2 de dicha partitura impresa, lee:

56 En opinión de Armin Raab, en los países de habla alemana —Alemania, Austria y Suiza — se utiliza, con frecuencia, el sobrenombre "Kleine Orgelmesse" (Pequeña Misa para órgano), si bien también es correcto decir, sin que ello tenga mayor importancia, "Kleine Orgelsolomesse" (Pequeña Misa para solo de órgano"). Por su parte, David Wyn Jones nos dice que en el sobrenombre "Kleine Orgelmesse" (Pequeña Misa para órgano), el término "Misa para órgano" se refiere, estrictamente hablando, a una obra acompañada únicamente de un órgano, una forma errónea con la que a veces se hace referencia a la obra, mientras que el sobrenombre "Kleine Orgelsolomesse" (Pequeña Misa para solo de órgano) refleja el amplio uso en solitario del órgano en el Benedictus, y la diferencia de la "Grosse Orgelsolomesse" (Gran Misa para sólo de órgano). (Wyn JonEs, David: Oxford Composer Companions: Haydn. Nueva York, Oxford University Press [2002], p. 197).

57 "MISAS DE HAYDN, / con / un Acompañamiento para / ÓRGANO, / Arregladas a partir de la Partitura Completa / y respetuosamente inscritos con permiso de / su serena Alteza / El Príncipe Esterházy / Por / VINCENT NOVELLO. / Organista de la Embajada Portuguesa en Londres. / Entrado en Sta.s Hall - Precio... / Londres, Publicado por W. Galloway, en su Almacén de Música e Instrumentos Musicales. / No . 21. Calle Wigmore, Plaza Cavendish. / Donde quizá sea publicado con posterioridad. / Colección de V. Novello de Música Sagrada en dos volúmenes, precio 1,6 cada volumen. Colección de Motetes para el Ofertorio en 6 libros, 10,6 cada libro. 72 Misas Fáciles de V. Novello pensadas para Coros Pequeños en 3 volúmenes, 1,30 cada volumen. / Edición de las Misas de Mozart en 15 Números". 
"HAYDN's MASS in BJ, N. 8. / (Missa Brevis, or Short Mass for the Minor Festivals) / The Organ Part by V: NOVELLO. / From a Manuscript Score / in Haydn's own handwriting; / In the poss. ${ }^{\mathrm{n}}$ of The Rev. ${ }^{\mathrm{d}}$ C. J. Latrobe. ${ }^{, 58}$.

La copia manuscrita de la partitura se podría datar hacia el segundo tercio del siglo XIX. Y el juego de partichelas — copias de diferentes copistas — entre 1825 y 1880, aproximadamente.

Anthony van Hoboken nos aporta información en su catálogo temático a propósito del impreso de esta Missa brevis de Joseph Haydn ${ }^{59}$. Se trata, según él, de una transcripción para voces y órgano de la Missa brevis Sancti Ioannis de Deo "Kleine Orgelmesse", realizada en torno a 1820 por Vincent Novello (*1781; †1861), quien la editó en primer lugar. Luego, se encargó de su publicación el editor William Galloway, y finalmente, después de 1828, publicó nuevamente la transcripción el hijo de Novello, Joseph Alfred (*1810; †1896). Incluso, después de 1847, iba a aparecer publicada una edición más barata.

Las copias manuscritas de las partichelas halladas en el archivo de la Catedral de Valencia que presentan unas medidas de 22,5 $(28,5)$ x 31,0 $(20,0) \mathrm{cm}$. - , son: Tiple $1^{\circ}$ de $1^{\circ}$. Coro, Alto de $1^{\circ}$. Coro, Tenor de $1^{\circ}$. Coro, Bajo de $1^{\circ}$. Coro; Tiple $2^{\circ}$ de $2^{\circ}$. Coro, Alto de $2^{\circ}$. Coro (duplicado; el segundo ejemplar, en copia posterior, de 1877), Tenor de $2^{\circ}$. Coro, Bajo de $2^{\circ}$. Coro (cuadruplicado; dos ejemplares del juego original, y otros dos en copia de fecha posterior); "para regir Contrabajo y Violoncello" (duplicado; uno de los ejemplares, con notas añadidas en tamaño menor, indicando las entradas de otros instrumentos o voces); "Acompañam ${ }^{\text {to }}$. Obligado al Organo" (realizado y/o cifrado). Estos efectivos no se ajustan con la instrumentación original: se añade un segundo Coro y faltan las partichelas de los violines 1 y 2. En la primera página de las partichelas de cada una de las voces se imprimió un sello que dice:

“Archivo metropolitano Valencia -2357”.

Estas partichelas manuscritas no se hallan referenciadas en el catálogo temático de Hoboken $^{60}$.

58 "MISA DE HAYDN en Si bemol, No 8. / (Missa Brevis, o Misa Breve para los Festivales menores) / La parte de órgano por V: NOVELLO. / A partir de la partitura manuscrita autógrafa de Haydn; / En posesión del reverendo C. J. Latrobe".

59 Новокеn, Anthony van: Thematisch-bibliographisches Werkverzeichnis, Band III: Register- Addenda und Corrigenda. Mainz: B. Schott's Söhne, 1978, p. 59.

60 Hовокеn, Anthony van: Thematisch-bibliographisches Werkverzeichnis. (Volumen II: "Vokalwerke"). Maguncia, Hijos de B. Schott, 1971, pp. 84-85. Se mencionan ahí copias en Austria (en dieciocho archivos y bibliotecas), Alemania (nueve), República Checa (cinco), Eslovaquia (una), Hungría (una), e Italia (una). Para la copia española citada, véase: CLIMENT, José: Fondos Musicales de la Región Valenciana, I. Catedral Metropolitana de Valencia. Valencia, Institución Alfonso el Magnánimo, Diputación Provincial de Valencia, 1979, p. 205. 
En los dos movimientos más largos del Ordinario, el Gloria y el Credo, a medida que se van incorporando las voces, cantan simultáneamente textos diferentes ${ }^{61}$. Este evidente defecto en la aplicación de los textos (pues no deben repetirse las palabras, sino cantarse todo de manera correlativa, sin entorpecerse lo que dicen unas voces y otras, y sin resultados finales auditivos que difieran de lo estrictamente legislado desde Roma), es, para el caso valenciano, sabiamente detectado - seguramente gracias a su formación como músico y sacerdote— por José Climent ${ }^{62}$, a pesar de que, como he tenido oportunidad de comprobar, ya el propio Joseph Haydn lo compuso así.

Este tipo de prácticas, no infrecuentes fuera de nuestras fronteras, aunque francamente extrañas dentro del ámbito hispánico (acaso por un mayor celo de nuestros compositores en el tratamiento de los textos litúrgicos se ha atribuido tradicionalmente a un hipotético carácter de estas grandes obras de la literatura religiosa universal con coro y orquesta (Misas de Haydn, Mozart y Beethoven), más como piezas concebidas fundamentalmente a manera de "obras de concierto", que no, propiamente, como piezas para ser interpretadas en el ámbito y contexto de la liturgia y el templo.

Por tanto, la edición de Novello coincide en este sentido con el original de Haydn. Así sucede también, obviamente, con el ejemplar de la partitura impresa que se conserva en Valencia. Pero en el caso de las copias manuscritas se optó, en cambio, seguramente para cumplir más cabalmente con las exigencias litúrgicas en lo relativo a los textos, por la aplicación de un mismo y único texto. Es decir, por la corrección del original. Esta copia manuscrita presenta la partitura para voces y órgano (cuya portada reza "Missa á 4 y á 8 Obligada al / Organo / del M ${ }^{\text {tro }}$. Haydn”).

\section{Missa Cellensis Fatta per il Signor Liebe de Kreutzner "Mariazellermesse", Misa de Mariazell}

Joseph Haydn compuso en 1782 la Missa Cellensis (Hob.XXII:8) en Do Mayor. La obra puede consultarse en el tomo de la edición completa de sus obras, XXIII/2 [pp. 20-88], publicado por el Joseph Haydn-Institut de Colonia bajo la dirección de Jens Peter Larsen, editado por H. C. Robbins Landon junto con Karl Heinz Füssl y Christa Landon e impreso en 1958 en la editorial G. Henle de Munich. (Todavía no se ha publicado su estudio analítico o informe crítico correspondiente).

61 La Missa brevis St Ioannis de Deo "Kleine Orgelsolomesse" sigue el sistema de poner los dos movimientos más largos del Ordinario politextualmente, es decir, varias frases se cantan simultáneamente para acabar el texto en una cuarta parte del tiempo aproximadamente. (Wyn Jones, David: Oxford Composer Companions: Haydn. Nueva York, Oxford University Press, 2002, p. 237). Véase el tomo de la edición completa de las obras de Joseph Haydn XxIII/2 [pp. 1-19]: en concreto, el Gloria comprende las páginas 3 y 4, y el Credo, las páginas 5-9 de la edición alemana.

62 Climent, José: Fondos Musicales de la Región Valenciana, I. Catedral Metropolitana de Valencia. Valencia, Institución Alfonso el Magnánimo Diputación Provincial de Valencia, 1979, p. 205. 
En el archivo de la Catedral de Valencia se conserva una copia manuscrita de esta partitura (encuadernada en cartón, de 21,2 x 31,2 cm.), así como copias manuscritas de las partichelas —con medidas de $22(20,5)$ x $31(29,0) \mathrm{cm}$., aproximadamente-, con la signatura 153/8.

En la portada de la partichela del violín $1^{\circ}$ dice:

"Para Regir / Violino Primo / Missa / de / Haydn.".

Conviene mencionar que, en la documentación de Valencia ${ }^{63}$, las trompas hacen la parte de las dos trompetas originales (tal vez, porque no se dispusiera de trompetas en la catedral, o porque no las hubiera en ese preciso momento); faltan también el timbal y el órgano. Pero, en contraposición, se añaden copias manuscritas para el Bajo de segundo Coro, "baso", una parte compartida para el "Basso e Violoncello" y las mencionadas dos trompas.

Aparte de la partitura, las partes individuales tanto vocales como instrumentales conservadas en la Catedral de Valencia son las siguientes: "Tiple $1^{\circ}$ Coro", "Alto $1^{\circ}$ Coro", "Tenor $1^{\circ}$ Coro", "Bajo $1^{\circ}$ Coro", "Tiple $2^{\circ}$ Coro", "Alto $2^{\circ}$ Coro", "Tenor $2^{\circ}$ Coro", "Bajo $2^{\text {do }}$. Coro" (triplicado); "Violino Primo" (triplicado; con un primer ejemplar, "Para Regir", y otro que anota precisamente ser "duplicado"), "Violin 2"" (duplicado), "Viola", "Basso e Violoncello" (—que sirve para el contrabajo-; triplicado;

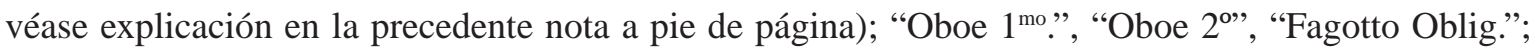
"Corno Primo In Cut", "Corno Segundo In Cut".

Sin indicación expresa de fecha, la copia manuscrita de esta partitura podría datarse entre 1860 y 1890, aproximadamente. En cuanto a la copia manuscrita de las partichelas, se trata de un juego de voces de una misma mano (excepto dos ejemplares de Bajo de $2^{\text {do }}$ Coro, que son más tardíos). Las copias más antiguas son las destinadas a "Violone e Violonzello", y "Corno primo", respectivamente (ambas de igual mano, aunque distinta a la anterior mayoritaria; probablemente sean copia manuscrita a partir de algún impreso extranjero - a juzgar por sus anotaciones en italiano, y su no muy frecuente en copias instrumentales manuscritas de la época en ámbito hispánico, formato vertical—). Por lo demás, existen todavía otras diversas manos que copian el resto de partichelas manuscritas. La datación de estos materiales podría situarse, aproximadamente, desde principios del siglo XIX hasta mediados de la centuria (con algunos añadidos posteriores aislados, como en el caso de la partichela para Bajo de $2^{\mathrm{do}}$ Coro).

63 Existe un cuadernillo para "Baso e Violoncello" (en cuyo encabezamiento se anota curiosamente, "Biolone"), el cual está duplicado (el segundo ejemplar, para "Basso e Violoncello", anota en su encabezamiento "Violone e Violonzello"); este segundo ejemplar parece ser el principal de los dos, dado que anota en su portada, bien el precio, bien un número de antiguo inventario "15P", además del contenido de lo que habría sido un juego completo de partichelas: "19 Papeles"; por lo demás, la copia del segundo ejemplar, en formato vertical, frente a la del primero, en formato apaisado, denota, por algunas características caligráficas, que la copia pudo haber sido sacada a partir de algún ejemplar impreso preexistente que no se nos haya conservado (?): en este sentido, llama la atención que la copia anota las expresiones italianas "Volti Subito", "Bassi", o "Fine", en lugar de las más habituales en España "V.P." (por "Volti Presto"), "Bajos", o "Fin", así como algunas tachaduras y un modo muy peculiar, caligráficamente hablando, de anotar algunos matices expresivos. Por otra parte, además de los dos ejemplares mencionados, se conserva un tercero para "Acomp ${ }^{\text {to }}$. $\mathrm{p}^{\mathrm{a}}$. el Contrabajo / y Violón / Misa Con Ynstrumental de Orq ${ }^{\text {ta }}$. / Por el Sor. Haydn.”, el cual anota en su encabezamiento ser para "Violone é Violonzello". 
He podido encontrar en el Archivo de Música del Real Colegio-Seminario de Corpus Christi de Valencia, en un sobre, y sin catalogar hasta la fecha, un nuevo juego documental con una copia de esta misma composición musical. Los materiales hallados — partichelas de la Missa Cellensis (Hob. XXII:8)_, se encontraban traspapelados entre otras partichelas pertenecientes a la Missa in Es In honorem Beatissimae Virginis Mariae "Grosse Orgelsolomesse" (Hob.XXII:4). El hallazgo de esta "nueva" copia de la Missa Cellensis Fatta per il Signor Liebe de Kreutzner "Mariazellermesse", no aparece por tanto reflejado en el catálogo disponible de este archivo, a cargo de José Climent ${ }^{64}$.

Los materiales encontrados aparecieron envueltos con un folio de gran tamaño de papel pautado doblado a modo de solapa (con nueve pautas, en cuyo margen superior derecho figura el número 34), para, dentro de dicha solapa, agrupar las diferentes partichelas de una Misa no explicitada de Haydn, la cual he podido identificar como la Missa Callensis compuesta para el señor Liebe de Kreutzuer "Misa de Mariazell" (Hob.XXII:8).

Estas partichelas se copian en formato apaisado (21,5 x 31,5 cm.), anotando en cada una de sus portadas el tipo de voz o instrumento, la forma musical de la composición y el nombre del autor. Por ejemplo, en la portada de la partichela del Tiple de Coro $1^{\circ}$ dice:

“Tiple $\underline{1^{\circ}}$. Coro, / Misa de Haydn,”.

Existen, además, las siguientes partichelas: Alto $1^{\circ}$ Coro, Tenor $1^{\circ}$ Coro, Bajo $1^{\circ}$ Coro, Tiple $2^{\circ}$ Coro, Alto $2^{\circ}$ Coro, Tenor $2^{\circ}$ Coro, Bajo $2^{\circ}$ Coro, Violín $1^{\circ}$, Viola, Contrabajo. Por consiguiente, y considerando para ello la instrumentación original, faltan las partichelas de violín $2^{\circ}$, violonchelo, dos oboes, fagot, dos trompetas, timbal y órgano.

Las partes vocales anotan ocho pautas por cada cara, mientras que las partes para el violín $1^{\circ}$, viola, y contrabajo, presentan diez pentagramas por cada cara.

La partichela de violín $1^{\circ}$ se ve de otra mano, y tanto ésta como la partichela de la viola, seguramente han sido sacadas de algún impreso, a juzgar por las abreviaturas utilizadas en la escritura musical, así como por algunas indicaciones en italiano. En la partichela de contrabajo hay una nota al pie que hace referencia al comienzo del Benedictus que dice: "Cuando se acompaña al Organo, se toca el Benedictus punto alto".

Sin indicación expresa de fecha alguna, la datación de esta fuente podría fijarse hacia el segundo tercio del siglo XIX, aproximadamente.

Obviamente, el catálogo temático de Anthony van Hoboken no menciona este legajo, como tampoco otras copias manuscritas de esta misma composición que se han conservado en España y que he podido

64 Climent, José: Fondos Musicales de la Región Valenciana, II. Real Colegio de Corpus Christi; Patriarca. Valencia, Instituto de Musicología, Institución Alfonso el Magnánimo, Diputación Provincial de Valencia, 1984. 
localizar, ubicadas en el archivo de la Catedral de Granada ${ }^{65}$. El hecho de que se hayan localizado dos copias de esta obra en una misma ciudad, Valencia, así como el elevado número de composiciones litúrgicas de este autor conservadas en la actual comunidad autónoma, es muestra definitiva del gran y temprano éxito de la música del compositor vienés no sólo dentro del ámbito eclesiástico español, sino, muy especialmente, del papel puntero que en este sentido pudo haber desempeñado Valencia respecto a otras localidades del área hispánica ${ }^{66}$.

\section{Die Sieben Worte (Vokalfassung).}

Como es bien conocido, esta célebre composición de Joseph Haydn surgió por encargo —en torno a 1785- del sacerdote José Sáenz de Santa María, marqués de Valde-Íñigo (*Veracruz México-, 25.04.1738, †Cádiz, 26.09.1804), cuya idea era poner música intercalada entre las Siete últimas Palabras pronunciadas por Cristo en la $\mathrm{Cruz}^{67}$, las siete oraciones sagradas del Sermón de las Tres Horas, y además, la descripción musical de un terremoto. Para ello, el citado marqués solicitó a su amigo Francisco de Paula María de Micón, segundo marqués de Méritos (*Cádiz, 15.11.1735; $†$ Madrid, 09.06.1811), promover el encargo (mediante las cartas correspondientes) a Joseph Haydn, con vistas a realizar públicamente una primera actuación en el Oratorio de la Santa Cueva de Cádiz con dicha música, en la Semana Santa de 1786 o en la de 1787.

El título de la composición era: "Musica Instrumentale Sopra le sette ultime Parole del nostro Redentore in Croce o sieno Sette Sonate con un Introduzione ed al Fine un Terremoto" (Música instrumental sobre las Siete últimas Palabras de Nuestro Salvador en la Cruz, o siete sonatas con una introducción y al final un terremoto). Joseph Haydn dijo que

65 El catálogo temático de Hoboken (op. cit.) menciona copias en Austria (en quince archivos y bibliotecas), Alemania (seis), República Checa (cuatro), Italia (dos), Eslovaquia (una) y Hungría (una). Para la copias españolas citadas, véase: Cument, José: Fondos Musicales de la Región Valenciana, I. Catedral Metropolitana de Valencia. Valencia, Instituto de Musicología, Institución Alfonso el Magnánimo, Diputación Provincial de Valencia, 1979, p.205. López CALo, José: Catálogo del Archivo de Música de la Catedral de Granada. Tomo II. Granada, Centro de Documentación Musical de Andalucía, 1991, pp. $536-537$.

66 Esta obra (la "Misa de Mariazell"), coincide con una fuente conservada en el Archivo de Música de las Catedrales de Zaragoza, identificada como "Misa en Do Mayor", cuya copia se data en "Zaragoza 24 de Abril / [18]69" (se trata de una copia muy voluminosa, con partitura y partichelas, hoy conservada en cuatro carpetas, y con la signatura E: Zac, D-228/1936). La instrumentación ahí presente es la siguiente: S, A, T, B; vl 1, 2, vla, cb; ob 1, cl 1, 2, fag; cor (in F) 1, 2; figle. La partitura anota también en su parte inferior una parte para el órgano (acaso para rellenarla con la reducción de toda la obra), aunque no se ha copiado su contenido. Por tanto, respecto a la instrumentación original, la copia zaragozana carece del violonchelo, oboe segundo, dos trompetas, timbales y órgano, aunque añade dos clarinetes, dos trompas y figle. [Agradezco la información al Dr. Antonio Ezquerro y al Dr. Luis Antonio González Marín].

67 Sobre la tradición musical y contexto de Las Siete Palabras, debe consultarse: González Valle, José Vicente: [Francisco Javier García Fajer "el Españoleto":] Siete Palabras de Cristo en la Cruz. Barcelona, Consejo Superior de Investigaciones Científicas, Institución “Milà i Fontanals”, Departamento de Musicología, 2000. Y más recientemente: EzQUERRo EsTEBAN, Antonio: Música instrumental en las catedrales españolas de la época ilustrada (conciertos, versos y sonatas, para chirimía, oboe, flauta y bajón -con violines y/u órgano-, de La Seo y El Pilar de Zaragoza). Barcelona, Consejo Superior de Investigaciones Científicas, Institución "Milà i Fontanals", Departamento de Musicología, 2004. 
“...más se debía la composición que remitía a la exposición que había recibido por escrito del señor De Micón, que a su propia invención, porque aclaraba de un modo tan singular todos los pasos, que le parecía, cuando estaba leyendo las instrucciones recibidas de España, leer sólo música" ${ }^{68}$.

Para la composición de Las Siete últimas Palabras de Cristo en la Cruz, el músico vienés utilizó una compilación de dichas palabras, extraídas de los cuatro Evangelios, mientras que para el texto de El Terremoto, se inspiró en el texto de la cantata Der Tod Iesu (“La muerte de Jesús”), escrita en 1756 por Karl Wilhelm Ramler $(* 1725 ; \nmid 1798)$.

La composición de Joseph Haydn, encargada desde España, conoció varias versiones, a saber:

1) (Hob.XX/1), la versión original para orquesta (compuesta en 1786);

2) (Hob.XX/1), para cuarteto de cuerda (Hob.III:50-56), un arreglo de la versión orquestal que Joseph Haydn preparó, publicado por Artaria en 1787;

3) (Hob.XX/1), para teclado, un arreglo de un músico desconocido, que Joseph Haydn autorizó, publicado también por Artaria en 1787; y

4) (Hob.XX/2), para voces solistas, coro y orquesta (compuesta en 1795-1796) ${ }^{69}$, con texto del maestro de capilla de Passau, Joseph Friebert, corregido por Joseph Haydn en colaboración con el barón Gottfried van Swieten.

En España, esta composición gozó de buen predicamento, como así lo atestiguan las copias conservadas en diferentes archivos, casi en exclusiva — por su carácter "funcional" - en su versión dotada de texto. Las Siete Palabras continuaron ejecutándose el día de Viernes Santo en la "obscura y honda capilla de la calle del Rosario" de Cádiz, dejando, por ejemplo y de manera destacada, huella posterior en el espíritu de Manuel de Falla, compositor gaditano nacido en 1876, que a los nueve años de edad, junto con su madre, ya interpretaba esta composición en la Iglesia de San Francisco ${ }^{70}$ de Cádiz.

En todo caso, la obra que aquí analizamos se encuentra en el tomo de la edición completa de las obras de Joseph Haydn, XXVIII/2 [pp. 1-184], publicado por el Joseph Haydn-Institut de Colonia bajo la dirección de Jens Peter Larsen, editado por Hubert Unverricht e impreso en 1961 en la editorial G. Henle de Munich. (Todavía no se ha publicado su estudio crítico).

68 Stevenson, Robert: "Haydn’s Iberian World Connections", en: Inter-American Music Review, 4 (1982), pp. 8-12.

69 Wyn Jones, David: Oxford Composer Companions: Haydn. Nueva York, Oxford University Press, 2002, p. 359.

70 Pahissa, Jaime: Vida y obra de Manuel de Falla .Buenos Aires, Ricordi Americana, 1956, pp. 22 y 23. 


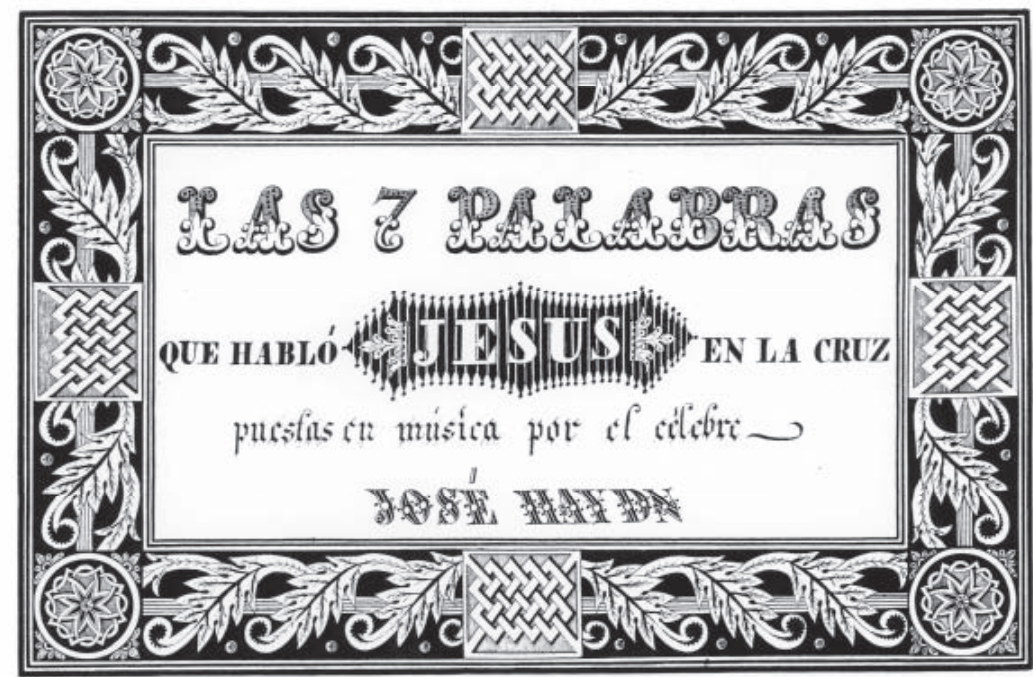

Figura 4: Las Siete Palabras de Cristo en la Cruz [1795-1796] de F. J. Haydn (Hob.XX/2). Portada de la partitura manuscrita, E-VAc, signatura 154/3.

Por su parte, en el archivo de la Catedral de Valencia existe copia manuscrita de la partitura, así como de la partichela de "contrabajo y violonchelo" "11, todo ello bajo la signatura 154/3.

En la portada de la partitura (de 21,5 x 31,0 cm., encuadernada con tapas de cartón y con lomo en piel marrón, que lee: "LAS / SIETE / PALABRAS") y que semeja el aspecto de un grabado, dice:

"LAS 7 PALABRAS / QUE HABLÓ JESÚS EN LA CRUZ / puestas en música por el célebre / JOSÉ HAYDN".

Sin indicación expresa de fecha alguna, la datación de esta fuente podría fijarse, de forma aproximativa, hacia el tercer cuarto del siglo XIX, y acaso con una mayor concreción, entre 1860 y 1890 .

Entretanto, cotejando íncipits, he podido identificar en el Archivo de Música del Real ColegioSeminario de Corpus Christi de Valencia otra copia manuscrita de esta misma composición, aunque ahí figura como anónima (carpeta núm. 7-A/16), con la partitura para dos Coros (excepto en El Terremoto) e instrumento de teclado - el $2^{\circ}$ Coro se comienza a escribir en la $1^{\text {a }}$ Palabra solamente- De hecho, el catálogo de José Climent ofrece la música de esta obra, en el apartado de "Anónimos"72.

71 Esta partichela, de 21,1 x 30,5 cm., se ha encuadernado en el mismo volumen, junto a la partitura.

72 Climent, José: Fondos Musicales de la Región Valenciana II, Real Colegio de Corpus Christi, Patriarca. Valencia, Instituto de Musicología, Institución Alfonso el Magnánimo, Diputación Provincial de Valencia, 1984, p. 132. 
El manuscrito — que mide 22’3 x $31 \mathrm{~cm}$ - fue encuadernado con tapas de cartón, y lomo de color verde. En el interior de la cubierta se ha anotado con bolígrafo azul: "Ex libris / Vicente Ripollés"73. La paginación no se ha llevado a cabo con exactitud, y además, faltan los compases 116 a 123, es decir, los últimos ocho compases de la obra. Tampoco aparecen en esta copia algunas indicaciones originales de tempo, a saber: $5^{\text {a }}$ Palabra "Adagio" y en El Terremoto se señala el tempo, pero falta la indicación del carácter de la música, es decir, e con tutta la forza.

Existe, pues, en el archivo del Real Colegio-Seminario de Corpus Christi (Patriarca) de Valencia, copia manuscrita de la partitura de Las Siete Palabras (con signatura, según José Climent, AN 7/16, y según el actual organista, Vicente Ferrer, carpeta núm. 7-A/16), la cual tiene en común con el ejemplar de la Catedral de Valencia el texto, que no es el latino de los Evangelios, sino que son versos en castellano.

Por cierto, en ambas fuentes, la música del canto coral a capella que precede a la $6^{\mathrm{a}}$ Palabra, es la misma para los dos casos valencianos (de escritura contrapuntística), aunque no es la misma que figura en el tomo de la edición completa de las obras de Joseph Haydn (de escritura homófona). Además, en las dos fuentes valencianas falta también la segunda Introducción en La menor, -sólo para instrumentos de viento- y que precede a la $5^{\mathrm{a}}$ Palabra. Después de la $7^{\mathrm{a}}$ Palabra sigue un Credo (nicenoconstantinopolitano), incompleto, con texto latino:

\section{CREDO}

Credo in unum Deum

Patrem omnipotentem, factorem caeli et terrae, visibilium omnium et invisibilium.

Et in unum Dominum Iesum Christum,

Filium Dei unigenitum,

et ex Patre natum ante omnia saecula.

Deum de Deo, lumen de lumine, Deum verum de Deo vero, genitum, non factum, consubstantialem Patri:

per quem omnia facta sunt.

Qui propter nos homines et propter nostram salutem descendit de caelis.

Et incarnatus est de Spiritu Sancto

ex Maria Virgine, et homo factus est.

73 Recuérdese que Vicente Ripollés Pérez $(* 1867$; $\uparrow 1943)$ fue maestro de capilla del Real Colegio-Seminario de Corpus Christi de Valencia entre el 6 de julio de 1895 y el 28 de agosto de 1902. 
Crucifixus etiam pro nobis sub Pontio Pilato;

passus et mortuus est ${ }^{74}$,

$[\ldots]$

[Y tras él, El Terremoto, con texto nuevamente en castellano].

La copia manuscrita de la partitura podría datarse entre 1825 y 1875, aproximadamente.

En cuanto a los textos utilizados en España para la composición de Las Siete Palabras, parece ser que éstos comenzaron a musicalizarse a comienzos del siglo XVI; y según parece, con la llegada del Concilio de Trento a mediados de aquel siglo, se produjo una depuración de textos litúrgicos, que pudo dar como resultado el que dejaran de cantarse Las Siete Palabras de Cristo en la Cruz dentro del canto de la Pasión del Viernes Santo. Paralelamente, el pueblo cristiano había iniciado una tradición popular, fuera de la liturgia, con textos en lengua vernácula ${ }^{75}$.

Recientemente he tenido la satisfacción de encontrar, en los fondos de la Biblioteca Valenciana, ubicada en el Monasterio de San Miguel de los Reyes, dos ejemplares impresos (1 y 2 ) con el texto de Las Siete Palabras. Ambos constan de dieciséis páginas sin numerar.

De los dos impresos, el primero de ellos (1) —en formato francés o vertical, de 14,5 x 10,3 cm., signatura XVIII/1706(32)—, fue encuadernado (y da la impresión de haber sido guillotinado para su encuadernación) incorporándose a un grueso volumen misceláneo (con tapas de cartón de color marrón), de 21,7 x 15,5 cm. El volumen en su conjunto, reúne, además del impreso de nuestro interés, otras obras de temática variada, y en su lomo dice "VARIOS / DE / VALENCIA", todo bajo la signatura (XVIII/1706). En el reverso de la cubierta del volumen se lee: "BIBLIOTECA / DE / F. CARRERES". Así, pues, este impreso perteneció a Francisco Carreres Vallo $(* 1858 ; \dagger 1936)^{76}$. En el

74 Creo en un solo Dios, / Padre todopoderoso, Creador del cielo y de la tierra, / de todo lo visible y lo invisible. / Creo en un solo Señor, Jesucristo, / Hijo único de Dios, / nacido del Padre antes de todos los siglos: / Dios de Dios, Luz de Luz, Dios verdadero de Dios verdadero, / engendrado, no creado, de la misma naturaleza del Padre, / por quien todo fue hecho; / que por nosotros los hombres y por nuestra salvación / bajó del cielo, / y por obra del Espíritu Santo / se encarnó de María, la Virgen, y se hizo hombre; / y por nuestra causa fue crucificado en tiempos de Poncio Pilato; / padeció y murió, / [...] [La musicalización de este texto en ambas fuentes valencianas, termina ahí].

75 Sobre la tradición del canto de Las Siete Palabras, vid.: González Valle, José Vicente: [Francisco Javier García Fajer "el Españoleto":] Siete Palabras de Cristo en la Cruz, op. cit., 2000. EzQuerro Esteban, Antonio: Música instrumental en las catedrales españolas de la época ilustrada (conciertos, versos y sonatas..., op. cit., 2004.

76 Francisco Carreres Vallo $(* 1858 ; \uparrow 1936)$, fue Presidente de Acción Bibliográfica Valenciana hasta 1936. Dedicó su vida a la creación de una importante biblioteca de temática valenciana, en especial de documentación relativa a las fiestas y solemnidades religiosas celebradas en la Ciudad y el Reino de Valencia. Su hijo, Salvador Carreres Zacarés (*1882; †1963), fue Director del Archivo del Ayuntamiento de Valencia, y gracias a las fuentes procedentes de dicho archivo y al material acumulado en la biblioteca de su padre, publicó Ensayo de una bibliografía de Libros de Fiesta celebradas en Valencia y su antiguo Reino (1925), entre otras obras. El hijo de éste, Francisco Carreres de Calatayud $(* 1916 ; \uparrow 1987)$, fue profesor de inglés en el Instituto de Bachillerato Luis Vives y en la Universidad de Valencia, así como Director del "British Institute" de Valencia. De su producción son los estudios literarios plasmados en los libros Las fiestas valencianas y su expresión poética (1949). Recuperó y prologó Rimas humanas y divinas de Gaspar Aguilar (1951) y fue miembro del "Queen's Collage" de Oxford. Francisco Carreres Vallo, Salvador Carreres Zacarés y Francisco Carreres de Calatayud, constituyen el único caso en el que abuelo, hijo y nieto han sido miembros de número de la Real Academia de Cultura Valenciana. [Agradezco estos datos al personal de la Biblioteca Valenciana]. 
año 2000, la Generalitat Valenciana compró la Biblioteca Carreres ${ }^{77}$ a través de la Biblioteca Valenciana.

El otro impreso (2) —en formato francés, de 18,2 x 11,9 cm., y con la signatura CV/3712 —, pertenece a la denominada "Colección Valenciana" "78 que entró en los fondos de la Biblioteca Valenciana a finales de la década de 1980. Dicho impreso, se protege con unas guardas o solapas de papel, de color verde (de 19 x 13,2 cm.).

Ambos impresos con los textos de Las Siete Palabras, son iguales en su contenido. Pero en el segundo de ellos, el noveno verso de la Primera Palabra dice: Bien somos pecadosre, ofreciendo una errata que no aparece en el primer ejemplar.

Ambos impresos llevan el siguiente pie de imprenta:

“VALENCIA / EN LA IMPRENTA DE OLIVERES, ANTES DE ESTEVAN. / 1821.”.

He podido identificar la imprenta citada como correspondiente al editor Venancio Oliveres y Carbonell (*1798; †10.09.1875), quien era hijo de un impresor y librero de Tortosa, y que se estableció en Valencia con la intención de perfeccionarse en la bibliografía en casa de Mariano de Cabrerizo ${ }^{79}$. En 1821, Venancio Oliveres se casó en Valencia con la hija del también impresor José Estevan y Cervera (*1747c; †1820), quedando luego como sucesor de éste, según consta al pie de varios libros impresos —y entre ellos, el que contiene nuestras Las Siete Palabras — ${ }^{80}$.

77 Se trata de una colección reunida por Francisco Carreres Vallo, Salvador Carreres Zacarés y Francisco Carreres de Calatayud. Colección de manuscritos, monografías, publicaciones periódicas y grabados, dedicada a la temática valenciana con un importante número de folletos encuadernados. Además de 780 ejemplares de fondo antiguo, destacan las obras en valenciano, sobre literatura e historia de España, arte, fiestas y tradiciones, etc. Es una documentación fundamental para el estudio de la historia de la Comunidad Valenciana, en la que se unen clásicos de la historiografía, hojas volantes, recortes de prensa, piezas únicas o rarísimas, ediciones de bibliófilos, etc. [Agradezco esta información a María Ángeles Martínez Ques, Técnico Medio en acceso y obtención de documentos en la Biblioteca Valenciana].

78 Según $\mathrm{M}^{\mathrm{a}}$ Ángeles Martínez Ques, bajo este epígrafe se reúnen las obras ingresadas en la Biblioteca Valenciana, que son de autor, lugar de producción o temática valencianos. No forman parte de un legado ni han ingresado por depósito legal. Sus características tampoco permiten incluirlas en la colección de fondos antiguos y valiosos constituida por los libros de especial rareza, antigüedad y valor.

79 M. de Cabrerizo (*La Vilueña - Zaragoza—, 06.02.1785; †Valencia, 09.12.1868), se había establecido desde muy joven en Valencia, abriendo una librería en 1809; liberal, muy implicado en política, fue desterrado en 1826, pasando a Barcelona y luego a Francia (Perpignan, Toulouse, Burdeos y París), donde trabajó varios años, publicando luego en Valencia diversos trabajos (en 1830 amplió su negocio, estableciendo también una imprenta propia), entre los cuales, además de un calendario y diversos libros, constan algunas recopilaciones de canciones patrióticas, entre las que se contaba el célebre "Himno de Riego". Vid.: SERRANo y Morales, José Enrique: Reseña histórica en forma de diccionario de las imprentas que han existido en Valencia desde la introducción del arte tipográfico en España hasta el año 1868 con noticias bio-bibliográficas de los principales impresores. Valencia, Imprenta de F. Doménech, 1898-99, pp. 64-68. GALBIS LóPEZ, Vicente: “Cabrerizo y Bascuas, Mariano de", en Diccionario de la Música Española e Hispanoamericana. Madrid, SGAE, 1999, vol.2, p.845. Almela y VIVES, Francisco: El editor don Mariano de Cabrerizo. Valencia, CSIc, Instituto Nicolás Antonio, 1949.

80 Según J. E. Serrano, pese a la libertad política que se tenía en la época del Trienio Liberal (1820-1823), Venancio Oliveres fue una de las víctimas de la reacción absolutista de 1823 por haber reimpreso, en 1822, Teoría de una Constitución Política para España. Por un español., y las Máximas de Paul Henri Thiry, Barón de Holbach $(* 1723 ; \uparrow 1789)$. En virtud de la amnistía de la reina María Cristina de Borbón $(* 1806 ; † 1878)$ intentó establecer de nuevo su imprenta asociándose, primero con José de Orga y Piñana (*Valencia, 1800; $\dagger 1881)$ que, al disuadirle — Francisco Tadeo Calomarde $(* 1773 ; \dagger 1842)$ era ministro de Gracia y Justicia y aún regía la dura ley de la prensa-, hizo que formara sociedad con un valenciano que había conocido en Buenos Aires en la emigración, Luis Vicent, estableciendo en Valencia una fábrica de rayar el papel para libros de oficinas, comercio, etc. A la muerte de Oliveres heredó su establecimiento su hijo Ricardo Oliveres y Estevan (†17.02.1898). [Datos tomados de: SERRANO y Morales, José Enrique: Reseña histórica en forma de diccionario de las imprentas que han existido en Valencia desde la introducción del arte tipográfico en España hasta el año 1868 con noticias bio-bibliográficas de los principales impresores. Valencia, Imprenta de F. Doménech, 1898-99, pp. 380-381]. 
Por cuanto señalan ambos impresos, la noche del 19 de abril de 1821, día de Jueves Santo veinticinco años después de la versión que hiciera Joseph Haydn para voces solistas, coro y orquesta (Hob.XX/2) - se cantaron por primera vez en la Iglesia Parroquial de San Pedro Mártir y San Nicolás Obispo de la ciudad de Valencia, Las Siete Palabras. El entonces organista primero de la catedral valenciana, Francisco Xavier Cabo, fue quien ajustó el texto, de modo que se adecuara a la música compuesta por Joseph Haydn ${ }^{81}$.
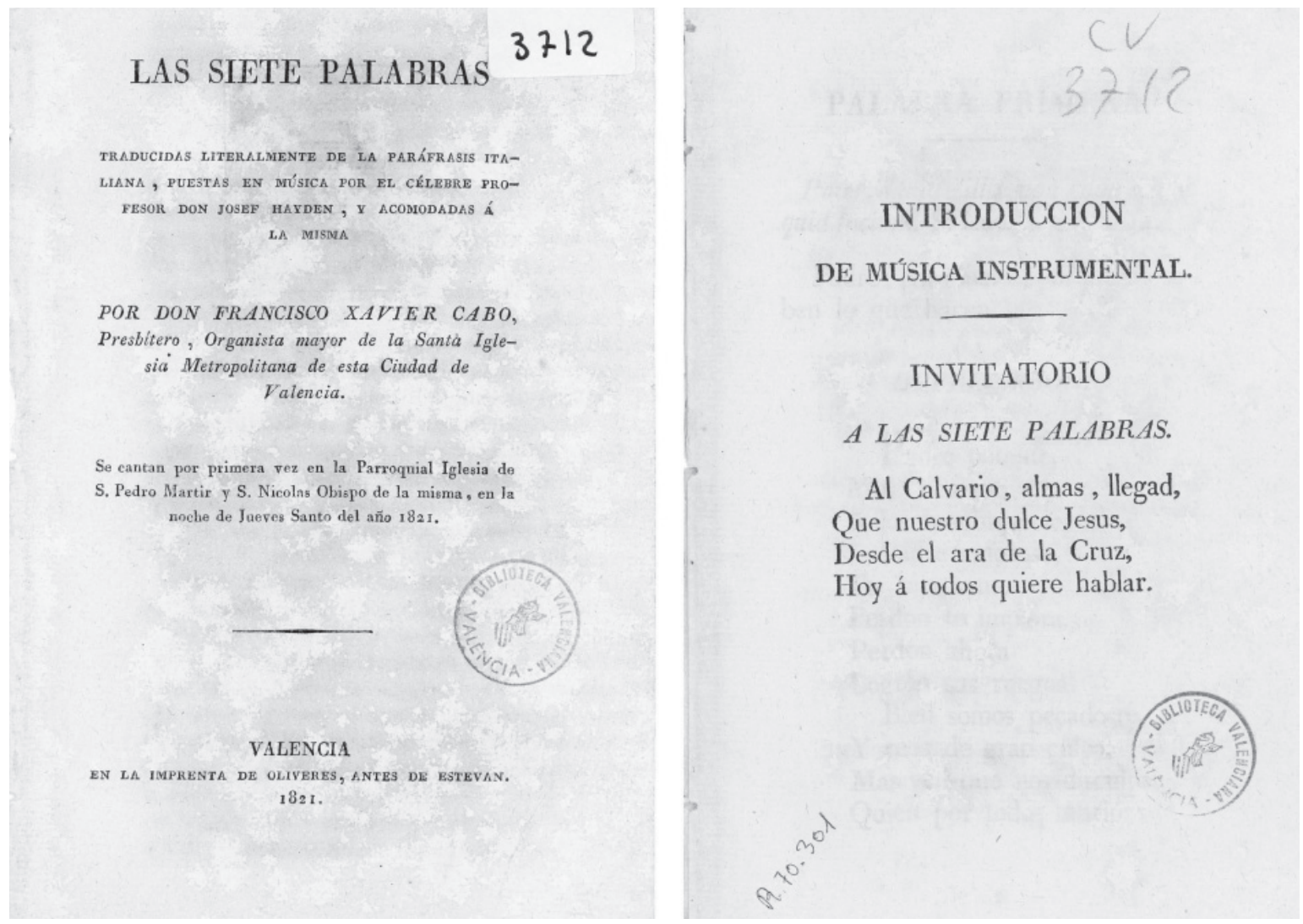

Figura 5: Impreso — portada y página 1- con la traducción de Las Siete Palabras por F. X. Cabo. Biblioteca Valenciana (Monasterio de San Miguel de los Reyes), signatura CV/3712

81 Francisco Javier Cabo Arnal (*Náquera —Valencia—, 24.05.1768; † Id., 21.11.1832), organista y maestro de capilla de la Catedral de Valencia, se había formado desde niño como infante de coro (con Francisco Morera y Rafael Anglés) en la misma catedral; poco después, ejerció como organista en la parroquial de Santa Catalina (1788) y como organista segundo - para cubrir ausenciasde la catedral (desde 1790), pasando ese mismo año a la organistía de Orihuela. Opositó a los magisterios de las catedrales de Valencia (1793), de Granada (1796) y de la Colegiata de Rubielos (Teruel), hasta que obtuvo el puesto de organista segundo en la Catedral de Valencia (1796) y, sucesivamente, los de organista primero interino (por jubilación del titular anterior, 1802), organista primero titular (1816), y maestro de capilla de la Catedral de Valencia (1830, sucediendo a Francisco Andreví). [Cfr.: Cuiment, José: "Cabo Arnal, Francisco", en Diccionario de la Música Española e Hispanoamericana. Madrid, SGAE, 1999, vol. 2, pp. 840-841. Vid. también: ID.: Orguens i Organistes Catedralicis de la Valencia del S. XIX. Valencia, Lo Rat Penat, 2002, pp. 144-158]. 


\section{PALABRA PRIMERA.}

Pater, dimitte illis; non enim sciunt quid faciunt. S. Luc. c. 23. v. 34.

Padre, perdónalos, porque no saben lo que bacen.

\section{DEPRECACION}

Padre potente,

Mira benigno

A los hombres ciegos.

Padre amoroso,

Tu hijo santo

Perdon te implora.

Perdon ahora

Logren sus ruegos.

Bien somos pecadosre,

$\mathrm{Y}$ reos de gran culpa;

Mas ved que nos disculpa

Quien por todos murió:
Dios que padeció

Por nuestro amor.

Mis culpas lava,

Padre amoroso,

Sedme piadoso,

Escucha al Hijo.

Ob! Padre, ob! Padre,

Perdon alcance el Hijo.

\section{PALABRA SEGUNDA.}

Amen dico tibi: Hodie mecum eris in Paradyso. S. Luc, c. 23. v. 43.

En verdad te digo: Hoy serás conmigo en el Paraiso.

\section{DEPRECACION.}

Tú de gracia eres la fuente, Oh! divino mediador;

Dice y ruega el penitente:

Figura 6: Páginas 3 y 4. [Pág. 2, en blanco]. Íbid., signatura CV/3712

De mi, puesto ya en tu reino, Ay! acuérdate, oh! Señor.

Tú le das palabra en prenda: Hoy conmigo serás en el Paraiso.

Tú de gracia eres la fuente,

$\mathrm{Oh}$ ! divino mediador,

Dios, Señor y Redentor.

Llorosos aqui estamos,

Ante tu cruz clamamos,

Dulce Padre, aqui nos tienes,

Dios, Señor y Redentor.

Ah! En el punto del morir

Merezcamos de tu boca oir:

Hoy conmigo serás en el Paraiso.

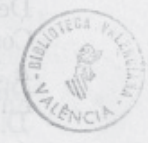

\section{PALABRA TERCERA.}

Mulier, ecce filius tuus :.... Ecce mater tua. S. Joann. c. 19. v. 26.27.

Muger, he ahi tu hijo:.... He ahí tu madre.

\section{DEPRECACION.}

Virgen madre sin consuelo! ¿Sollozando, suspirando!

¡Virgen madre, santa, sin consuelo! El suplicio vil nefando,

El suplicio de Jesus,

Tu alma siente sin consuelo

Junto á la cruz, suspirando.

En momento tan cruel,

De piedad tú conmovida,

Como á hijo das cabida

A Juan, discípulo fiel,

En medio del dolor.

Figura 7: Páginas 5 y 6. Íbid., signatura CV/3712 

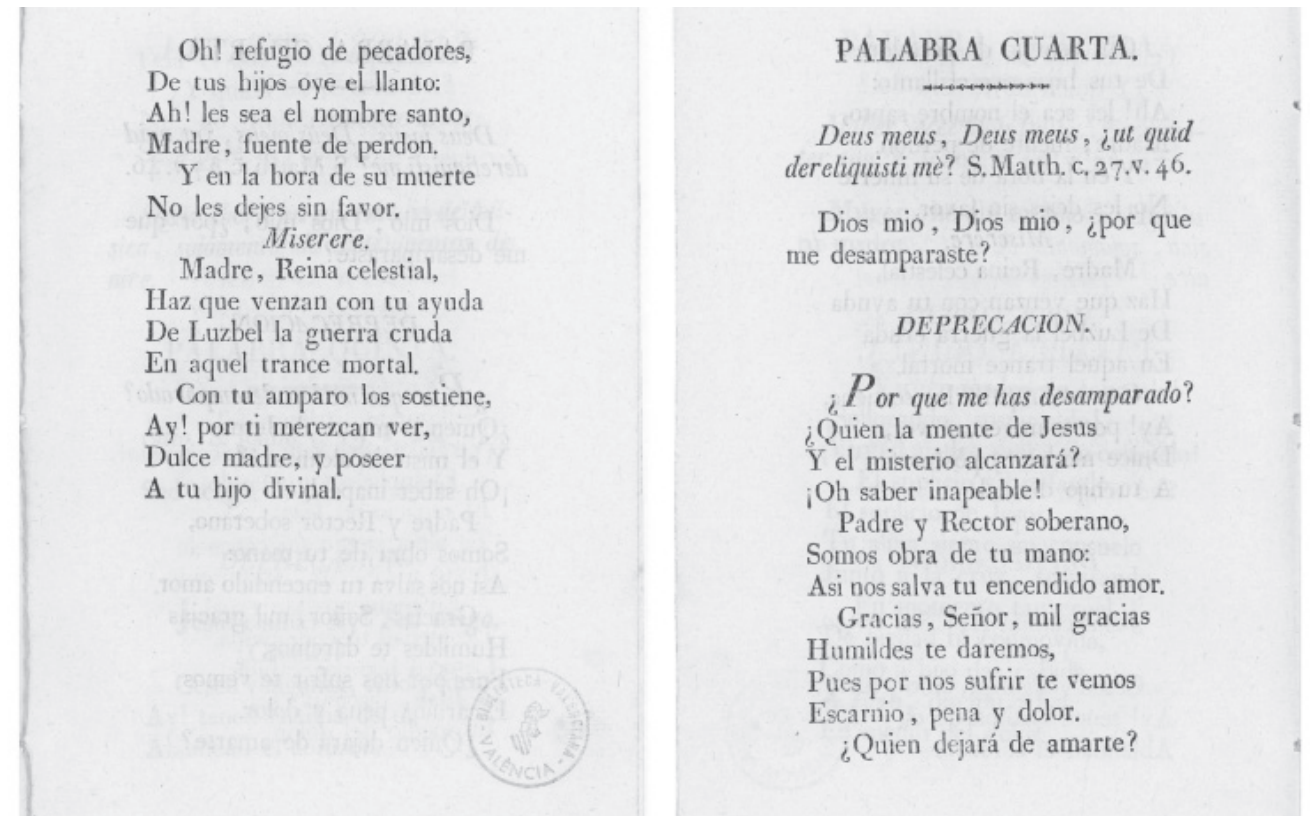

Figura 8: Páginas 7 y 8. Íbid., signatura CV/3712
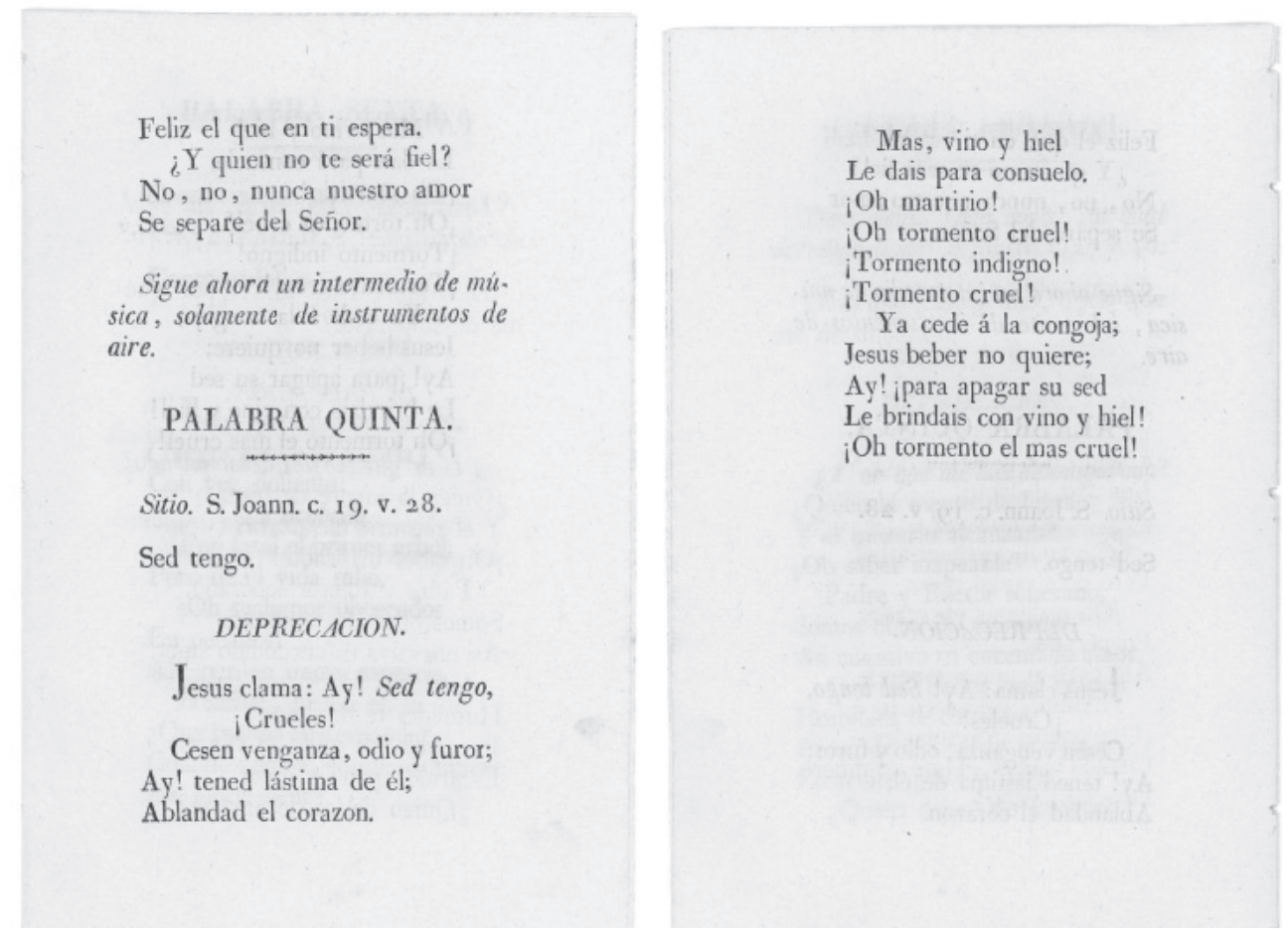

Figura 9: Páginas 9 y 10. Íbid., signatura CV/3712 
PALABRA SEXTA.

Consummatum est. S. Joann. c. I 9. v. 3 o.

Consumado es.

$$
\text { DEPRECACION. }
$$

Jesus grita puesto en cruz (Negra noche le cubria)

Con voz doliente:

$$
\text { Es acabado. }
$$

Fue fatal el primer arbol; Pero de él vida salió.

¡Oh malignos obcecados En pecados!

Ah! perdon nunca espereis.

Hombre, piensa en ti. ¿Que podrás tú responder Cuando vuelva, el que asi muere, De gloria lleno?

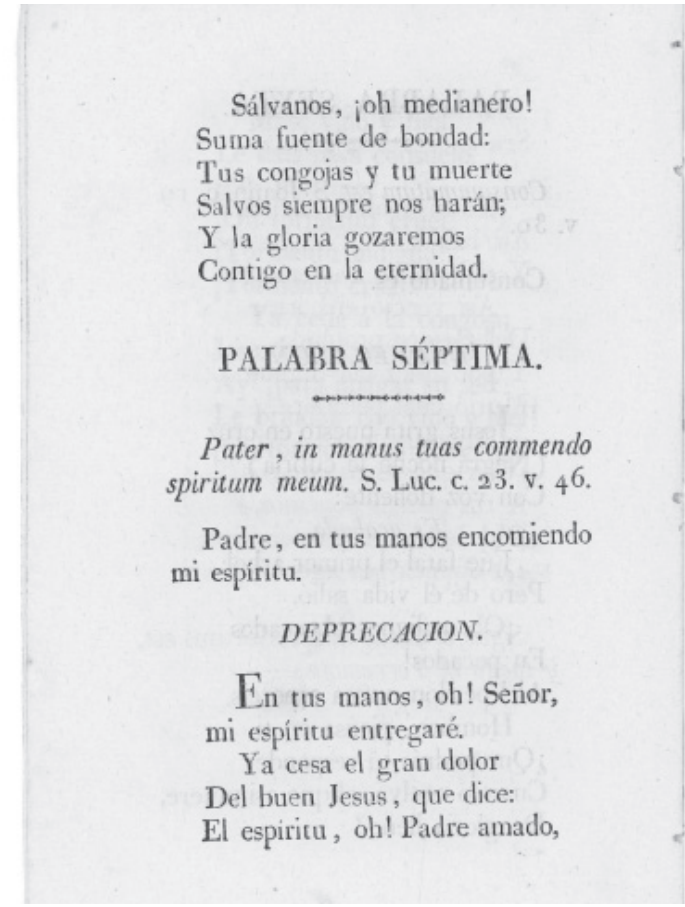

Figura 10: Páginas 11 y 12. Íbid., signatura CV/3712
A ti sea encomendado;

Sea encomendado á ti.

$$
\text { Si, }
$$

En tus manos, oh! Señor.

Asi habló,

Y el hombre Dios murió.

Asi venció el horror

Del tártaro profundo,

$\mathrm{Y}$ por amor del mundo

Murió cual pecador.

Aquesta nueva vida

¿Con que te pagaremos?

A tus plantas ponemos,

Oh! Jesus, nuestro corazon;

La ofrenda sea agradable á ti.

Sigue el Credo hasta Mortuus est, $y$ luego el Terremoto.

\section{EL TERREMOTO.}

El hombre Dios murió;

Resuenen las hondas cavernas.

Tú tiembla, ó Gólgota,

Caigan tus altas cimas.

Ah! huye, ó sol, anochece este dia:

Hiéndase la tierra malvada,

De impíos vil morada.

Oh! sepulcros, abríos,

$\mathrm{Y}$ de su obscuro seno

Salid, padres antiguos:

La tierra que os cubrió,

De sangre se empapó.

Figura 11: Páginas 13 y 14. Íbid., signatura CV/3712 
Como bien podrá el lector comprobar, se trata de unas meditaciones distintas, es decir, de un texto diferente - excepto el InVITATORIO-, a las utilizadas en Zaragoza por Francisco Javier García Fajer, el maestro Españoleto ${ }^{82}$. Seguramente, los textos zaragozanos, también en traducción al castellano, —y dado que el Españoleto falleció en 1809—, sean anteriores en el tiempo a los utilizados en Valencia, de $1821^{83}$.

Una vez repasada la utilización de los textos en las fuentes valencianas, es preciso señalar que, por su parte, el catálogo temático de Anthony van Hoboken no menciona los documentos valencianos que hemos analizado, como tampoco otras copias manuscritas que se han conservado en España y que he podido localizar, ubicadas en los archivos de las Catedrales de Zaragoza, la Colegiata de Cervera, y las catedrales de Gerona, Lérida, Salamanca, Santiago de Compostela, y Santo Domingo de la Calzada ${ }^{84}$.

82 Vid.: González Valle, José Vicente: [Francisco Javier García:] Siete Palabras de Cristo en la Cruz. Barcelona, Consejo Superior de Investigaciones Científicas, Institución "Milà i Fontanals”, Departamento de Musicología, 2000.

83 El texto utilizado para la versión precedente, en Zaragoza, es el siguiente: "[Introducción:] /Al calvario almas llegad, / que nuestro dulce Jesús, / desde el ara de la cruz, / hoy a todos quiere hablar. / [1 ${ }^{a}$ Palabra:] [Pater dimitte illis, quid nesciunt, quid faciunt. (Lucas 23,3)] / Pues que fui vuestro enemigo, / mi Jesús, como confieso, / rogad por mi, pues con eso, / seguro el perdón consigo, / seguro el perdón os pido. / Cuando loco te ofendí, / no supe lo que me hacía, / ay Jesús del alma mía, / rogad al Padre por mí. / [ 2 ${ }^{a}$ Palabra:] [Hodie mecum eris in Paradiso. (Lucas 23,43)] / Reverente el buen ladrón, / imploró vuestras piedades, / yo también de mis maldades / os pido, Señor, perdón. / Si al ladrón arrepentido / dais lugar allá en el cielo, / ya yo también sin recelo / la gloria, mi Dueño, os pido. / [3 ${ }^{a}$ Palabra:] [Mulier, ecce filius tuus. (Juan 19,26)] / Jesús en su testamento / a la Virgen hoy nos da. / Oh María, quién podrá / explicar tu sentimiento. / Hijo vuestro quiero ser, / sed vos mi madre, Señora, / que os prometo desde ahora / finamente obedecer. / [ $\mathbf{4}^{a}$ Palabra:] [Deus meus, Deus meus, ut quid dereliquisti me? (Salmo 22,2. Mateo 27,46. Marcos 15,34)] / Desamparado se ve / de su padre el hijo amado. / Ah, maldito mi pecado, / que de esto la causa fue. / Quien quisiere consolar / a Jesús en su tormento, / diga de veras, Señor, / me pesa, no mas pecar. / [5a Palabra:] [Sitio. (Juan 19,28)] / Sed dice Cristo que tiene. / Mas si quieres mitigar / la sed que le llega a ahogar, / darle lágrimas conviene. / La hiel que brinda el ministro, / si la gusta no la bebe. / ¿Cómo quieres tu que pruebe / la hiel de tu culpa Cristo? / [6 ${ }^{a}$ Palabra:] [Consummatum est. (Juan 19,30)] / Con voz quebrada mi Dios / habla ya muy desmayado, / y dice, que del pecado / la rendición consumó. / Ya Jesús se ve expirar, / ya Jesús se ve morir. / ¿Quién, pues, no llega a rendir / la vida con el pesar? / [7 ${ }^{a}$ Palabra:] [In manus tuas, Domine, commendo spiritum meum. (Lucas 23,46)] / A su Eterno Padre ya / su espíritu recomienda. / Si tu vida no se enmienda, / ¿en que manos parará? / En las tuyas, desde ahora, / mi alma entrego, Jesús mío. / No me mires con desvío / en aquella hora fatal. / Si tu vida no se enmienda, / ¿en que manos parará?”. [Vid.: González Valle, José Vicente: [Francisco Javier García Fajer:] Siete Palabras de Cristo..., op. cit., pp. 8-10].

84 El catálogo de Hoboken (op. cit.) menciona copias en Alemania (en ocho archivos y bibliotecas), Austria (siete), Italia (cuatro), España (dos), Eslovaquia (una), Estados Unidos (una), Francia (una), Hungría (una), y Suecia (una). Para las copias españolas citadas, véase: Civil I CASTELlví: "La capilla de música de la catedral de Gerona (siglo XVIII", en Anales del Instituto de Estudios Gerundenses, 29 (1968-1969), pp. 131-188. López Calo, José: Catálogo Musical del Archivo de la Santa Iglesia Catedral de Santiago. Cuenca, Instituto de Música Religiosa, 1972, p. 315 [partichelas manuscritas en copia de 1904]. García Fraile, Dámaso: Catálogo del Archivo de Música de la Catedral de Salamanca. Cuenca, Instituto de Música Religiosa, Diputación Provincial de Cuenca, 1981, p. 214. Calle González, Benjamín: Catálogo de Música y documentos musicales del Archivo de la Catedral de Lérida. Lleida, Dilagro, 1984, p. 54. López Calo, José: La Música en la Catedral de Santo Domingo de la Calzada. Logroño, Gobierno de la Rioja, Consejería de Educación, Cultura y Deportes, 1988, p 342. RifÉ I SANTALó, Jordi: "Notas sobre el fons musical de l'arxiu de la catedral de Girona", en Actes del I Congrés Català de la Música. Barcelona, 1994. -Inventario Archivo de Música Colegiata de Cervera (Lérida) [Inédito; agradezco la información al Dr. Antonio Ezquerro]. En Zaragoza, se conservan dos copias de esta obra; la primera, con la signatura E: Zac, D-351/4143, se trata de una partitura impresa por Bonifacio [Sanmartín de] Eslava en Madrid en el siglo XIX, y recoge una versión cantada con texto en italiano (arreglo de S. Neukomm) de "Las / Siete Palabras / de N.S.J. / para canto / y acompañamiento de piano ú organo / por S. Neukomm. / Letra italiana / música de Joseph Haydn"; se anota para S, A, T, B y piano, comenzando en Re menor y compás de compasillo, con el texto "Pater! dimitte illis"; [por su parte, el catálogo de Hoboken recoge hasta tres ediciones de esta composición, cuya versión para piano corrió a cargo del mencionado Sigismund Neukomm -discípulo de Haydn-, a saber: 1) Carli, $n^{\circ}$ de plancha 2190, 1819+; 2) Girod, 1855c; y 3) Mollo, n ${ }^{\circ}$ de plancha 1075, 1804+?]. La segunda fuente zaragozana, E: Zac, D-142/1177, recoge texto latino y castellano y se inicia con las palabras "Mulier, ecce filius tuus". Se encuentra además 


\section{Missa in Tempore Belli, "Paukenmesse"}

Joseph Haydn compuso en 1796 la Missa in tempore belli "Paukenmesse" (conocida en castellano como "Misa en tiempos de guerra", o más comúnmente, "Misa del timbal") (Hob.XXII:9) en Do Mayor, obra que puede consultarse en el tomo de la edición completa de sus obras, XXIII/2 [pp.89-165], publicado por el Joseph Haydn-Institut de Colonia bajo la dirección de Jens Peter Larsen, editado por H. C. Robbins Landon junto con Karl Heinz Füssl y Christa Landon e impreso en 1958 en la editorial G. Henle de Munich. No se ha publicado todavía el análisis sobre dicha composición o informe crítico ("Kritischer Bericht").

Por su parte, en el archivo de la Catedral de Orihuela (Alicante), se encuentran dos borradores bajo la signatura 54/24:

"Borrador /a los Kyrie y Gloria / con toda Orquesta / del Mtro. Haydn y / Borrador / al Credo, Sanctus, Bend y Agnus / con toda Orquesta / del Mtro. Haydn.”

Ambos borradores forman parte de un tomo que incluye otras obras, a saber: el Requiem de Wolfgang Amadeus Mozart y un Magníficat á 4. de Difuntos, que consta como anónimo en la fuente ${ }^{85}$, y tras éste último, los dos borradores mencionados de la Misa de Joseph Haydn. Todo ello encuadernado con tapas de cartón con un lomo marrón que lleva inscrito en letras doradas: "MOZART / REQUIEM". El manuscrito —que mide 21,1 x 30,9 cm. - debió de correr la misma suerte que el correspondiente a la Gran Misa para solo de órgano de Joseph Haydn descrita al principio de este artículo. En la primera hoja dice: "Libro $2^{\circ}$ ". En el margen superior derecho de la primera hoja de papel pautado, figura la siguiente inscripción:

"El Servicio de Defensa de Patrimonio Artístico Nacional deposita en la Catedral de Orihuela este manuscrito de música religiosa. Alicante 20 Abril 1940”.

Como en el caso anteriormente analizado, también parece que este documento fue reescrito donde en un principio ponía "Colegiata de Alicante", quedando finalmente "Catedral de Orihuela".

Seguidamente hay una firma. En el sello quedó estampado:

en este mismo archivo otra versión anónima e incompleta de Las Siete Palabras, del siglo XIX, acaso atribuible al maestro de Rohrau (E: Zac, D-269/2388), que comienza en ReM y compás mayor con las palabras "Mulier, ecce filius tuus", y que alterna las palabras de Jesús en latín, a fabordón, con el texto en vulgar. [Agradezco las informaciones sobre las fuentes de Zaragoza al Dr. Antonio Ezquerro]. Por otro lado, se conserva en la Catedral de Mondoñedo una versión orquestal de esta obra: $c f r$. Trillo, Joan; y Villanueva, Carlos: El Archivo de Música de la Catedral de Mondoñedo. Salamanca, Publicaciones de Estudios Mindonienses, $\mathrm{n}^{\circ}$ X, Imprenta Kadmos, 1993, p. 373: obra con la signatura "47/6" y no de registro "1505". Entretanto, a fecha de hoy no es posible saber si el Joseph Haydn-Institut de Colonia menciona copias manuscritas conservadas en España, dado que no se ha publicado todavía el estudio crítico (o "Kritischer Bericht") sobre esta composición.

85 En la portada de este Requiem, se anota una firma, en su margen inferior derecho: "De Vicente Clavéa" [rubricado]; este nombre, podría identificarse con el propietario o copista de esta obra, y acaso, por extensión, del "Magnificat de difuntos" que le acompaña. 


\section{“Recuperación Patrimonio Artístico Nacional - Servicio Militar”.}

La música se extiende del folio 1 al 58 -el primer borrador, del folio 1 al 22, y el segundo borrador, del folio 23 al 58-, encontrándose ambos borradores separados por un folio pautado sin escribir. Como ya vimos al mencionar el Stabat Mater, también en esta Misa la tinta utilizada ha perforado los papeles, de manera que muchos pasajes son difícilmente legibles. Sin indicación expresa de fecha alguna, la datación de esta fuente podría fijarse hacia el último cuarto del siglo XIX (entre 1875 y 1900, aproximadamente), lo que vendría a ratificar la expresión recogida, "con toda Orquesta". El reparto de las voces y de los instrumentos se anota en castellano, con alguna pequeña influencia italiana.

Al cotejar estas fuentes oriolanas con el tomo de la edición completa de las obras de Joseph Haydn, se puede apreciar que en ellas falta el oboe segundo, dos clarinetes, timbales y el órgano, mientras que se añaden una flauta ${ }^{86}$ y un "baxo". Llama poderosamente la atención el hecho de que, tratándose de una obra que presenta una infrecuente escritura para timbales en el Agnus Dei (instrumento que a mediados del siglo XIX sirvió para identificar con su nombre la composición), éstos no se hayan transcrito en las copias alicantinas, acaso por carecerse de dicho instrumento en la capilla catedralicia de Orihuela en aquellas fechas (?).

De otro lado, el Gloria de esta Misa se divide en tres movimientos, Vivace / Adagio / Allegro, cuyo movimiento central se anota en la tonalidad contrastante de La Mayor, al mismo tiempo que introduce a los solistas — se trata de un aria para Bajo con el solo de un violonchelo-. Curiosamente, y a manera de contrafactum del Qui tollis del citado Gloria de la Paukenmesse de Joseph Haydn (es decir, de su segundo movimiento mencionado, Adagio), se halla una copia manuscrita —únicamente de este segundo movimiento- en el archivo del Real Colegio-Seminario de Corpus Christi de Valencia, bajo la signatura $\mathrm{H} 8 / 6$, aunque en el documento valenciano lleva otro texto aplicado, $O$ fons pietatis ${ }^{87}$ ("Oh fuente de piedad").

La fuente documental valenciana del archivo de la Iglesia del Patriarca, incluye una cubierta de papel — la cual sirve para recoger todas las copias manuscritas_-, con el siguiente título caligrafiado:

"O fons pietatis / Motete á solo y coro. / Mtro. J. Haydn. / Colegio de Corpus Christi / Valencia".

86 Según D. Wyn Jones: "The mass was scored for an orchestra of two oboes, two clarinets, two bassoons, two horns, two trumpets, timpani, strings, and organ; Haydn later expanded the contribution of the clarinets and added a part for one flute". [La Misa se instrumenta para una orquesta con dos oboes, dos clarinetes, dos fagotes, dos trompas, dos trompetas, timbales, instrumentos de cuerda y órgano; más tarde Haydn amplió la contribución de los clarinetes y añadió una parte para flauta]. (WYN Jones, David: Oxford Composer Companions: Haydn. Nueva York, Oxford University Press, 2002, p. 241).

87 Agradezco sus indicaciones en este sentido al Dr. Robert von Zahn, del Joseph Haydn-Institut de Colonia, en su carta del 20 de febrero de 2002. 
El manuscrito, en formato italiano o apaisado - excepto la parte para el "Barítono à Solo", en formato francés o vertical, 32 x $23 \mathrm{~cm}$.- , se compone de diversas partichelas de 23’ 6 x $32 \mathrm{~cm}$., en cada una de las cuales se puso el tipo de voz o instrumento, el género musical y el nombre del autor. Así por ejemplo, en la primera página de la reducción de la partitura, se lee:

"Mottete del Miro . J. Haydn. (Guión para dirigir.)".

Además de dicho "guión para dirigir" (que hace las veces de reducción de la partitura para el director $)^{88}$, se conservan las siguientes partichelas: "Barítono á Solo"; "Tiples" "89; "Contraltos" (duplicado); "Tenores" (duplicado); "Bajos de coro" (duplicado); "Bajos de 2do coro"; "Violoncello [y] Contrabajo" $" 90$ [ambos instrumentos anotados en pautas independientes, abrazadas, por parejas, con una llave, en un único sistema, a razón de cinco sistemas por página] ${ }^{91}$. Estas partes manuscritas del O fons pietatis valenciano, modifican los compases 193 a 195 — la cadencia final— de la edición realizada por el Joseph Haydn-Institut de Colonia del Qui tollis del Gloria (Adagio) de la Paukenmesse haydniana, hasta el punto de concluir con una cadencia plagal, de suerte que se adultera la música del original, prolongándola: las copias manuscritas de la fuente valenciana presentan dos compases de más.

Excepto el "Guión para dirigir" (i.e., la partitura reducida) y las partichelas para el "Barítono à Solo" (que indica en su éxplicit una duración de "73. comp.") y para los "Tiples", todas las demás partichelas, llevan fecha de 1891, siendo entonces el maestro de capilla del Real Colegio-Seminario de Corpus Christi, Lamberto Plasencia Valls (*Benaguacil -Valencia-, 18.09.1809; †Valencia, 18.10.1893 $)^{92}$. Se trata, por tanto, de copias realizadas noventa y cinco años más tarde de la composición autógrafa del compositor de Rohrau.

88 Se anota en sistemas de tres pautas, a razón de: la primera pauta, para la "Voz" y la segunda y tercera pautas para el "Orgo", realizado. Al hilo de la escritura, se anota en cada pauta las sucesivas intervenciones, de las diferentes partes vocales o instrumentales, y así, en la pauta para "Voz", se escribe en ocasiones "Bajo solo", "Coros" (anotado en acordes), "Solo", o "Coro"; mientras que en las dos pautas para el órgano ("Espresivo"), se anota sucesivamente la intervención del "Violoncello solo", y del "Violon". Por su lado, el tempo de esta composición, se anota, como en el original haydniano, "Adagio", únicamente en las partichelas, mientras que se anota en esta reducción como "Tiempo lento, siguiendo à las partes obligadas".

89 Las partichelas de "Barítono á Solo" y "Tiples" son las únicas que llevan una indicación que se corresponde con una breve y momentánea modificación de tempo, al anotar "allarg" en el compás 70.

90 El copista escribe las notas de adorno del contrabajo con una barra más —en fusas- que las propias del violonchelo —en semicorcheas - (compás 70). Todo parecer indicar en este sentido, que el compositor/copista, era bien consciente de que cuanto más grave es un instrumento, tiene mayor resonancia y menor capacidad de reacción, por lo que debe tocar más corto para unificarse con el resto de instrumentos: un contrabajo, de cuerdas muy gruesas, "tarda" un poquito más en reaccionar —-la diferencia de ataque es mínima, pero la hay- que, como por ejemplo en el presente caso, un violonchelo. [Lo que nos daría a entender que se trataba de buenos orquestadores y conocedores de los instrumentos que se manejaban].

91 La reducción para el director anota en cada cara tres sistemas con música, más una pauta adicional sin anotar; por su lado, las partes vocales anotan diez pentagramas, mientras que la partichela para el "Violoncello [y] Contrabajo" traza cinco sistemas en cada cara.

92 Sobre este músico, y su sobrino Juan Bautista, asimismo compositor (véase la nota 28), vid: GALBIS LóPEZ, Vicente, y López CARranza, M. ${ }^{a}$ Cruz: "Plasencia (II)", en Diccionario de la Música Española e Hispanoamericana. Madrid, sGAE, 2001, vol. 8, pp. 855-857. [No obstante, todos los papeles conservados parecen estar copiados por una misma y única mano]. 
Por otro lado, esta misma composición, y con este mismo texto alternativo en latín, igual al que encontramos en Valencia (O fons pietatis), donde aparece catalogada en el año 1909, se halla en partitura publicada en París en 1842 por el editor Canaux, dentro de la colección editorial titulada $L a$ Lyre Sacrée, y con número de plancha "C. C. 869"93. Presenta un formato vertical, [pp. 1-11], de 35,2 x 27,4 cm., y en su portada se imprime el siguiente título, al que se añade el sello ovalado entintado, de caucho, del almacén editorial correspondiente:

“O FONS PIETATIS / Pour Basse, Solo et Choeur / A QUATRE VOIX / Avec accomp ${ }^{t}$ d'Orgue

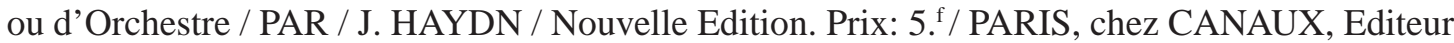
de Musique Religieuse. / Rue ${ }^{\text {te }}$ Appoline, 15.”.

Según la armadura de la clave inicial de este impreso $O$ fons pietatis!, el reparto sugerido es para: "Violon 1", "Violon 2"”, "Alto", "Fagotti", "Violon"elle", "Contre-Bsse", y "Orgue". A medida que avanza la composición, se añaden instrumentos, tales como "Cor in A", "Flute", "Haut-bois", y el coro, concebido para "Soprano", "Alto", "Tenore" y "Basse"94.

\section{Ave María}

Debe tratarse de una transcripción de la canción a cuatro voces de Joseph Haydn titulada Der Greis ("El anciano") (Hob. XXVc:5), con texto de Johann Wilhelm Ludwig Gleim (*1719; †1803). Según parece, Joseph Haydn no habría tenido nada que ver con esta transcripción ${ }^{95}$.

La obra original puede consultarse en el tomo de la edición completa de sus obras, XXX [pp. 2933], publicado por el Joseph Haydn-Institut de Colonia bajo la dirección de Jens Peter Larsen, editado por Paul Mies e impreso en 1958 en la editorial G. Henle de Munich.

En el archivo de la Catedral de Valencia, y con la signatura 153/6, se encuentra no obstante una copia manuscrita de esta misma partitura (de 21,7 x 31,3 cm.), pero no con su texto original ("El anciano"), sino en su modalidad con texto "a lo divino". Su título dice:

"Ave Maria a 4. ${ }^{\circ}$ y 8. de Haydn."

93 Agradezco la datación de este impreso a la profesora Anik Devriès-Lesure, en su carta del 26 de enero de 2005.

94 Curiosamente, en el Archivo de Música de las Catedrales de Zaragoza se conserva también un corpus documental (E: Zac, D-304/2987), anónimo aunque atribuido a Joseph Haydn, el cual reúne partitura y partichelas, tanto impresos como manuscritos, de este mismo motete "O fons pietatis" en La Mayor, y con su inicio en compás de compasillo. Dicho impreso trae la siguiente información: "Colombier, editor, rue Vivienne 6, Paris" (colección: "La Lyre Sacrée"). La parte para el órgano está cifrada, y se conservan tres ejemplares manuscritos de las partes para cada voz. (Agradezco la información al Dr. Antonio Ezquerro). de 2002.

95 Agradezco la información al Dr. Robert von Zahn, del Joseph Haydn-Institut de Colonia en su carta del 20 de febrero 
Si se hubiera de aventurar una datación para esta fuente, podríamos decir que la copia manuscrita, tanto de la partitura como de las partichelas — estas últimas, todas de la misma mano_-, podría haber sido realizada, por distintos copistas, aproximadamente entre 1880 y 1900.

El texto al que Joseph Haydn puso música es el siguiente ${ }^{96}$ :

"Hin ist alle meine Kraft,

Alt und schwach bin ich,

Wenig nur erquicket mich,

Scherz und Rebensaft.

Hin ist alle meine Zeit,

Meiner Wangen Roth ist hinweg geflohn,

Der Todt klopft an meiner Thür,

Unerschröckt mach ich ihm auf.

Himmel! Habe Danck,

Ein harmonischer Gesang

War mein Lebenslauf"97.

Por su parte, el texto de la copia manuscrita que se custodia en el archivo de la Catedral de Valencia es litúrgico, tratándose de un Ave María:

Ave Maria, gratia plena, Dominus tecum, benedicta tu in mulieribus et benedictus fructus ventris tui Iesus. Sancta Maria, Mater Dei ora pro nobis, peccatoribus, nunc et in hora mortis nostrae. Amen. ${ }^{98}$.

En cuanto a la instrumentación en la fuente valenciana de carácter religioso (copiada hacia finales del siglo XIX y anotada en la tonalidad de La Mayor), y en relación al original profano, se pueden constatar algunas variantes, a saber: la edición del Joseph Haydn-Institut es para Soprano, Contralto, Tenor, Bajo, cembalo y pianoforte, mientras que la copia manuscrita valenciana se concibe para coro favorito (solistas) y coro de ripieno (es decir, “a 4 y a 8”), más el órgano, que aparece realizado.

Se conservan, además de la partitura, algunas partichelas (asimismo de 21,7 x 31,3 cm.), para las voces ("Tiple", "Alto", "Tenor” y "Bajo”), y para la parte de órgano (realizado; en dos folios, cuya primera página sirve de portada y anota “Ave Maria / Hayden”) $)^{99}$.

96 Véase: Robbins Landon, Howard Chandler: Haydn, Chronicle and Works. Vol. IV: The years of "The Creation", 17961800. Londres, Thames and Hudson, 1977, nota al pie 1, p. 192.

97 "Toda mi fuerza se ha desvanecido, / Me encuentro viejo y débil, / Pocas cosas me fortalecen, / Broma y vino. / Todo mi tiempo se ha desvanecido, / El rubor de mis mejillas se ha marchado, / La muerte llama a mi puerta, / Sin miedo la recibo. / ¡Cielo! Te doy gracias, / Un canto armónico / fue mi vida".

98 "Dios te salve, María; llena eres de gracia; el Señor es contigo; bendita Tú entre las mujeres, y bendito es el fruto de tu vientre, Jesús. Santa María, Madre de Dios, ruega por nosotros, pecadores, ahora y en la hora de nuestra muerte. Amén".

99 Se conserva en el Archivo de Música de las Catedrales de Zaragoza una partitura impresa de esta misma composición: E: Zac, D-303/2973; el impreso, a cargo de Regnier Canaux, París, lleva sello entintado de caucho de "R. de Mezièrs, Paris", 


\section{Insanae et vanae curae}

Se trata en este caso de un contrafactum, de autor desconocido, originado a partir de la revisión que Joseph Haydn hizo en 1784 de su propio oratorio Il Ritorno di Tobia (Hob.XXI:1), con vistas a una representación en Viena, para la cual el compositor añadió unos Coros, entre los cuales se encontraba la parte de Coro titulada Svanisce in un momento de i malfattor la speme ("Se desvanece en un momento la esperanza de los malhechores"). Unos años más tarde, probablemente en 1797, y para una representación en Eisenstadt, surgió de este último Coro citado una nueva obra autónoma, que utilizaba el nuevo texto Insanae et vanae curae ("Insanas y vanas preocupaciones").

Muy posiblemente, y dado que se tiene noticia de esta obra a través del sirviente y copista de Joseph Haydn, Johann Elssler $(* 03.05 .1769 ; \nmid 12.01 .1843)$, podría inferirse que fuera el propio Joseph Haydn el autor de este contrafactum ${ }^{100}$. En todo caso, este motete puede consultarse en el segundo tomo de la edición completa de sus obras, XXVIII/1 ${ }^{\mathrm{II}}$, publicado por el Joseph HaydnInstitut de Colonia bajo la dirección de Georg Feder, editado por Ernst Fritz Schmid e impreso en 1963 en la editorial G. Henle de Munich como Coro [13c.], pp.431-482.

En el archivo del Real Colegio-Seminario de Corpus Christi, se conserva un ejemplar impreso de este motete Insanae et vanae curae, en Re menor, sin signatura, aunque con número de registro 2.583. Se trata de una partitura de 35,2 x 27,4 cm., publicada en París en 1827 por Alexandre Choron, según se desprende del número de plancha "A. C. 70". No obstante, la atribución a Nicou-Choron et Canaux, y la dirección postal, indicarían una datación correspondiente al año $1842^{101}$, cuando se habría incluido en la colección La Lyre Sacrée (con numeración dentro de la colección, pp.133-143, y paginación individual del impreso, pp.1-11), en cuya primera página se lee:

y pertenece a la colección editorial "Repertoire des Paroisses de Paris / Choix de Motets [...]", incluyendo listas del repertorio musical religioso de las citadas parroquias de París. (Agradezco el dato al Dr. Antonio Ezquerro).

100 Agradezco nuevamente esta información al Dr. Robert von Zahn (escrito del 25 de junio de 2004).

101 La profesora Anik Devriès-Lesure, a quien nuevamente agradezco sus datos (carta del 11 de febrero de 2005), me informa amablemente de que "la hija de Alexandre Choron $(* 21.10 .1771 ; \nmid 29.06 .1834)$, Alexandrine, se había casado con Stephano Nicou, y en asociación con su marido había continuado el comercio de edición de música religiosa. NC significa NicouChoron. Canaux retomó el fondo en 1837, pero entre 1834 y 1837 Canaux estuvo asociado a Nicou". A partir de tales afirmaciones, podríamos colegir lo siguiente: que en 1827, Alexandre Choron (padre de Alexandrine y suegro de Stephano Nicou, matrimonio que se darían a conocer más tarde en el terreno editorial de música como "Nicou-Choron") hubiera impreso esta composición, que más tarde habría pasado a ser propiedad de su hija y yerno, es decir, de Nicou-Choron, quienes (o más propiamente, únicamente el esposo, Stephano Nicou), entre 1834 y 1837, se habrían asociado con Canaux; de donde la aparición de tales nombres y dirección postal en el pie del impreso. No obstante, y comoquiera que desde 1837, se hizo cargo del negocio que antes era del matrimonio, su socio, Canaux (que habría mantenido los anteriores números de plancha, al menos hasta el año 1842), tal vez por ello, la profesora Devriès adjudica una datación del año 1842 para este impreso en concreto. 


\section{"INSANAE ET VANAE CURAE / MOTET D'HAYDN. /}

Arrangé pour le Forte Piano par ZULEHNER. ${ }^{102 /}$

À Paris, au Magazín de musique d'Eglise et d'Education musicale, ${ }^{103} /$ NICOU-CHORON et CANAUX. Rue S. te APPOLINE 15 /

Prix $5^{\mathrm{f}} /$

No44 $4546 /$

Rel: $\quad$ A. C. $70 ”$.

De esta misma composición, he podido localizar un ejemplar (de once páginas, en cuarto) que se conserva en la biblioteca del Conservatorio de Música de San Pietro a Majella de Nápoles, donde se describe esta obra como procedente del oratorio Il Ritorno di Tobia (1774-1775) e impresa en París, $1827 \mathrm{c}$.

Por su parte, la partitura impresa conservada en el Real Colegio-Seminario de Corpus Christi de Valencia está concebida para Soprano, Contralto, Tenor, Bajo, y piano. El impreso perteneció a Vicente Ripollés ${ }^{104}$, quien, en 1939, lo depositó en el archivo como donación.

102 Georg Carl Zulehner (*1770; †1841), que es aquí quien realiza la adaptación de la citada obra de Joseph Haydn, y de quien sabemos que adaptó además para pianoforte (Bonn, Nikolaus Simrock, 1816c) la Missa Sancti Bernardi von Offida del compositor de Rohrau "Heiligmesse", compuesta en 1796 (Hob.XXII:10) para cuatro voces solistas, coro y orquesta, se destacó en su tiempo como editor, arreglista y realizador de reducciones a partir de obras de otros compositores coetáneos suyos. Según H. C. Colles, cobró cierta notoriedad en vida como recopilador de varias Misas que él adjudicó pública, aunque erróneamente, a Mozart. (Vid.: Colles, H. C., ed.: Grove's Dictionary of Music and Musicians. $3^{a}$ edición, en 5 vols. Londres, Macmillan, 1929, vol.V, p. 790). Entre las producciones de G. C. Zulehner que he podido localizar, destacan numerosas ediciones de composiciones de Beethoven, todas ellas realizadas en Maguncia (fundamentalmente, sonatas y algunas bagatelas para pianoforte; diversos tríos, organizados en diferentes formaciones; así como tres cuartetos del Op.59 y una de sus sinfonías). También realizó algunas reducciones de obras de Mozart, entre las que cabe mencionar su reducción de "Las bodas de Fígaro" para pianoforte y violín impresa en Leipzig por Friedrich Hofmeister, o la reducción para pianoforte del "Don Giovanni” editada en Maguncia por Bernhard Schott en 1793. Otros trabajos suyos incluyen la revisión de "El cazador furtivo" de Weber (editada en Maguncia por la casa Schott hacia 1830), las ediciones de un "Victimae paschali" vocal con bajo cifrado de Jommelli, o de "La vestal" de Spontini (publicada en Rheingau), algunas reducciones y arreglos a partir de óperas de Weigl que fueron publicadas en Bonn por Nikolaus Simrock o en Maguncia por Bernhard Schott, entre un larguísimo elenco de ediciones y arreglos de obras de otros muchos autores, como Vincenzo Righini (*1756; †1812), Peter von Winter $(* 1754 ; \dagger 1825)$, Johann Ernst Eberlin $(* 1702 ; \dagger 1762)$, Frantisek Jan Stiastny $(* 1764 c ; \uparrow 1826 p)$, o N. Jorg.

103 "INSANAE ET VANAE CURAE / MOTETE DE HAYDN. / Arreglado para el Pianoforte por ZULEHNER. / En París, en el Almacén de música de Iglesia y de Educación musical. / NICOU-CHORON et CANAUX. Calle S. ta Appoline 15 / Precio 5 francos".

104 Recuérdese que hemos visto ya a Vicente Ripollés Pérez (*Castellón, 20.11.1867; †Rocafort —Valencia—, 19.03.1943), como maestro de capilla del Real Colegio-Seminario de Corpus Christi de Valencia (entre el 06.07.1895 y el 28.08.1902), y más tarde (desde 1927 hasta su muerte) como canónigo de la catedral de la misma ciudad, con motivo de su legado al archivo del Patriarca en el año 1939 de un impreso con el ofertorio de Michael Haydn titulado Domine Deus salutis meae. Realizó trabajos musicológicos, dando a conocer en su tiempo buena parte de la música histórica valenciana (v.g., en su volumen titulado Músicos castellanenses - Castellón, Sociedad Castellonense de Cultura, 1935- o en su magnífico libro titulado El villancico i la cantata del segle XVIII a València. Barcelona, Institut d'Estudis Catalans - Biblioteca de Catalunya, 1935). Muy implicado en los nuevos cambios y corrientes a los que se veía sometida la música religiosa de su tiempo, participó en algunos Congresos Nacionales de Música Sagrada (Valladolid, Sevilla, Barcelona y Vitoria) y, a juzgar por el interesante legado que donó al Colegio del Patriarca, contribuyó poderosamente a la difusión de la música de los clásicos vieneses en ambientes valencianos, llegando a recopilar, por ejemplo, una considerable colección de obras de Joseph Haydn. [Cfr.: Climent, José: "Ripollés Pérez, Vicente", en Diccionario de la Música Española e Hispanoamericana. Madrid, sGAe, 2002, vol. 9, pp. 208-209. Vid. también: -ID.: La Catedral de Valencia devenir musical en el siglo XX. "Estudios Musicológicos, Núm. 4”, 2005, pp. 22-24.] 
La fuente valenciana no se halla referenciada en el catálogo temático de Anthony van Hoboken, como tampoco la copia manuscrita conservada en el Archivo de Música de la Catedral de Tui (La Coruña) ${ }^{105}$.

\section{Missa in Angustiis "Nelsonmesse"}

Joseph Haydn compuso la Missa in Angustiis "Nelsonmesse" (más conocida como "Misa Nelson") ${ }^{106}$ (Hob.XXII:11), en Re menor, en 1798. La obra puede consultarse en el tomo de la edición completa de sus obras, XXIII/3 [pp.1-139], publicado por el Joseph Haydn-Institut de Colonia bajo la dirección de Georg Feder, editado por Günther Thomas e impreso en 1965 en la editorial G. Henle de Munich.

De esta composición hay copia manuscrita — del guión y de las partichelas- en el archivo de la Catedral de Valencia, bajo la signatura 154/1. En la cubierta del guión, que incluye un sello que dice "Archivo metropolitano Valencia - 2359", se lee:

"Missa Imperial / a 2 Coros / y Orquesta / Del Sôr Haydn. / 4. Violines, 1. viola, 1. Flauta, 2 Clarinet $^{\mathrm{i}}, 2$ tromp. ${ }^{\mathrm{s}}$, / 1. Fagot, 1. Clarín, y 3. Bajos. / 5 Voces de primer Coro, y 4. del Segundo con S. duplicada / 28 Pap $^{\text {es }}$ y el Guión 29. / y la Cubierta aparte."107.

En cuanto a las partichelas manuscritas conservadas en la Catedral de Valencia, - de 21,5 x 31,0 cm.—, son las siguientes: Coro 1: S, A, T, B; Coro 2: S, A (2x), T (4x), B (3x); vl 1 (3x), 2 (3x), vla, "Acomp ${ }^{\text {to }}$. Basso Violoncelo" (3x; con indicaciones también para "violón”); fl, ob 1, 2, cl 1, 2, fag; cor (in D) 1, 2, "clarín", “trombones", "figle"; org.oblig (realizado); timp (in D-A); "guión para regir". Tanto la copia manuscrita del guión, como la copia manuscrita de las partichelas, podrían datarse desde mediados del siglo XIX, hasta la década de 1890, aproximadamente.

De la orquestación empleada originalmente por el compositor, sólo faltan en la fuente catedralicia valentina las trompetas 2 y 3; en contraposición, se añaden algunas partes instrumentales, obviamente imposibles en época de Haydn, como por ejemplo el figle, que nos da cuenta del avance de las

105 El catálogo de Hoboken (op. cit.) menciona copias en Austria (en nueve archivos y bibliotecas), Alemania (dos), República Checa (dos), Hungría (una), y Suecia (una). Para las copias españolas citadas, véase: Trillo, Joan; y VILLANUEVA, Carlos: La Música en la Catedral de Tui. La Coruña, Diputación de La Coruña, 1987, p.398; Curment, José: Fondos Musicales de la Región Valenciana II, Real Colegio de Corpus Christi, Patriarca. Valencia, Instituto de Musicología, Institución Alfonso el Magnánimo, Diputación Provincial de Valencia, 1984, p. 405.

106 En realidad, esta Misa "in angustiis" tendría una traducción equivalente a algo así como "Misa en apuros", ya que se concibe como una Misa en o para los tiempos "angustiosos", de miedo y necesidad.

107 El sobrenombre de "Imperial Mass" (Misa Imperial) data de mediados del siglo XIX y fue utilizado con frecuencia en países de habla inglesa para referirse a la Misa en Re menor ("Nelson") MISSA IN ANGUSTIIS (Hob.XXII:11). Este sobrenombre surgió por la creencia equivocada de que la Misa había sido compuesta para la coronación del emperador de Austria, falsedad que también dio lugar al sobrenombre "Coronation Mass" ("Misa de la Coronación"). Véase: - WYN JONES, David: Oxford Composer Companions: Haydn. Nueva York, Oxford University Press, 2002, p. 167. 
modas. En este sentido, repárese en la concepción plenamente decimonónica del juego de partichelas, "para gran orquesta" podríamos decir, con inclusión de timbales, órgano, guión para regir y unos metales bastante abultados, a base de trompas, trombones, clarín y figle, si no agrupados todavía en "familia", sí al menos cubriendo el máximo de espectro tímbrico-tesitural posible. Por otra parte, dicha fuente valenciana no se halla mencionada en el catálogo temático de Anthony van Hoboken, ni en las publicaciones del Joseph Haydn-Institut de Colonia, al igual que sucede con otras copias manuscritas conservadas en España, que he podido localizar en el Archivo de Palacio en Madrid, o con sendas copias de la misma obra en el Archivo de Música de las Catedrales de Zaragoza, donde se la identifica como "Misa Imperial" 108 , así como con otras copias conservadas en Latinoamérica, ubicadas concretamente en los archivos de las catedrales Metropolitana de México, de Santiago de Chile, y en la escuela de música "José Ángel Lamas” de Caracas (Venezuela) ${ }^{109}$.

\section{3. (Grosses) Te Deum ${ }^{110}$}

Joseph Haydn compuso, aproximadamente en 1799-1800, el Te Deum für die Kaiserin Marie Therese ("Te Deum para la emperatriz María Teresa") (Hob.XXIIIc:2), en Do Mayor. La obra ha sido editada por H. C. Robbins Landon e impresa en 1959 en la editorial Ludwig Doblinger de Viena ${ }^{111}$.

En el archivo del Real Colegio-Seminario de Corpus Christi de Valencia, con la signatura H 8/3, encontramos partichelas impresas de esta misma obra (falta la partichela de la trompeta $3^{\text {a }}$ ) las cuales anotan el correspondiente reparto en lengua italiana, sin que nos haya sido todavía posible conocer con exactitud el nombre de su posible editor, seguramente francés a juzgar por su número de plancha: “D. et C. No. 2242".

Estas partichelas impresas, de 33,8 x 26,0 cm., aparecieron envueltas en un papel fino -en cuya parte superior derecha se ha pegado una etiqueta con el número " 23 ”- y recogen la siguiente

108 Signaturas E: Zac, D-235/1974 (un libro y partichelas, todo impreso, con acompañamiento de órgano, por V. Novello [que se corresponde con la Misa Nr.3 en la colección de este último]) y E: Zac, D-217/1780, respectivamente. [Agradezco la intervención al Dr. Antonio Ezquerro].

109 El catálogo de Hoboken (op. cit.) menciona copias en Austria (en dieciséis archivos y bibliotecas), Alemania (cinco), República Checa (cuatro), Italia (dos), Bélgica (una), Gran Bretaña (una), Hungría (una), Croacia (una), y Eslovaquia (una). Para las copias españolas citadas, véase: García Marcellán, José: Catálogo del Archivo de música de la Real Capilla de Palacio. Madrid, Editorial de Patrimonio Nacional, s.f., p. 80. Cument, José: Fondos Musicales de la Región Valenciana I. Catedral Metropolitana de Valencia. Valencia, Institución Alfonso el Magnánimo, Diputación Provincial de Valencia, 1979, p. 206. PeRIS Lacasa, José: Catálogo del Archivo de Música del Palacio Real de Madrid. Madrid, Patrimonio Nacional, 1993. Para las copias en Latinoamérica, véase: STEVEnson, Robert: "Haydn's Iberian World Connections", en Inter-American Music Review, 4 (1982), pp. 19, 24 y 26.

110 El Te Deum für die Kaiserin Marie Therese (“Te Deum para la emperatriz Maria Teresa") no ha sido editado todavía por el Joseph Haydn-Institut de Colonia.

111 La edición de H. C. Robbins Landon incluye tres trombones (alto, tenor y bajo), anotados en pauta con un tamaño menor al habitual en el resto de la partitura. Sin embargo, D. Wyn Jones no menciona tales instrumentos en su estudio (WYN JONES, David: Oxford Composer Companions: Haydn. Nueva York, Oxford University Press, [2002], p. 415). 
instrumentación: "Soprano", "Alto", "Tenore", "Basso"; "Violino 1 10", "Violino 2do", "Viola", "Basso et Violoncello"; "Flauto", "Oboe ò Clarinetto 1 ${ }^{\mathrm{mo}}$ ", "Oboe ò Clarinetto 2do", "Fagotti"; "Corno $1^{\mathrm{mo}}$ in C", "Corno $2^{\text {do }}$ in C", "Clarino $1^{\text {o }}$ in C", "Clarino 2. in C"; "Timpani in C-G"; "Organo".

Si hubiera que aventurar una datación para esta fuente, podríamos fijarla hacia el primer tercio del siglo XIX, aproximadamente.

En cualquier caso, el documento valenciano del archivo de la Iglesia del Patriarca no se halla referenciado en el catálogo temático de Hoboken. Tampoco aparece en dicho catálogo temático alusión alguna a otras copias manuscritas conservadas en España, como las que he podido localizar ubicadas en el Monasterio de Montserrat, o en los archivos de las catedrales de Santiago de Compostela, de Valladolid y de Zaragoza, así como otra copia, en este caso latinoamericana, conservada en la escuela de música "José Ángel Lamas" de Caracas (Venezuela)"

\section{4. "Schöpfungsmesse"}

En el mismo libro impreso conservado en el Archivo de Música del Real Colegio-Seminario de Corpus Christi, a continuación del Sanctus et Benedictus de la Misa en Do menor (Hob.XXII:c1) (que analizaremos en el apartado 17 de este mismo artículo, y a cuya referencia y descripción documental remito), aparece impreso otro Sanctus et Benedictus — sin que conste a qué Misa podría pertenecer, ni el nombre de su compositor-, el cual forma igualmente parte de la colección La Lire Sacrée $e^{113}$.

En el reverso de la cubierta se lee: "BIBLIOTECA / del M. I. Sr. D. Vicente Ripollés Pérez / Canónigo de la Catedral y antiguo Maestro / de Capilla en la de este R. Colegio de / Corpus Christi de Valencia / (†19 marzo 1943) / Legada por el mismo a este R. Colegio / AÑO 1939”.

No obstante, cotejando íncipits musicales, he podido identificar dicho impreso "anónimo" como el Sanctus et Benedictus pertenecientes a la "Schöpfungsmesse" ("Misa de La Creación”) (Hob.

112 El catálogo de Hoboken (op. cit.) menciona copias en Austria (en trece archivos y bibliotecas), Alemania (cinco), República Checa (dos), Gran Bretaña (una), Hungría (una), e Italia (una). Para las copias españolas citadas, véase: CLIMENT, José: Fondos Musicales de la Región Valenciana II, Real Colegio de Corpus Christi, Patriarca. Valencia, Instituto de Musicología, Institución Alfonso el Magnánimo, Diputación Provincial de Valencia, 1984, p. 406; LóPez CALo, José: Catálogo Musical del Archivo de la Santa Iglesia Catedral de Santiago. Cuenca, Ediciones del Instituto de Música Religiosa, 1972, p. 315; Fichas catalográficas del Archivo de Música del Monasterio de Montserrat, y del Archivo de Música de la Catedral de Valladolid, inéditas (conservadas en los ficheros de la Redacción central de RISM-España en Barcelona). La fuente zaragozana, E: Zac, D-153/1264 señala en la portada de su partitura "Orgue ou Piano par N. Carbonel", y se corresponde por tanto con la referencia dada por Hoboken (Porro, 1805): "Musique Sacrée, No 5. Te Deum par J. Haydn à Grand Orchestre Partition et Parties. Traduction de P. Porro, Orgue ou Piano par N. Carbonel. Rue Beaurepaire No 16 (luego, Rue J. J. Rousseau $\mathrm{N}^{\circ} 14$ [1825]), con texto en latín y francés. (Agradezco el dato de la fuente zaragozana al Dr. Antonio Ezquerro). Para la copia latinoamericana, véase: Stevenson, Robert: "Haydn's Iberian World Connections", en Inter-American Music Review, 4 (1982), p. 19.

113 "LA LIRE SACRÉE Catalogue des Morceaux Publié à Paris chez Colombier, Sucé de A. Petit, Rue Vivienne, 6, au coin du Passage Vivienne". [LA LIRA SAGRADA Catálogo de Fragmentos Publicado en París por Colombier, Sucesor de A. Petit, Calle Vivienne, 6, a la vuelta del Pasaje Vivienne]. Véase la nota 4. 
XXII:13), compuesta por Joseph Haydn en el año 1801. En conclusión, se trata de una partitura impresa en París por Canaux, de 33,2 x 25,3 cm., que pertenecía a la colección editorial titulada La Lyre Sacrée (con una numeración entre las páginas 39-50), la cual presenta un número de plancha (“C. C. 424”) que corresponde al editor Canaux (a juzgar por el sello que lleva estampado en formato oval enmarcando su dirección postal):

“21 R. DES FOSSÉS MONTMARTRE / A PARIS / [y en el centro del sello, imitando la firma autógrafa del almacenista-propietario, a manera de autentificación del impreso, y rubricado:] Canaux".

Esta edición se publicó entre julio de 1840 y abril de $1842^{114}$.

El título, en el encabezamiento de la página 39 dice: "SANCTUS" y en la página 43 dice: "BENEDICTUS".

Hay que considerar que el impreso francés se trata de un arreglo o adaptación para voces solistas, Coro y el órgano (para conseguir acaso una mayor e ingenua divulgación de estas dos secciones de la Misa, o incluso tal vez con alguna resolución comercial), a partir de la partitura que Joseph Haydn compuso originalmente para el tradicional coro SATB y cuatro voces solistas (ampliadas a seis momentáneamente en los compases 307-312 del Gloria), orquesta y órgano, distribución esta última que sí respeta la edición alemana.

La obra puede consultarse en el tomo de la edición completa de sus obras, XXIII/4 [pp.1-203], publicado por el Joseph Haydn-Institut de Colonia bajo la dirección de Georg Feder, editado por Irmgard Becker-Glauch e impreso en 1967 en la editorial G. Henle de Munich. En concreto, el Sanctus comprende las páginas 131 a 145, y el Benedictus las páginas 146 a 170 de la edición alemana. La identificación de este Sanctus et Benedictus perteneciente a la Schöpfungsmesse de Joseph Haydn no aparece por tanto reflejada en el catálogo disponible de este archivo, a cargo de José Climent ${ }^{115}$. Sin duda alguna, el catálogo de Anthony van Hoboken no menciona esta fuente documental — partitura impresa- hallada en Valencia ${ }^{116}$, como tampoco aparece en la obra editada por el Joseph HaydnInstitut de Colonia. Por otro lado, he podido localizar alguna otra fuente conservada en España, aunque

114 "En junio de 1840, Toussaint Canaux adquirió, por el sistema de venta organizada después de la quiebra del editor Delahaute, todas las obras compradas de La Creación de Haydn que Delahaute había publicado. A la vista de las indicaciones " $3^{\mathrm{e}}$ Année.", "3e Livraison.", este SANCTUS y BENEDICTUS ha sido publicado en el marco de la colección "Bibliothèque de l'organiste". Generalmente, para esas colecciones, los editores se servían de series de números - lo que dificulta la datación a partir de números de plancha-. Sin embargo, gracias a la dirección "Rue des Fossés Montmartre" y al hecho de que la compra del lote procedente de los fondos Delahaute tuvo lugar en 1840, y que en abril de 1842 Canaux se había mudado al n ${ }^{\circ} 15$ calle Sainte-Apolline, esta edición fue publicada entre julio de 1840 y abril de 1842 ”. [Agradezco esta información a la profesora Anik Devriès-Lesure, en su carta del 25 de julio de 2005].

115 Climent, José: Fondos Musicales de la Región Valenciana, II. Real Colegio de Corpus Christi; Patriarca. Valencia, Instituto de Musicología, Institución Alfonso el Magnánimo, Diputación Provincial de Valencia, 1984.

116 Según el catálogo temático de nuestro compositor, se encuentran ejemplares en Austria (en catorce localidades), Alemania (cinco), Italia (dos) y la antigua Checoslovaquia (tres). (Véase: HoBoKen, Anthony van: op cit., pp. 105-106). 
sin indicación explícita que pueda hacernos identificar los documentos localizados con esta misma composición ${ }^{117}$.

\section{Sancta Maria}

El Joseph Haydn-Institut de Colonia, solamente conoce esta obra a través de un manuscrito con las partes de las voces en la Bibliothèque Royale Albert 1.er (Boulevard de l'Empereur 4, B1000 Bruxelles; signatura: Mus. Ms. 1014/1). No se tiene conocimiento de edición alguna de esta obra, y se estima, además, que no llegará a publicarse en la edición completa de las obras de Joseph Haydn $^{118}$. Las partichelas de Bruselas, datables hacia finales del siglo XIX y aun acaso a comienzos del xx, únicamente recogen las partes para "1º Soprano", "2ºprano" y " $3^{\circ}$ Soprano", y no aparece junto a ellas acompañamiento alguno.

Por contraposición, en el archivo de la Catedral de Valencia hay una copia manuscrita de la partitura (datable a finales del siglo XIX), en la tonalidad de Sol Mayor, y encabezada como "Motete", con la signatura 153/6, cuyo título dice:

\section{"Sancta María" Motete a 3 de Haydn.}

El material custodiado contiene los siguientes efectivos: "Tiple o Tenor 10", "Tiple o Tenor

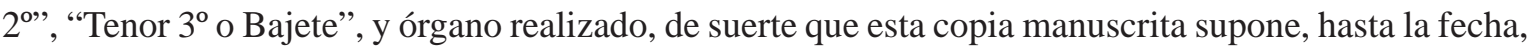
la única completa conocida, a falta de verificar o no la autenticidad de la autoría de Joseph Haydn. Por lo demás, tanto la copia belga como la valenciana, presentan algunos detalles de copia coincidentes

117 Es el caso, por ejemplo, del Archivo de Música de las Catedrales de Zaragoza, donde se encuentra una "Misa Solemne" también en SibM y que se inicia en compás de 3/4, de la cual se conserva partitura impresa con acompañamiento de órgano (por V. Novello), así como manuscrito (con signatura E: Zac, D-226/1923) [agradezco la información al Dr. Antonio Ezquerro]. Algo parecido sucede en el Santuario de Aránzazu, en cuyo catálogo de su archivo musical se menciona apenas una Misa a 4 - incompleta - en "SibM", que, aunque bien pudiera coincidir con la nuestra (a juzgar por su reparto vocal e instrumental), únicamente a partir de los datos suministrados por el citado catálogo publicado que he podido manejar, no podemos identificar plenamente con la composición objeto de nuestro interés. Cfr.: BAGÜÉs ERriondo, Jon: Catálogo del antiguo Archivo Musical del Santuario de Aránzazu. [San Sebastián], Caja de Ahorros Provincial de Guipúzcoa, 1979, p. 124: "Ms.191". Un caso similar lo constituye una "Misa en Si bemol" en partitura del siglo XIx impresa para voces y piano (Leipzig, Peters), que se localiza en la Catedral de Santiago de Compostela. Vid.: LóPez-Calo, José: Catálogo Musical del Archivo de la Santa Iglesia Catedral de Santiago de Compostela. Cuenca, Instituto de Música Religiosa de la Diputación, 1972, p. 315: “2242”. En la Catedral de Burgos encontramos también una "Misa a 8", aunque sin indicación de tonalidad [?]: Vid.: ID.: La música en la Catedral de Burgos. Vol. II. Catálogo del Archivo de Música (II). Burgos, Caja de Ahorros del Círculo Católico, 1995, p. 288: n de registro "1.646", signatura "108/8". Y también se registra una Misa en SibM de Joseph Haydn en: Liaño Pedreira, María Dolores: Catálogo de Partituras del Archivo Canuto Berea en la Biblioteca de la Diputación de A Coruña. Tomo I. A Coruña, Diputación Provincial de A Coruña, 1998, p. 672: seguramente, la referencia dada ha errado la traducción, pues el original impreso dice estar en "B dur" (= SibM), y en cambio, se ha traducido como "si mayor" (!); se trata de una reducción para piano (61 páginas) editada en Leipzig por C. F. Peters en el siglo XIX.

118 Agradezco esta información al Dr. Robert von Zahn, del Joseph Haydn-Institut, de Colonia, en su carta del 20 de febrero de 2002. 
(indicaciones aisladas de "tempos", como por ejemplo "Poco più animato", "Più lento"...), así como otros que las diferencian ( $E$ : $V A c$, "And.te"; $B: B r$, "Andantino"; algunos matices expresivos, más abundantes en $B: B r$, del tipo reguladores, indicaciones — sólo en $B: B r$ - como "dolce", "calando", "espressivo", "morendo", “1 tempo"...). En todo caso, las partes intervinientes se corresponden entre sí del siguiente modo:

\begin{tabular}{|c|c|c|}
\hline E: VAc & & $\underline{\mathbf{B}: \mathbf{B r}^{119}}$ \\
\hline $\mathrm{S}(\mathrm{T} 1)$ & $=$ & S 1 \\
\hline$S(T$ 2) & $=$ & S 2 \\
\hline $\mathrm{T}$ (Bar) & $=$ & S 3 \\
\hline
\end{tabular}

Del conjunto, cotejadas las dos fuentes, podría inferirse no obstante que se tiene la impresión de que ambas copias manuscritas hubieran podido extraerse de algún tronco común, acaso un ejemplar impreso hoy desaparecido o en el que todavía no haya reparado la investigación musicológica (?). En cuanto a su posible datación, ésta podría fijarse, aproximadamente, entre 1880 y 1900. Y entretanto, la copia valenciana contaría con una especial significación y valor, habida cuenta de tratarse del único ejemplar dispuesto en partitura, y supuestamente dotado de todas las partes vocales e instrumentales de la composición ${ }^{120}$.

\section{Ave, verum corpus}

Esta obra se encuentra en una partitura manuscrita veneciana atribuida a Joseph Haydn (Biblioteca Nazionale Marciana, Piazzetta San Marco 7, I-30124 Venezia; signatura: Ms. 11022 / It. IV-1284), si bien existe una edición impresa por Durand-Schoenewerk \& Cie como Tomo I de "Échos du monde religieux" (el "Ave, verum corpus" comienza en la p. 68) en fragmentos de piano. Tampoco está previsto publicar esta composición en la edición completa de las obras de Joseph Haydn ${ }^{121}$.

En el archivo de la Catedral de Segorbe hay un ejemplar impreso de esta obra, en Fa Mayor, con la signatura 33/9 para Voz, órgano o piano. Por otra parte, la pieza manuscrita conservada en

119 Ambas copias difieren en lo fundamental, en lo referido exclusivamente a las partes vocales, únicamente en la disposición de las notas del acorde final de Sol Mayor, así como en las notas correspondientes al segundo tiempo del compás 27 (la obra se anota en compás de 12/8), parte del T (Bar) (anotado en clave de Fa en cuarta línea en E: VAc) y del S 3 (anotado en clave de Sol en $B: B r$ ).

120 No obstante, conviene precisar que en el Archivo de Música de las Catedrales de Zaragoza se conserva también un Motete a la Virgen "Sancta Maria" con presencia de órgano, en Sol Mayor y compás de 12/8, coincidente por tanto con la copia manuscrita de la Catedral de Valencia, y que nos daría cuenta de la "circulación" de la obra atribuida a Joseph Haydn por toda España. [Agradezco la información al Dr. Antonio Ezquerro]. de 2002.

121 Agradezco esta información al Dr. Robert von Zahn, del Joseph Haydn-Institut de Colonia, en su carta del 20 de febrero 
Venecia, con el mismo reparto vocal e instrumental, no presenta síntomas aparentes de tratarse de un documento anterior al impreso de Segorbe.

El impreso segorbino del Ave, verum corpus, de 26,4 x $18 \mathrm{~cm}$, no ha conservado su portada o cubierta, lo que, en principio, dificultaba la identificación de su posible casa editorial y lugar de edición $^{122}$. No obstante, tras comprobar que el impreso se anotaba en castellano — síntoma evidente de que debía tratarse de una publicación española—, y que incluía como número de plancha la referencia “C.S. 228.”, pude identificar, gracias a los datos mencionados, las iniciales del citado impreso como correspondientes al editor madrileño Carlos Saco del Valle, activo en Madrid —por cuanto se sabe hasta la fecha - entre los años 1875 y 1893 . Hasta el momento, es muy poco todavía lo que se conoce sobre este editor, al parecer más ligado a su faceta como almacenista de música e instrumentos (tenía venta de pianos), que propiamente a su labor editorial ${ }^{123}$.

Sea como fuere, esta obra se corresponde con una referencia existente en el inventario del archivo musical de Segorbe, del año 1929, en la que se menciona "4 Cuadernos, Cuartetos... Haydn"124, propiedad del presbítero segorbino Vicente Perpiñán Górriz (*Segorbe, 1884; †Id., 1950) ${ }^{125}$. De hecho, este impreso bien pudo haber pasado a los fondos del archivo catedralicio junto al legado que realizaron a esta catedral los sobrinos de Vicente Perpiñán a su muerte, en el año 1950.

122 En el Archivo de Música de las Catedrales de Zaragoza se encuentran asimismo dos juegos documentales atribuidos a Joseph Haydn sobre el texto del motete al Santísimo "Ave, verum corpus", aunque no parecen coincidir con la copia impresa de Segorbe; se trata de E: Zac, D-356/4204 (una partitura y partichelas manuscritas, anotada en MibM y que comienza en compás de 3/4); y E: Zac, D-292/2789 (una partitura impresa, ya de comienzos del siglo xx, anotada en SibM y 3/4). (Agradezco el dato al Dr. Antonio Ezquerro).

123 Según C. J. Gosálvez, estuvo relacionado comercialmente con el editor, compositor y pianista Nicolás Toledo (quien, desde 1873, comenzó a imprimir música con el novedoso sistema fotolitográfico), y fue antecesor del último maestro de la Real Capilla española — con Alfonso XIII-, Arturo Saco del Valle. Su establecimiento madrileño cambió varias veces de dirección (1875c, en la calle Silva 44; 1876-1881, en la calle Jacometrezo 37 y 39 —pianos—; 1880-1882, en Jacometrezo 65 —almacén de música—; 1882, en la calle Peligros 9 — pianos_; 1882-1885, en la calle Infantas; y 1884-1893, en la calle Arenal 20, en el mismo local donde veinte años atrás se ubicara el establecimiento de Antonio Romero y, tras Saco del Valle, sucesivamente, el de la Sociedad de Autores y el almacén y editorial de Fuentes y Asenjo). [Todos estos datos tomados de: Gosálvez LaRA, Carlos José: La edición musical española hasta 1936. Madrid, AEDOM, Colección de Monografías, n 1, 1995, p. 178].

124 Agradezco esta información al profesor Magín Arroyas Serrano.

125 Vicente Perpiñán Górriz, natural de Segorbe (donde fue discípulo de su tío José, y más tarde, ya en Valencia, de José Mª Fayós y José Ma Úbeda), se ordenó sacerdote el 09.05.1909, posesionándose previamente de la plaza de organista de la Catedral de Albarracín (Teruel), donde estuvo hasta el 1 de septiembre de 1913, en que obtuvo el beneficio de maestro de capilla y organista de la Catedral de Orihuela (Alicante) que estaba vacante. Permaneció en Orihuela hasta el 15 de diciembre de 1931, cuando consta documentalmente que se nombró ya un tribunal técnico y comisión del cabildo para la oposición a maestro de capilla, por vacante de Vicente Perpiñán. [Agradezco esta última información a Agustín Sánchez Manzanares, sacerdote de la diócesis de OrihuelaAlicante]. Al parecer, tras renunciar a su cargo de Orihuela, pasó a la parroquia de San Agustín, de Valencia, donde estuvo como beneficiado organista hasta el año 1950, cuando, tras opositar y lograr la organistía de la Catedral de Segorbe, murió en su ciudad natal justo el día anterior a tomar posesión de su nuevo cargo. Sobre V. Perpiñán, véase también: Climent, José: Fondos Musicales de la Región Valenciana, III. Catedral de Segorbe. Segorbe, Publicaciones de la Caja de Ahorros y Monte de Piedad de Segorbe, 1984, pp. 211-214. ID.: "Perpiñán. 2. Perpiñán Górriz, Vicente", en Diccionario de la Música Española e Hispanoamericana. Madrid, SGAE, 2001, vol. 8, p. 723. [Agradezco la información a propósito del "legado Perpiñán" a Pedro Saborit Badenes, deán y archivero de la Catedral de Segorbe]. 


\section{Sanctus et Benedictus extrait de la $10^{a}$ messe d'Haydn}

Según parece, esta composición no figura ni en el índice de obras autorizadas por Joseph Haydn, ni tampoco se encuentran, hasta hoy, datos documentados que la conecten directamente con nuestro compositor. No obstante, y con carácter general, esta obra — por consiguiente de autoría más que dudosa - ${ }^{126}$, podría identificarse con una transcripción para cuatro voces mixtas y órgano de la Misa en Do menor (Messe in c-Moll) (Hob.XXII:c1), hecha — manuscrita— por Vincent Novello (*06.09.1781; $† 09.08 .1861)$ en la década de 1820 y también editada por él.

Por su parte, el Joseph Haydn-Institut de Colonia no tiene constancia de la existencia de otra edición de esta obra, ni cuenta con datos de su posible reparto original, desconociendo por otro lado el nombre de su compositor auténtico. De modo que, a la luz de lo anterior, no está previsto publicar esta composición en la edición completa de las obras de Joseph Haydn ${ }^{127}$.

Por lo demás, he podido averiguar que esta obra se encuentra, además, en una colección manuscrita conservada en la British Library de Londres (con la signatura Add. MS 65400-65407), copiada —es decir, de la mano de este italiano afincado en Inglaterra - y encuadernada por Vincent Novello en el año 1825, la cual consta de dos folios preliminares más otros 61 folios numerados (de 24,2 x 30,0 cm.). Concretamente, este Sanctus et Benedictus se corresponde, dentro de la citada colección manuscrita, con la signatura de la Biblioteca Británica Add. MS 65404, a lo que podríamos todavía añadir el número “355/9”, correspondiente al número de cubierta de Vincent Novello para su propia biblioteca particular ${ }^{128}$.

Este último manuscrito (Add. MS 65404), que supone el volumen XXIII de la "Colección Novello", contiene las partituras para orquesta de dos Misas, a saber: la Misa en Do (Hob.XXII:c1) y la Misa en Fa (Hob.XXII:1). De dichas Misas, la primera, que es objeto de nuestro interés, fue escrita por Edouardo Olmeda en su mayor parte, aunque con el "Benedictus" escrito por el propio Vincent Novello (mientras que la Misa en Fa, fue escrita por Vincent Novello en su totalidad) ${ }^{129}$. Estas Misas de Joseph Haydn con acompañamiento de órgano, serían publicadas por William Galloway en 1823-1825, en edición a cargo del propio Vincent Novello, como números 10 y 11 (según Hoboken) ${ }^{130}$. Más tarde,

126 Según Anthony van Hoboken (op. cit.), esta Misa en Do, es de dudosa autenticidad.

127 Agradezco estas informaciones al Dr. Robert von Zahn, del Joseph Haydn-Institut de Colonia, en su carta del 20 de febrero de 2002.

128 De otro lado, los responsables de las colecciones de música de la British Library tampoco disponen de información sobre las fuentes a partir de las cuales pudo haber sido copiado este manuscrito, ateniéndose a que, según Hoboken, esta Misa en Do menor es de dudosa autenticidad. (Agradezco la información suministrada por el Dr. J. Clements —en su carta de 08.12.2004— y el Sr. Robert Balchin, Conservador de las Colecciones de Música, —en su carta de 02.02.2005—, ambos de la British Library londinense). En cualquier caso, la portadilla de la obra copiada por Novello, que se conserva en la Biblioteca Británica, reza así: "Haydn's Mass / commencing in / C-Minor / No 10. / For 2 Violins, Tenor \& Bass - 2 Flutes 2 Horns, 4 Voices and Organ. / From

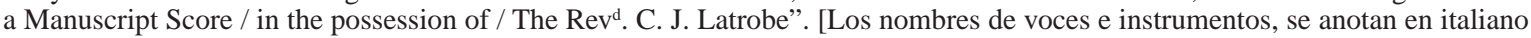
en la armadura inicial de la composición].

129 Según Hoboken, a diferencia de la dudosa Misa en Do de nuestro interés, la Misa en Fa es una obra genuina de Joseph Haydn, la cual habría compuesto hacia el año 1750.

130 Новокеn, Anthony van: Joseph Haydn. Thematisch-bibliographisches Werkverzeichnis. Band II: Vokalwerke, pp. 71, 111 y 117. Band III: Register Addenda und Corrigenda, p. 59. [Según Hoboken, la Misa número $9=$ XXII:C1, la Misa número 10 = XXII:c1, y la Misa número 11=XXII:1]. 
—después de 1828 —, se publicaría esta misma transcripción con el hijo de Vincent Novello, Joseph Alfred (*12.08.1810; †16.07.1896).

En este manuscrito de la British Library, en la primera hoja de papel pautado dice:

"Haydn's Mass / commencing in / C - Minor / $\mathrm{n}^{\circ}=10$. / For 2 Violins, Tenor \& Bass -2 Flutes, 2 Horns, 4 Voices and Organ. / From a Manuscript Score / in the possession of / The Rev ${ }^{\mathrm{d}}$ - C. I. Latrobe".

Al final de la partitura se anota la siguiente inscripción:

"Copied for the / illustrious / Signor Vincenzo Novello / by / Edouardo Olmeda J[an]uar[y] 17-1825"

En la partitura, las cuatro voces del coro no están siempre escritas. Sólo aparecen en el Kyrie -y no siempre-, y en el Benedictus. Tras la copia manuscrita de las partes vocales del Kyrie -anotado desde el comienzo, aunque al parecer, sin acabar su copia (terminando el coro además en la dominante, y sin anotar el correspondiente "Christe" y segundo "Kyrie")- prosiguen la cuerda y los vientos durante un extenso pasaje, lo que da a entender que el copista no haya terminado su trabajo, dejando la parte coral sin acabar de anotar.

Por otro lado, conviene recordar que, frente a la copia a cargo de una primera mano de toda la Misa (a cargo de Edouardo Olmeda, que cumple así una función de amanuense para Vincent Novello), se constata un cambio de copista para el Benedictus, realizado por el propio Novello.

En el archivo del Real Colegio-Seminario de Corpus Christi de Valencia se encuentra el impreso, sin signatura, aunque con número de registro 2.587. Este impreso perteneció a Vicente Ripollés, que en 1939 lo depositó como legado (o donación) al archivo colegial. En concreto, se trata de una partitura impresa en París por Canaux, de 35,2 x 27,4 cm., que pertenecía a la colección editorial titulada La Lyre Sacrée (de hecho, en ella se refleja una numeración entre las pp. 53-60), la cual presenta un número de plancha que hay que adscribir al matrimonio editor (o bien, acaso más posiblemente a juzgar por el sello que lleva estampado, a su continuador, el propio Canaux) Nicou-Choron ("N.C. 283"). La datación de este impreso, por tanto, debería fijarse entre los años 1836 y 1842. Su título propio, en el encabezamiento de la página 53 , dice:

"SANCTUS ET BENEDICTUS extrait de la $10^{\mathrm{e}}$. Messe D'HAYDN 1780."131. 
Por otra parte, el impreso valenciano muestra en su primera página (es decir, en la página 53, que haría las veces de portada), dos sellos entintados de caucho. El primero de ellos, en formato oval y con una línea en su perímetro que enmarca su dirección postal, corresponde al editor-almacenista productor del impreso:

“21 R. DES FOSSÉS MONTMARTRE / A PARIS / [y en el centro del sello, imitando la firma autógrafa del almacenista-propietario, a manera de autentificación del impreso, y rubricado:]

$$
\text { Canaux". }
$$

En cuanto al segundo sello mencionado, corresponde a la adquisición y propiedad del impreso por parte del célebre colegio valenciano:

\section{"REAL COLEGIO / DE / CORPUS-CHRISTI / VALENCIA".}

Por lo demás, y como resulta evidente de nuestra relación anterior, el impreso valenciano únicamente incluye el Sanctus (en Do Mayor) y el Benedictus (en Fa Mayor) de esta Misa, que no ha presentado problemas de identificación, pues se relaciona con la Misa número $10=$ XXII:c1, según el catálogo tantas veces citado de Anthony van Hoboken.

En todo caso, el reparto que presenta el impreso conservado en Valencia es el siguiente: "Soprano", "Alto", "Tenor", "Basse"; "orgue". El órgano está realizado. La pieza se anota en Do Mayor, y se inicia en compás de 3/4 y tempo "Adagio". Toda la composición se anota de corrido, sin diferenciar en sistemas o páginas diferentes las diversas secciones de que consta (de modo que el Benedictus prosigue en el mismo sistema de líneas al inmediatamente anterior Sanctus). Compositivamente, se han trabajado de manera diferenciada las siguientes partes:

$1^{\text {a) }}$ Sanctus (Do M, Adagio, 3/4) -

$2^{\mathrm{a}}$ ) Pleni sunt caeli (Do M, Allegro, 2/4) -

$3^{\mathrm{a}}$ ) Benedictus (Fa M, Andante, C).

Y no se ha compuesto el correspondiente "Hosanna" que debería finalizar el Benedictus. Por otro lado, llama la atención la datación que se da a esta composición en el impreso de Nicou-Choron / Canaux conservado en Valencia, de "1780", fechas en torno a las cuales Joseph Haydn compuso asimismo su Sinfonía $\mathrm{n}^{\mathrm{0}}$ 71, la ópera La fedeltà premiata, o año en el que Artaria editó en Viena sus Sonatas para piano $\mathrm{n}^{\mathbf{0}} 20$ y 35-39.

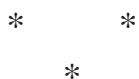


En definitiva, y tras repasar las fuentes documentales de música litúrgica de F. J. Haydn que se conservan en los archivos musicales catedralicios de Valencia, Segorbe y Orihuela, así como en el Real Colegio-Seminario de Corpus Christi de Valencia, queda bien patente la rápida llegada y pronta asunción de la música del compositor de Rohrau por parte de las capillas eclesiásticas valencianas y sus músicos. El gran desconocimiento al respecto que, todavía hoy, padece la musicología hispánica a nivel internacional, así como el enorme interés que las fuentes documentales pueden ofrecer — por su cronología y distribución-, plantean la evidencia de una urgente revisión acerca del impacto de la producción del maestro a nivel internacional, así como la necesidad de ampliar el espectro geográfico - aquí apenas focalizado en cuatro archivos de la Comunidad Valenciana- a otros lugares de la península ibérica e incluso de Latinoamérica, y también el objeto de estudio, ampliándolo, en su conjunto, a los así llamados "clásicos vieneses".

Recibido: 23/06/08

Aceptado: 28/10/08 